OmniaScience

\title{
High involvement work programs (HIWP) measurement model validation and its capacity to predict perceived performance
}

\author{
Amable Juarez-Tarraga ${ }^{1} \mathbb{D}$, Juan A. Marin-Garcia ${ }^{2}$, Cristina Santandreu-Mascarell ${ }^{1}$ \\ ${ }^{1}$ Universitat Politècnica de València, Dept. Organización de Empresas (Spain) \\ ${ }^{2}$ ROGLE-UniversitatPolitècnica de València (Spain) \\ amjua@,omp.upv.es,jamarin@,omp.upv.es, crisanma@,omp.upv.es
}

Received July, 2016

Accepted August, 2016

Versión en español

\section{Abstract}

Purpose: One of the objectives of the work is the validation of a measurement model of the HIWP (High Involvement Work programs) based on Lawler (1986) questionnaire. Our proposal presents a second order composite construct for HIWP, in which the four first-order constructs that characterize the model (Communication, Training, Compensation and Participation) are composite constructs. After addressing the validation of the measurement model, it is also checked the structure model to assess the predictive ability of HIWP on perceived performance in three different samples from different countries.

Design/methodology: To validate the model based on composites, partial least squares (PLSSEM) was used. Data were obtained by researchers who developed the official versions of the questionnaire in English and Castilian.

Findings: Overall, this study contributes to the debate on the relationship HIWP-results, pointing to a possible predictive capacity of Lawler's HIWP model on perceived performance. Our study confirms significant (although low) relationship between the use of HIWP and performance. But nevertheless, part of measurement model has not been fully validated and should be confirmed in future research. 
Research limitations/implications: First, our data come from studies of more than 15 years ago, but to test measurement models, the date of the data is not a significant limitation because we analyzed the relationship between the constructs and were not interested in describing the state of evolution of these practices, but how to measure this relationship. Moreover, we only have data from large companies in both countries so we can not generalize the findings to other contexts.

Originality/value: The findings are important for practitioners and researchers because quantifies the relationship between the use of HIWP and performance in two countries with important cultural differences, and also identifies practices that contribute most to this positive relationship.

Keywords: HRM, Human Resources, Composite model mode B, PLS-SEM, High Involvement Work programs, HIWP

Jel Codes: O15, L25

\section{Introduction}

One of the most important questions within the framework of research on Human Resource Management Systems, and more specifically in relation to the use of High Involvement Work Practices(HIWP), is understanding how they affect the company's results (Becker \& Huselid, 2006; Benson, Young \& Lawler III, 2006; Bowen \& Ostroff, 2004; Huselid \& Becker, 1996) and being able to decipher what has been identified as “the black box" (Jiang, Takeuchi \& Lepak, 2013)

A great deal of research has been done in this field, and several meta-analyses have analyzed the results of previous research. In this regard, we can highlight the works by Combs, Liu, Hall and Ketchen (2006), who evaluated the results of 92 studies on the influence of the application of these programs on business performance; Subramony (2009), who assessed the relationship among three human resource management program packages that make up the AMO (Ability, Motivation and Opportunity) model and business performance in 65 articles; and Jiang, Lepak, Hu and Baer (2012), who an alyzed in a more complex and detailed manner the relationships on different levels between the items and constructs that explain the relationship between the programs in the AMO model and business 
performance in 116 previous articles. These meta-analyses confirm that HIWP positively affect business performance.

However, it should also be pointed out that some researchers have found contradictory results, such as in the case of Cappelli and Neumark (2001) and Wright, Gardner, Moynihan and Allen (2005), who argue that the use of high involvement practices can increase productivity, but they can also lead to higher labor costs, since more staff members are required. Boselie, Dietz and Boon (2005) indicates the possibility that organizations with high performance at a particular time might invest their additional resources in implementing human resource programs that later lead to improved performance, opening the door to the existence of a possible inverse causal relationship, which could only be ruled out by longitudinal or quasi-longitudinal studies.

In spite of the existence of sporadic contradictory results, most researchers have confirmed, through numerous field studies, a positive relationship between the use of HIWP and improved results, whether they be operational, financial or in terms of human resources (Conci, 2012).

However, on the methodological level, we find some aspects that raise doubts about the results obtained in these field studies that propose to identify the relationships that occur in this "black box". First we should mention the fact that the questionnaires used by the researchers to analyze these relationships between HIWP and business performance are quite varied, as specific questionnaires are usually created for each study, and on rare occasions those designed by other researchers are reused, which means that we do not have a measurement model that is consistent and widely disseminated throughout the scientific community (Marin-Garcia, 2013).

In addition, and more importantly, it is not common to find the validation of the measurement models used, as almost all the works are focused on proving the structural models, and it is even rarer to find studies that validate the measurement models in different samples (Marin-Garcia \& Conci, 2010, 2012).

And finally, in the few studies that have considered the validation of the measurement model, the truth is that the results are not very conclusive in terms of HIWP (Marin-Garcia \& Conci, 2009, 2012, 2013).

These inconsistencies on a methodological level, which have yet to be solved, have contributed to the fact that HIWP are not yet an established theoretical body, but rather an area of theoretical effervescence (Boxall, 2012). 
In this framework and keeping in mind that the attempts to validate the model used to measure HIWP using reflective models between items and constructs (Marin-Garcia \& Conci, 2013) have not had good results, in this work we propose to:

- Verify the HIWP measurement model in Lawler's questionnaire (1986) as a formative model (composite mode B).

- Analyze the predictive capacity of the proposed model.

For our research, we used as a reference the questionnaire designed by Lawler (1986), since it is one of the few models that have been reused by other researchers to evaluate the use of HIWP. The questionnaire proposed by Lawler results in a model of constructs in which the relationships are unspecified, and therefore they could be considered as either reflective or formative, but in spite of this possible double nature, and even though few studies have explicitly established this relationship, all the studies consulted have opted to consider reflective models, judging by the type of statistical analysis that they apply (Marin-Garcia \& Conci, 2013).

Figure 1 shows the model to be verified, which is adapted from Lawler's questionnaire (1986) and takes into account the results of previous studies (Marin-Garcia \& Conci, 2013). The variables (constructs), indicators and relationships that it considers are:

- "Communication", "training", "rewards" and "empowerment". These are first order and emergent exogenous constructs, in other words, they are made up of formative indicators, which as described below, implies that the constructs are the function of the indicators that precede the construct.

- "HIWP". This is a second order formative construct that completes the HIWP measurement model.

- "Perceived results". This is a first order reflective endogenous construct, based on the results of previous studies (Conci, 2012). 


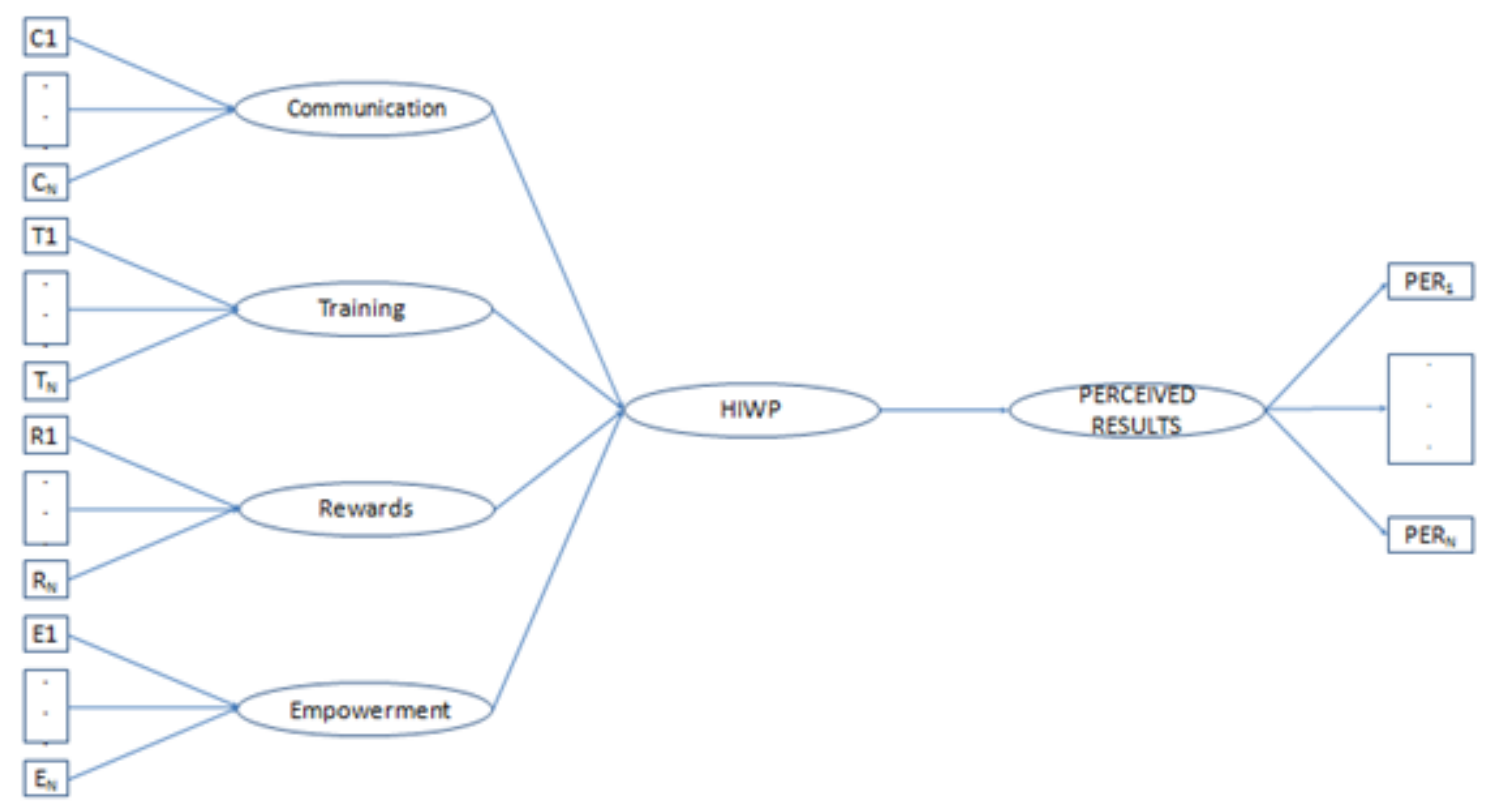

Figure 1. The initial model to be verified. Based on Lawler III (1986); Marin-Garcia \&Conci (2013)

Therefore, using as a starting point the existing theoretical body of literature, which reports a positive relationship between HIWP and performance (Arthur, 1994; Camps \& Luna-Arocas, 2009; Ericksen, 2007; Guerrero \& Barraud-Didier, 2004; Guthrie, Spell \& Nyamori, 2002; Huselid, 1995; Wright et al., 2005; Zheng, Morrison \& O'Neill, 2006), by verifying the model developed by Lawler (1986) to measure HIWP, we will also analyze whether a positive relationship exists. If on the other hand, when we associate HIWP with performance, we fail to find the positive relationship that has been established on a theoretical level, we must conclude that the measurement model we use is incorrect.

Accordingly, if we are able to validate the model, we will have a tool to measure HIWP, which raises no doubts on a methodological level, and which therefore can be used in a valid and reliable manner.

With regard to the business performance measurement, even though the proposed model has been validated in previous studies, we will also undertake its validation in this work, with the aim of completing all the stages suggested by Hair, Ringle and Sarstedt (2013) to ensure minimum quality in studies using the PLS analyzing technique.

This partial least squares structural equation modeling technique (PLS-SEM) does not allow us to establish causal relationships (it is not confirmatory), but it is the most appropriate for making predictions and it also makes it possible for us to evaluate the relationship between first order items and 
constructs, and between these and second order constructs, both reflectively and formatively. SmartPLS (Ringle, Wende \& Becker, 2015) was the software used.

In terms of data, we will use the results from field studies conducted in the United States during 1996 and 1999 (Lawler III, Mohrman \& Benson, 2001; Lawler III, Mohrman \& Ledford, 1998), and in Spain in 1997 (Marin-Garcia, Bonavía Martín \& Miralles Insa, 2008).

\subsection{Lawler's model. The "black box" between HIWP and performance}

Lawler et al. (Lawler III, 1986), members of the CEO (Center for Effective Organizations) at the University of Southern California, designed a questionnaire to analyze the use of certain practices considered to behigh involvement/performance and their repercussion on certain result indicators.

This questionnaire has been sent to companies on the U.S. Fortune 1000 list by the Center for Effective Organizations since 1987, in a total of 6 surveys conducted prior to 2002, with a frequency of once every three years. While these surveys cannot be properly considered a longitudinal study, given that the Fortune list members change over the years, they do indicate a large increase in the number of companies using HIWP, as well as the percentage of employees affected. For example, the number of companies in which at least $20 \%$ of employees use self-managed teams increased from $8 \%$ in 1987 to $32 \%$ in 1996, and even though the results of the last survey conducted in 2002 show that the adoption of employee participation programs suffered a slight deceleration (Lawler III et al., 2001), the percentage of large companies using HIWP, and the number of employees affected, grew considerably throughout the assessed series.

The importance of Lawler's questionnaire (1986) lies in the fact that its use has extended beyond the research conducted by Lawler from the CEO, and with some adaptations, it has been used by other researchers in this field (Benson et al., 2006; Coye \& Belohlav, 1995; Drehmer, Belohlav \& Coye, 2000; Guerrero \& Barraud-Didier, 2004; Lawler, 2005; Marin-Garcia et al., 2008; Yu, Finegold, Lawler \& Cochran, 2000), so that if we are successful in validating the measurement model Lawler proposes, we will contribute to strengthening and confirming the results obtained by other researchers who have used it in the past.

In their model, Lawler et al. propose the existence of 4 constructs in terms of HIWP: "communication", "training", "rewards" and "empowerment". Each of these constructs is measured through a series of indicators (see Appendix 1). 


\begin{tabular}{|l|l|}
\hline CONSTRUCT & DEFINITION \\
\hline Communication & $\begin{array}{l}\text { Type of information that is shared with the employees for decision-making related to the } \\
\text { improvement of their job position or the improvement of the company }\end{array}$ \\
\hline Training & $\begin{array}{l}\text { Systematic and formal training offered to employees during the last three years and in different skills } \\
\text { to increase their commitment and for the development of global quality management or other } \\
\text { similar systems }\end{array}$ \\
\hline Rewards & The use of reward programs or systems that tend to encourage employee involvement \\
\hline Empowerment & $\begin{array}{l}\text { Organizational changes or programs that allow decision-making or power to be transferred to } \\
\text { employees }\end{array}$ \\
\hline
\end{tabular}

Table 1. HIWP constructs. Source: Lawler III et al.(1998); Lawler III et al. (2001)

For each indicator, those surveyed were asked to indicate the degree to which each of the high involvement practices are used in their company, on a scale of 1 to 7 , corresponding to the following ranges: 1 ( $0 \%$ of employees participate in these activities or programs), 2 (1\%-20\%), 3 (21\%-40\%), 4 (41\%-60\%), 5 (61\%-80\%), 6 (81\%-99\%), 7 (100\% of employees).

On the other hand, the business performance construct is measured via subjective indicators, using the question "How would you rate the positive or negative impact, if any, of the efforts to achieve employee involvement in the following company performance indicators?". To answer this question, Lawler proposes several items related to the constructs "performance and service", "human resources results" and "organization results", with the following response scale: very negative (1), negative (2), neutral (3), positive (4) and very positive (5).

In terms of the relationship between the items and the constructs of the model, neither Lawler nor his collaborators from the $\mathrm{CEO}$, or in general, any of the researchers who have used his questionnaire explain these relationships. Therefore, it is not clear whether they are considered as reflective or formative. However, from the systematic procedure and the statistics used in the data analysis, it is inferred that the relationship between the items/indicators and the constructs, as well as the relationship between the constructs and the second order factor, when proposed, is treated as reflective.

Given that the validation of the measurement model is a preliminary step to test any structural model (Hair, Ringle et al., 2013), other researchers have already asked the question that we are considering in this work; however, these previous works have detected problems, both in the validation of the measurement model of the exogenous constructs (communication, training, rewards and empowerment), and in the exogenous HIWP constructs and performance, and they thus propose variations to the initial model presented by Lawler, as described below. 
With regard to the previous results of the validation of the exogenous constructs, in general, in studies in which Cronbach's alpha data are provided, it has been found that those of the constructs of communication and training are good, but those of empowerment and rewards fall below 0.70 in the few cases in which their value has been reported (Marin-Garcia \& Conci, 2013).

In other studies in which all the practices of high involvement were considered together as a single construct, the Cronbach's alphas have values near the threshold (0.7), both slightly above and slightly below: 0.78 (Datta, Guthrie \& Wright, 2005), 0.69 (Guthrie, 2001), 0.67 (Huselid, 1995).

More consistent in terms of the HIWP measurement model validation is the work of Yu et al. (2000), who also used Lawler's questionnaire and analyzed the relationships among items and constructs in a reflective manner. In this work, conducted with Asian companies, the results obtained confirm that the measurement model does not fit the data collected from companies in the United States, concluding that in the Asian environment, it is difficult to consider the constructs of empowerment and rewards to be unidimensional, and much less consider a latent second order factor representing HIWP. However, both communication and training do fit well as unidimensional constructs (the factor loadings of the items of each dimension are significant and almost all are above 0.60 ).

Continuing with the analysis of the works that consider the validation of the HIWP measurement model, in the work by Marin-Garcia (2013) a confirmatory analysis was conducted using CovarianceBased Structural Equation Modeling (CB-SEM) to evaluate the four constructs proposed by Lawler (communication, training, rewards and empowerment) and determine whether the grouping of items in these four constructs fits the three independent field data series (from different countries and different years), which are the same ones that we will use in our research. For this analysis, the EQS program was used with data from Spain (1997) and the United States (1996 and 1999), and the proposed goal was to evaluate whether the grouping of items into the categories considered in the theoretical models fits the data set obtained, according to a reflective model.

In this analysis, only the constructs "training" and "communication" clearly passed the convergent validity test, however, it was only possible to partially validate the reflective measurement model for the scales of empowerment and rewards.

On the other hand, with regard to the result of previous studies on the validation of the measurement model for the construct "performance", the work by Conci (2012) proposed to validate the measurement model for the scale of results, based on the data obtained from Spanish companies (Marin-Garcia et al., 2008), using an adaptation of the model by Lawler et al. (1991). 
The EQS technique was used in the analysis process, based on a reflective relationship between the indicators and the performance constructs.

During the first attempt to validate the model proposed by Lawler, with 3 different performance constructs (performance and service, human resources results and organization results) the statistics calculated do not show a good fit, so a model was also analyzed that represented all the items in a single construct; in this case, the goodness of fit statistics also failed to exceed the recommended limits. Finally, and after making several intermediate adjustments, the confirmatory factor analyses of the data from 98 Spanish companies allowed Conci (2012) to validate a model that had very good convergent validity statistics, but eliminating those items whose standardized factor loading was low; it was thus proposed that the items forming part of the construct "performance" be those shown in Table 2.

\begin{tabular}{|l|l}
\hline Perceived Results & Productivity, quality, customer service, employee satisfaction, competitiveness
\end{tabular}

Table 2. Indicators forming part of the construct "perceived results". Source: Conci (2012)

\subsection{About the formative models}

In our analysis, we draw from the premise that the constructs in themselves are neither formative nor reflective, rather that the key is in how they have been conceived, their relationships and how they are measured (Hair, Hult, Ringle \& Sarstedt, 2013).

Bearing this in mind, and given that the previous studies available that have attempted to validate the model with reflective relationships have not produced good results, as indicated in the previous section, we have analyzed the extent to which the model can be analyzed as formative.

To do this, we have applied the approach proposed by Jarvis, Mackenzie and Podsakoff (2003) to identify a formative model: "Assuming that all the measures of a construct are encoded in the same direction, does the increase in one of the indicators in a particular direction imply that the rest must change in a similar manner? If the answer is yes, we have reflective indicators. If the answer is no, we have formative indicators". Analyzing how the four constructs have been operationalized that make up our HIWP measurement model, the answer to this question is no, so in theory, this indicates that we have a formative model. 
To confirm that we really have a formative model, compliance with the 5 theoretical conditions proposed by Hair, Hult et al. (2013) was verified:

- causal priority of the indicators towards the construct (the formative construct is the result of the combination of its indicators);

- the construct is a combination of the indicators;

- the indicators represent the causes of the construct;

- variations in the indicators cause changes in the construct, but not the other way around; and

- their indicators are not interchangeable.

With regard to the conceptual domain of each of the constructs and the number of indicators evaluated to infer them, they are the same as those established in the questionnaire proposed by Lawler (1986), and thus they have not be subject to analysis.

\section{Methodology}

Bearing in mind that the basis of our rationale is to prove the existence of formative relationships between the indicators (items) and the HIWP constructs, we will use a partial least squares structural equation modeling technique (PLS-SEM) that has been widely used in the social sciences in recent years (Hair, Hult et al., 2013).

The data from the USA come from the FORTUNE 1000 Company list, where the country's largest companies are represented, including both industrial and service companies, and the data will be used from the surveys conducted in 1996 and 1999. The data from Spain were collected in 1997 and come from a random sample of 861 industrial companies found on the Fomento de la Producción list of the 2500 largest companies (1259 were industrial establishments).

In the specific case of the data from the USA, those corresponding to the years 1996 and 1999 have been chosen so that the final data set, including Spain-1997, would be from almost the same period of time.

In the 1999 survey in the USA, 137 responses were received, corresponding to a 15\% response rate. Approximately half of the responses were from production companies and the rest were from service 
companies. $44 \%$ of the responses came from the Human Resources Director and the remaining $66 \%$ were from other high-level directors. In the 1996 survey in the USA, 201 responses were received, corresponding to a $22 \%$ response rate. Approximately half of the responses were from production companies and the rest were from service companies. $45 \%$ of the responses came from Human Resources Directors and the remaining 65\% were from other high-level directors. The data from Spain were collected in 1997, and 101 responses were received, which corresponds to a response rate of 12\%. All were from industrial companies. $63 \%$ of the responses came from the Human Resources director and the remaining $37 \%$ were from other high-level directors.

Even though the original questionnaire from Lawler is broader in scope, in our analysis, we have only considered the data from those indicators that are present in all 3 data series that we used as our starting data, which gives us a total of 30 indicators related to the constructs of high involvement practices (See Appendix 1). The 30 items serve to measure the four constructs proposed in this study: communication (5 items), training (7 items), rewards ( 9 items) and empowerment ( 9 items), which were originally measured using a scale of 1 to 7 with the following equivalences: $1(0 \%$ of employees participate in these activities or programs), 2 (1\%-20\%), 3 (21\%-40\%), 4 (41\%-60\%), 5 (61\%-80\%), 6 (81\%-99\%), 7 (100\% of employees).

On the other hand, the business performance construct is measured via subjective indicators, using the question "How would you rate the positive or negative impact, if any, of the efforts to achieve employee involvement in the following company performance indicators?". Even though Lawler originally proposed 11 items, 4 of which were related to "performance and service", 4 were related to "human resources results" and 3 were related to "organization results," and a scale of 1 to 5 was used on each item, with the following equivalences: 1 (very negative), 2 (negative), 3 (neutral), 4 (positive) and 5 (very positive), in our model, which is based on the validation conducted by Conci (2012), only the 10 indicators are used that were included in the Spanish questionnaire (see Appendix 1).

In order to evaluate the data using PLS, we have converted the HIWP scales, which are in an interval format ( 1 to 7 ), to the midpoint value of the interval of the $\%$ of employees who participate in these activities or programs (see Table 3). 


\begin{tabular}{|c|c|r|}
\hline $\begin{array}{c}\text { Original data (interval } \\
\text { scale) }\end{array}$ & $\begin{array}{c}\% \text { of employees who participate in these activities or } \\
\text { programs }\end{array}$ & $\begin{array}{c}\text { Converted data } \\
\text { (mean value of each } \\
\text { interval) }\end{array}$ \\
\hline 1 & $0 \%$ of employees participate in these activities or programs & 0 \\
\hline 2 & $1 \%-20 \%$ & 10 \\
\hline 3 & $21 \%-40 \%$ & 30 \\
\hline 4 & $41 \%-60 \%$ & 50 \\
\hline 5 & $61 \%-80 \%$ & 70 \\
\hline 6 & $81 \%-99 \%$ & 90 \\
\hline 7 & $100 \%$ of employees & 100 \\
\hline
\end{tabular}

Table 3. Transformation of the values for the HIWP items

The performance construct is not rescaled because it does not represent an interval.

In terms of the verification methodology, the protocol suggested by Hair, Hult et al. (2013) was applied for both the validation of the measurement model and for the structural model:

- To verify the HIWP measurement model, the 3 proposed stages will be considered: evaluation of the convergent validity, using a redundant analysis; analysis of the multicollinearity of the indicators and finally, evaluation of the significance and relevance of the formative indicators. The verification will be carried out independently for each of the 3 samples (Spain-1997, USA1996 and USA-1999), except for in the first stage (evaluation of the convergent validity), since data are only available to evaluate the sample USA-1996.

- The validity of the reflective measurement model of the construct "performance" is also verified, taking into account the results of previous research that validated the measurement model as reflective in the case of the sample Spain-1997 (Conci, 2012).

- Once the measurement model has been verified, we will analyze the structural model, following the 5 stages indicated by Hair, Hult et al. (2013): evaluating collinearity; evaluating the significance and relevance of the relationships in the structural model (path coefficients); evaluating the determination coefficient $\left(\mathrm{R}^{2}\right)$; evaluating the effect size $\left(\mathrm{f}^{2}\right)$; and finally, evaluating the predictive relevance $\mathrm{Q}^{2}$ and the $\mathrm{q}^{2}$ effect sizes. Once again, we will perform this verification independently for each of the three samples being analyzed.

The definition of the second order construct "HIWP" originates from the theory that defines the HIWP as a set of programs that act synergistically and improve organizational efficiency by creating working conditions that increase employee satisfaction, motivating them to get involved in the organization and to better perform their tasks (Huselid, 1995). Furthermore, taking into account the 
indications by Barroso Castro, Cepeda Carrión and Roldán Salgueiro (2007), this construct has been defined with formative relationships, given that it is an additive combination of the 4 dimensions (communication, training, rewards and empowerment), which represent heterogeneous facets that make a single contribution to the construct. With regard to the operationalization of this construct, between the two techniques that are generally used to estimate the parameters of second order constructs in PLS,

- the repetition of indicators and

- the two-stage method (Ringle et al., 2015), in our study, we have opted to use the repetition of indicators method, with formative relationships, given that it enables us to estimate all the relationships among the constructs simultaneously (Hair, Hult et al., 2013).

Below is a brief description of the methodology proposed by Hair, Hult et al. (2013) for the verification of the measurement model and of the structural model.

\subsection{Formative models. Verification of the measurement model}

\subsubsection{Stage 1 - Evaluation of the convergent validity}

The convergent validity represents the extent to which an indicator is related to other indicators in the same construct. When the formative measurement models are verified, we must evaluate the extent to which the formative construct is correlated with a reflective measurement of the same construct. This process is also known as redundant analysis, since we are assessing whether the indicators are included in the formative as well as the reflective construct. The path-coefficient value that connects the two constructs is indicative of the validity of the set of formative indicators in order to evaluate the construct of interest. The proposed objective is to obtain an $r^{2}$ value of 0.81 or at least 0.64 . If the model demonstrates a lack of convergent validity, this implies that the indicators that form part of the formative model do not contribute as sufficiently as expected, and thus the constructs must be conceptually reformulated by replacing and/or adding indicators.

In our case, in order to check the convergent validity, a question has been used that was asked on the USA-1996 questionnaire, and which represents the overall level of use of HIWP: 
"Approximately what percent of your corporation's employees are in units in which each of the following patterns of employee involvement practice is predominant? Please, allocate $100 \%$ in answering 1-5.

- None. No significant employee involvement exits in these parts of the corporation,

- Improvement Teams. Employee involvement focuses on special groups that are responsible for recommending improvements to management. These groups may be participation groups, quality circles...

- Job involvement. Employee involvement focuses on creating work designs that are highly motivating, such as self-managing teams. Training focuses on job specific skills and/or team functioning...

- Business involvement. Employees are involved heavily in the management of the business. Improvement teams and job involvement approaches may be used as part of this strategy...

- Other form of involvement. Employee involvement approaches not described by 2,3 or 4." (Lawler III, 1986)

As can be seen, this question was formulated as a scale variable, but it has been converted into a single item variable by calculating the weighted mean, after assigning the weights indicated in Table 4 to each of the options offered on the questionnaire.

\begin{tabular}{|l|r|}
\hline \multicolumn{1}{|c|}{ Question } & \multicolumn{1}{|c|}{$\begin{array}{c}\text { Weight } \\
\text { assigned }\end{array}$} \\
\hline $\begin{array}{l}\text { 1. None. No significant employee involvement exists in these parts of the corporation } \\
\text { r. Improvement Teams. Employee involvement focuses on special groups that are responsible for } \\
\text { recommending improvements to management. These groups may be participation groups, quality } \\
\text { circles... }\end{array}$ & 5 \\
\hline $\begin{array}{l}\text { 3. Job involvement. Employee involvement focuses on creating work designs that are highly } \\
\text { motivating, such as self-managing teams. Training focuses on job specific skills and/or team } \\
\text { functioning... }\end{array}$ & 7 \\
\hline $\begin{array}{l}\text { 4. Business involvement. Employees are involved heavily in the management of the business. } \\
\text { Improvement teams and job involvement approaches may be used as part of this strategy... }\end{array}$ & 10 \\
\hline 5. Other form of involvement. Employee involvement approaches not described by 2,3 or 4. & 3 \\
\hline
\end{tabular}

Table 4. Transformation of the questions concerning the overall use of HIWP into a reflective single item variable. 


\subsubsection{Stage 2 - Evaluation of the multicollinearity}

In a formative model in which the indicators are not interchangeable, no close correlations should exist between the items that make up each construct (Cepeda \& Roldán, 2004). As a matter of fact, close correlations between indicators would pose methodological problems and difficulties in interpreting the results, since they would complicate the identification of the effect that each has on the concept (Hair, Hult et al., 2013).

To evaluate multicollinearity, the variance inflation factor (VIF) is calculated to determine whether it is greater than 0.2 and less than 5 for each of the indicators that make up the different constructs. Version 3.2.3 of SmartPLS provides this value directly.

\subsubsection{Stage 3 - Evaluation of the significance and relevance of the formative indicators}

Another important criterion for assessing the contribution made by a formative indicator and its relevance is its outer weight. Outer weight is the result of a multiple regression (Hair, Hult et al., 2013) in which the constructs are the dependent variable and the indicators (items) are the independent variables. Given that the construct itself is formed by its underlying formative indicators (items), a multiple regression analysis should provide an $\mathrm{R}^{2}$ value of 1.0 (without any error variance, $100 \%$ of the construct is explained by the indicators). We must check whether the outer weights in the formative models are significantly different from zero, using the bootstrapping procedure (a non-parametric resampling technique).

Bearing in mind that the maximum outer weight of the indicators that make up each construct is $1 / \operatorname{root}(\mathrm{n})$, Table 5 indicates the maximum values for each construct.

\begin{tabular}{|r|r|r|r|}
\hline Communication (5) & Training (7) & Rewards (9) & Empowerment (9) \\
\hline 0.4472 & 0.3780 & 0.3333 & 0.3333 \\
\hline
\end{tabular}

Table 5. Maximum outer weight of each formative construct

To obtain the level of significance, the statistical value $\mathrm{T}$ was calculated after resampling (bootstrapping). This $\mathrm{T}$ value must be $>1.96$ (two-tailed test), if $\mathrm{p}<0.05$ and $>1.645$ for $\mathrm{p}<0.1$. 
For the resampling (bootstrapping), the following configuration has been applied:

- The missing values are replaced by the mean

- No change in sign

- Samples $=5,000$

- Level of significance $=0.05$

When the outer weight of an indicator is significant, there is empirical support to keep the indicator. When the outer weight of an indicator is not significant, but its load is relatively high $(>0.5)$, the indicator must be kept.

If neither the outer weight nor the load are significant, there is no empirical support for retaining the indicator and it should be removed from the model.

After this brief description of the methodology used to verify the formative measurement models, we will proceed to describe the methodology to verify the reflective measurement models.

\subsection{Reflective models. Verification of the measurement model}

\subsubsection{Stage 1 - Internal consistency}

The internal consistency of the indicators that make up each construct is evaluated, in other words, the rigorousness with which the indicators (items) are measuring the same construct (latent variable) is examined. In SmartPLS, the outer loading of the indicators is evaluated to determine whether it is greater than 0.708 .

\subsubsection{Stage 2 - Reliability of the indicator}

In this stage, we attempt to examine the loadings or simple correlations of each measurement or indicator with its respective construct. In this case, it is determined whether the composite reliability after a bootstrapping process has a loading of at least 0.707 in order to accept that an indicator belongs to a construct, because this would mean that the shared variance between the construct and its indicators is greater than the error variance. 


\subsubsection{Stage 3 - Convergent validity}

The aim is to evaluate whether a set of indicators really measures the construct. To analyze this type of validity, an average variance extracted (AVE) method is used. The acceptance criterion consists of verifying that the average variance extracted (AVE) of a construct is greater than 0.5 , meaning that the construct shares more than half of its variance with its indicators.

\subsubsection{Stage 4 - Discriminant validity}

With this criterion, it is verified that a particular construct is different from the others. For this verification, the variance shared by a construct with its indicators must be greater than that which it might share with other constructs included in the model.

\subsubsection{Stage 5 - Verification of the structural model}

Once the measurement model has been verified independently for each sample (USA-1996, USA-1999 and Spain-1997), an analysis of the structural model will be conducted to determine the predictive capacity of the model and the relationships among the constructs, also analyzing each of the samples separately, evaluating the amount of variance of the endogenous construct (performance) that is explained by the constructs that predict it, and the extent to which the predicting constructs contribute to the explained variance of the endogenous construct. To do this, we will evaluate two basic indexes: $\mathrm{R}^{2}$ and the path coefficients or standardized regression weights.

The process for analyzing the structural model, which follows the indications by Hair, Hult et al. (2013), has 5 stages: evaluation of collinearity; evaluation of the significance and relevance of the relationships in the structural model (path coefficients); evaluation of the coefficient of determination $\left(\mathrm{R}^{2}\right)$; evaluation of the impact (effect sizes) $\left(\mathrm{f}^{2}\right)$; and finally, evaluation of the predictive relevance $\left(\mathrm{Q}^{2}\right)$ and effect sizes $\left(\mathrm{q}^{2}\right)$ of the reflective endogenous constructs. 


\subsection{Evaluation of the structural model}

\subsubsection{Step 1 - Analysis of collinearity}

In order to ensure that there is no collinearity among the 4 constructs that make up the second order HIWP construct, a multiple regression analysis is conducted on the path coefficients of the aforementioned constructs: communication, training, rewards and empowerment. The version 3.2.3. of SmartPLS that we have used in our work provides the VIF data directly, which must be $<5$.

\subsubsection{Step 2 - Path coefficients of the structural model}

Before examining the path coefficients, which represent the relationships that exist among the constructs, it is necessary to determine whether they are significant.

To do this, the resampling or bootstrapping option is run, with the following parameters:

- The missing values are replaced by the mean

- No change in sign

- Samples $=5,000$

- $\quad$ Level of significance $=0.05$

Within each of the constructs, the value of the T statistics is also analyzed, which must be $>1.96$ (twotailed test) for $\mathrm{p}<0.05$, and $>0.98$ (one-tailed test) for $\mathrm{p}<0.05$.

After evaluating the significance, we evaluate the path coefficients, which must be interpreted in a relative manner among them. If a path coefficient is greater than another, its effect on the construct is greater, and it represents the estimated change that is produced in the endogenous construct by a unit of change in the predictive construct. In other words, it gives us information about the relative importance of each predictive construct. 


\subsubsection{Step 3 - Coefficient of determination $\left(\mathbf{R}^{2}\right.$ value)}

The $\mathrm{R}^{2}$ value, the coefficient of determination, is the value most commonly used to evaluate structural models, as it represents the predictive value that the preceding constructs have of each construct. The coefficient represents the combined effects of the combined exogenous constructs on the endogenous construct, and also represents the variance of the endogenous construct explained by the different exogenous constructs.

The $\mathrm{R}^{2}$ value ranges from 0 to 1 , and values close to 1 indicate a greater predictive capacity, although in the field of management, $\mathrm{R}^{2}$ values greater than $10 \%$ can be considered as values to be considered in spite of their low value.

\subsubsection{Step 4 - Impact measurement $\left(\mathbf{f}^{2}\right)$}

The $\mathrm{f}^{2}$ (effect size) value is a measurement of the impact of a predictive construct on the endogenous construct, and it provides valuable information about the change that occurs in the $\mathrm{R}^{2}$ value when a construct is eliminated. Thus, $\mathrm{f}^{2}$ values below 0.02 tell us that this construct barely has any effect, while values between 0.02 and 0.15 mean that the effect can be considered as medium, and values above 0.35 indicate that the construct clearly must form part of the model.

To obtain the $\mathrm{f}^{2}$ value when several constructs contribute to an endogenous construct in a structural model, the model must be recalculated, removing the constructs that contribute to it one by one, and the following formula must be applied:

$$
f^{2}=\frac{\mathrm{R}_{\text {included }}^{2}-\mathrm{R}_{\text {excluded }}^{2}}{1-\mathrm{R}_{\text {included }}^{2}}
$$

Since our structural model only has one construct (HIWP) that predicts our dependent variable (the performance construct), the $\mathrm{f}^{2}$ value cannot be calculated. 


\subsubsection{Step 5 - Blindfolding and $\mathrm{Q}^{2}$ predictive relevance}

For reflective constructs that have an effect on the predictive model, it is necessary to evaluate the $\mathrm{Q}^{2}$ predictive relevance to analyze the extent to which the exogenous constructs contribute to the explained variance of the endogenous constructs in the model. To do this, following the indications of Hair, Hult et al. (2013), the cross-validated redundancy approach is applied, running the blindfolding for the corresponding construct.

Since in our model the only reflective construct is precisely the endogenous construct that we wish to analyze, it is not necessary to perform this last step in the evaluation of the structural model.

\section{Results and discussion}

\subsection{Evaluation of the sample size}

Before proceeding with the analysis, it was assessed whether the sample size was sufficient to estimate the proposed model using the PLS-SEM technique, since the stability of the estimates can be affected by sample size (Hair, Hult et al., 2013).

Furthermore, to ensure the appropriateness of the sample size, the number of regressors that have been included in the model must be considered. Given the characteristics of the PLS estimation, it is recommended as a practical rule to determine the required sample size in order to be able to apply this technique (Cepeda \& Roldán, 2004; Hair, Hult et al., 2013), multiplying by 10 the number of indicators that form part of the formative construct with the greatest complexity (in our case, 9), and the largest number of preceding constructs that lead to an endogenous construct (in our model, 4), considering the largest result.

From this calculation, it was determined that for our model, the sample size must be greater than 90 . Bearing in mind that the analyses are going to be performed independently for each data sample (USA1996, USA-1999 and Spain-1997), this did not pose a problem, since in the case of USA-1996 we have 201 data items, for USA-1999 we have 137 cases, and for Spain-1997 we have a total of 101 cases. 


\subsection{Descriptive analysis of the constructs}

Below are the tables with the descriptive statistics for the four categories of programs (constructs) that make up Lawler's model (1986): communication, training, rewards and empowerment in the three samples that we evaluate in our study: Spain (1997), USA (1996) and USA (1999).

\begin{tabular}{|l|c|r|r|r|r|r|r|r|r|}
\cline { 2 - 10 } \multicolumn{1}{c|}{} & \multicolumn{4}{c|}{1996} & \multicolumn{3}{c|}{1999} & \multicolumn{3}{c|}{1997} \\
\cline { 2 - 10 } \multicolumn{1}{c|}{} & $\mathbf{N}$ & Mean & Stand. Dev. & N & Mean & Stand. Dev. & N & Mean & Stand. Dev. \\
\hline INFvar009 & 203 & 85.27 & 22.32 & 138 & 77.90 & 28.53 & 104 & 57.31 & 36.13 \\
\hline INFvar010 & 201 & 72.44 & 26.90 & 138 & 73.77 & 27.21 & 102 & 60.49 & 33.34 \\
\hline INFvar012 & 203 & 47.64 & 27.87 & 137 & 44.23 & 27.30 & 104 & 56.35 & 33.93 \\
\hline INFvar013 & 202 & 64.70 & 27.61 & 137 & 68.03 & 26.45 & 104 & 54.71 & 34.05 \\
\hline INFvar014 & 203 & 41.72 & 28.41 & 137 & 42.77 & 28.41 & 101 & 40.10 & 30.45 \\
\hline
\end{tabular}

Table 6. Communication indicators

The practices corresponding to the construct "communication" (Table 6) are those that present the highest degree of implementation as compared to the other categories. In the three samples, they are the ones that present the highest mean and lowest standard deviation, although the variability in the Spanish sample is greater than for the American companies. The communication flows are slightly lower in Spain, except in relation to new technologies (INFvar012), where the opposite trend is observed.

\begin{tabular}{|l|c|c|r|c|r|r|r|r|r|}
\cline { 2 - 10 } \multicolumn{1}{c|}{} & \multicolumn{4}{c|}{1996} & \multicolumn{3}{c|}{1999} & \multicolumn{3}{c|}{1997} \\
\cline { 2 - 11 } \multicolumn{1}{c|}{} & N & Mean & Stand. Dev. & N & Mean & Stand. Dev. & N & Mean & Stand. Dev. \\
\hline TRAvar015 & 202 & 36.58 & 24.61 & 135 & 31.11 & 22.22 & 104 & 34.13 & 27.58 \\
\hline TRAvar016 & 202 & 32.23 & 20.65 & 136 & 34.85 & 21.05 & 103 & 25.53 & 19.54 \\
\hline TRAvar017 & 201 & 28.66 & 20.73 & 136 & 30.88 & 23.21 & 104 & 21.35 & 17.63 \\
\hline TRAvar018 & 200 & 32.30 & 26.91 & 133 & 24.59 & 22.11 & 103 & 33.40 & 27.39 \\
\hline TRAvar019 & 201 & 40.80 & 24.58 & 136 & 38.82 & 24.68 & 103 & 38.16 & 30.96 \\
\hline TRAib6 & 202 & 58.66 & 25.66 & 136 & 59.04 & 26.88 & 104 & 56.25 & 34.05 \\
\hline TRAvar025 & 200 & 33.80 & 23.84 & 136 & 34.19 & 23.71 & 103 & 37.77 & 28.87 \\
\hline
\end{tabular}

Table 7. Training indicators

The training practices (Table 7) show a degree of use that is fairly similar in all three samples. The most common is the training necessary for the job itself (TRAib6), which reached more than half of the operators in all three samples. The rest of the programs have a moderate level of deployment and affect around $30 \%-40 \%$ of the employees. 


\begin{tabular}{|l|c|r|r|r|r|r|r|r|r|}
\cline { 2 - 10 } \multicolumn{1}{c|}{} & \multicolumn{4}{c|}{1996} & \multicolumn{3}{c|}{1999} & \multicolumn{3}{c|}{1997} \\
\cline { 2 - 11 } \multicolumn{1}{c|}{} & N & Mean & Stand. Dev. & N & Mean & Stand. Dev. & N & Mean & \multicolumn{1}{c|}{ Stand. Dev. } \\
\hline REWvar029 & 201 & 14.28 & 20.73 & 135 & 13.70 & 18.15 & 94 & 36.38 & 38.91 \\
\hline REWvar030 & 198 & 42.68 & 42.51 & 134 & 38.81 & 39.96 & 89 & 18.09 & 33.64 \\
\hline REWvar032 & 198 & 14.14 & 26.14 & 136 & 17.13 & 27.35 & 89 & 16.97 & 31.57 \\
\hline REWvar033 & 198 & 35.10 & 31.73 & 137 & 38.39 & 30.59 & 93 & 30.22 & 33.69 \\
\hline REWid6 & 200 & 26.15 & 28.61 & 136 & 30.66 & 32.62 & 88 & 26.59 & 35.00 \\
\hline REWid7 & 198 & 58.69 & 34.95 & 136 & 65.59 & 35.54 & 90 & 23.67 & 36.12 \\
\hline REWvar034 & 200 & 51.80 & 45.02 & 136 & 53.09 & 44.01 & 88 & 6.36 & 20.41 \\
\hline REWvar035 & 201 & 53.48 & 44.28 & 136 & 58.31 & 43.76 & 90 & 12.67 & 25.61 \\
\hline REWvar020 & 193 & 15.70 & 30.71 & 131 & 14.35 & 29.20 & 84 & 36.79 & 45.90 \\
\hline
\end{tabular}

Table 8. Reward indicators

In terms of rewards (Table 8), in line with what has been mentioned in different works (Conci, 2012; Marin-Garcia et al., 2008), there are differences in the degrees to which the different tools are used. Used more intensively in the United States than in Spain are the practices of profit sharing (REWvar030), non-monetary rewards (REWid7), shares in the company's capital (REWvar034) and flexible pay (REWvar035). The group complements (REWid6) show a similar level, and job security (REWvar020) and competency-based pay (REWvar029) is more common in Spain than in the USA.

Finally, the practices of "empowerment" (Table 9) generally present a degree of deployment that is fairly similar in both Spain and the USA, evidencing a low level of use of mini-business units(EMPvar041) and self-managing teams (EMPvar042) programs in both countries. However, there are differences in three of the nine programs analyzed. Opinion surveys (EMPvar036) are clearly used less in Spain than they are in the USA. Furthermore, quality circles (EMPvar038) and Unionmanagement or work commitees (EMPvar040) affect a larger percentage of the staff in Spain than in the USA.

\begin{tabular}{|l|c|r|r|r|r|r|r|r|r|}
\cline { 2 - 10 } \multicolumn{1}{c|}{} & \multicolumn{4}{c|}{1996} & \multicolumn{3}{c|}{1999} & \multicolumn{3}{c|}{1997} \\
\cline { 2 - 11 } \multicolumn{1}{c|}{} & $\mathbf{N}$ & Mean & Stand. Dev. & N & Mean & Stand. Dev. & N & Mean & Stand. Dev. \\
\hline EMPvar027 & 202 & 39.75 & 35.25 & 137 & 40.88 & 35.51 & 96 & 35.63 & 41.16 \\
\hline EMPvar036 & 201 & 58.81 & 38.32 & 135 & 64.15 & 37.86 & 94 & 21.81 & 33.31 \\
\hline EMPvar037 & 201 & 28.41 & 23.84 & 135 & 23.48 & 24.41 & 91 & 27.81 & 30.32 \\
\hline EMPvar038 & 202 & 16.24 & 21.85 & 135 & 12.89 & 17.99 & 95 & 28.53 & 32.12 \\
\hline EMPvar039 & 202 & 37.38 & 28.78 & 136 & 32.87 & 27.75 & 92 & 31.85 & 32.41 \\
\hline EMPvar040 & 200 & 7.55 & 14.30 & 135 & 6.22 & 11.52 & 97 & 31.24 & 32.35 \\
\hline EMPvar041 & 200 & 14.80 & 20.62 & 132 & 14.62 & 22.76 & 83 & 7.35 & 22.74 \\
\hline EMPvar042 & 200 & 17.60 & 19.26 & 137 & 16.20 & 19.22 & 88 & 10.57 & 23.31 \\
\hline EMPp5q9 & 200 & 14.05 & 15.82 & 137 & 15.18 & 16.94 & 86 & 11.51 & 24.81 \\
\hline
\end{tabular}

Table 9. Empowerment indicators 


\subsection{Results}

\subsubsection{HIWP. Evaluation of the measurement model. Stage 1 - Convergent validity}

From the analysis of the correlation between the second order formative construct and a reflective measure of the same construct, also known as a redundant analysis, we obtained the path coefficient that relates HIWP (formative) to HIWP (reflective). For the sample USA-1996, this value is 0.65, which is slightly above the acceptance limit of 0.64 (Hair, Hult et al., 2013), as shown in Figure 2.

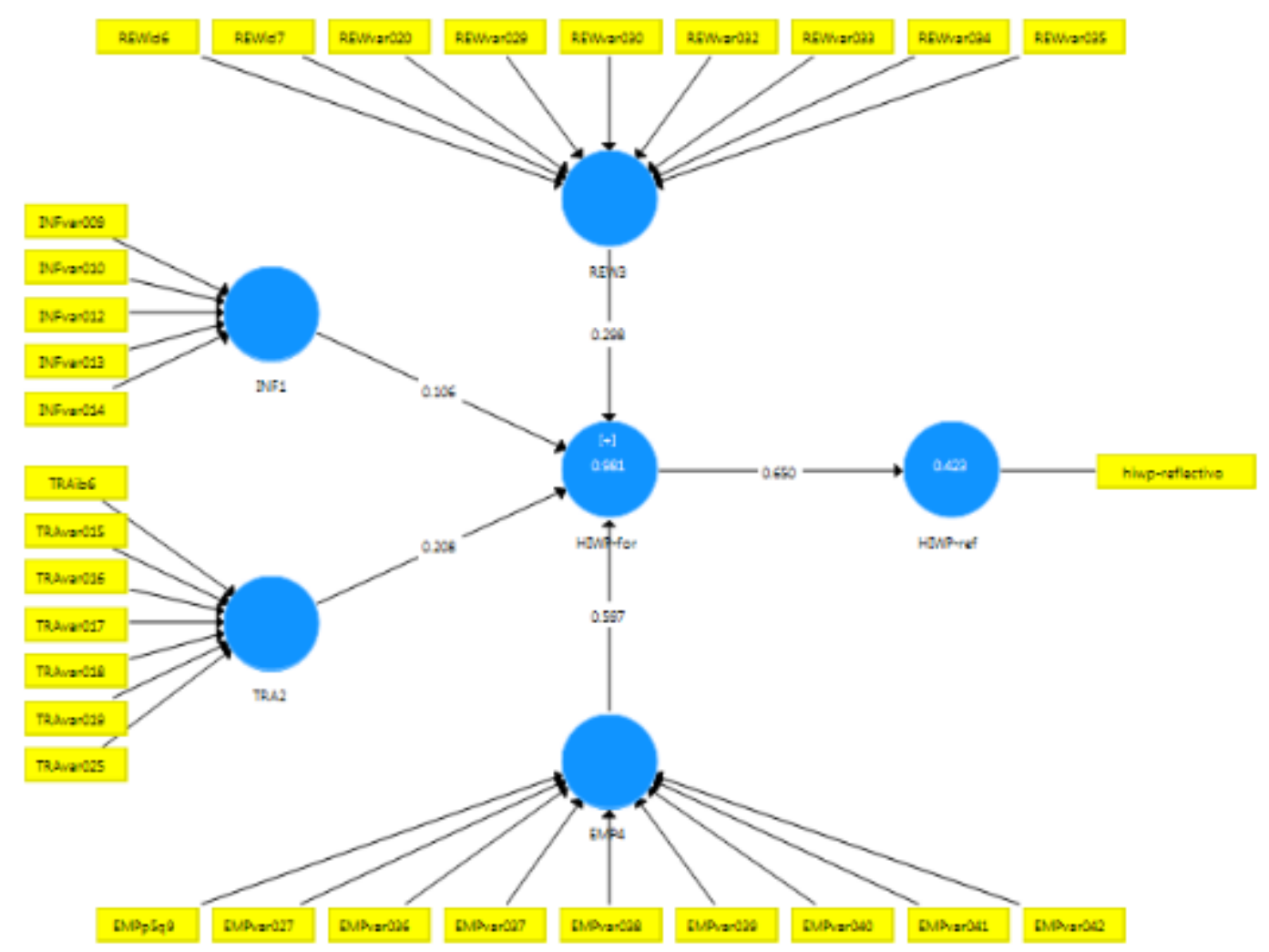

Figure 2. Model used to evaluate the convergent validity of the formative HIWP measurement model

\subsubsection{HIWP. Evaluation of the measurement model. Stage 2 - Multicollinearity}

The lack of collinearity is evaluated through the variance inflation factor (VIF) for the indicators of each formative construct in each of the samples analyzed. All the values fall between 1.053 and 3.172, which are far below the minimum thresholds (values of less than 3.3 or 5) (Hair, Hult et al., 2013), and therefore we can confirm that there is no strong correlation between the indicators or dimensions of each of the formative constructs in any of the three samples analyzed. 
Furthermore, in the multicollinearity analyses between each group of indicators, the results also show the absence of collinearity between the items that make up the second order construct in the samples USA-1996, USA-1999 and Spain-1997, so we can conclude that, with regard to the absence of collinearity, the data are acceptable.

\subsubsection{HIWP. Evaluation of the measurement model. Stage 3 - Evaluation of the significance} and relevance of the formative indicators

In this stage, the intent is to determine the extent to which a given indicator is different from the other indicators in the construct.

\begin{tabular}{|c|c|c|c|c|c|c|c|c|c|c|}
\hline & \multicolumn{2}{|c|}{ EEUU-96 } & \multicolumn{2}{|c|}{ EEUU-99 } & \multicolumn{2}{|c|}{ ESP-97 } & \multirow[b]{2}{*}{96} & \multirow[b]{2}{*}{99} & \multirow[b]{2}{*}{97} & \multirow[b]{2}{*}{ ¿Ok? } \\
\hline & $\begin{array}{l}\text { Weight } \\
\text { (T) }\end{array}$ & Loading & $\begin{array}{l}\text { Weight } \\
\text { (T) }\end{array}$ & Loading & $\begin{array}{l}\text { Weight } \\
\text { (T) }\end{array}$ & Loading & & & & \\
\hline EMPp5q9 -> 4EMP & 0.225 & 0.367 & 1.152 & 0.49 & 0.527 & 0.379 & NOK & NOK & NOK & no \\
\hline EMPvar027 -> 4EMP & 0.44 & 0.323 & 0.397 & 0.123 & 1.051 & 0.694 & NOK & NOK & OK & si \\
\hline EMPvar036 -> 4EMP & 2.889 & 0.617 & 0.91 & 0.395 & 0.801 & 0.608 & OK & NOK & OK & si \\
\hline EMPvar037 -> 4EMP & 2.238 & 0.72 & 1.206 & 0.702 & 0.968 & 0.724 & $\mathrm{OK}$ & $\mathrm{OK}$ & OK & si \\
\hline EMPvar038 -> 4EMP & 0.127 & 0.368 & 2.478 & 0.715 & 1.551 & 0.647 & NOK & OK & OK & si \\
\hline EMPvar039 -> 4EMP & 1.965 & 0.701 & 2.448 & 0.761 & 1.629 & 0.808 & OK & OK & OK & si \\
\hline EMPvar040 -> 4EMP & 0.743 & 0.367 & 1.606 & 0.433 & 0.39 & 0.432 & NOK & NOK & $\mathrm{NOK}$ & no \\
\hline EMPvar041 -> 4EMP & 1.277 & 0.455 & 0.63 & 0.504 & 0.067 & 0.306 & NOK & OK & NOK & si \\
\hline EMPvar042 -> 4EMP & 2.772 & 0.596 & 0.687 & 0.594 & 0.578 & 0.45 & OK & OK & $\mathrm{NOK}$ & si \\
\hline INFvar009 -> 1INF & 0.482 & 0.318 & 0.733 & 0.495 & 0.264 & 0.542 & NOK & NOK & OK & si \\
\hline INFvar010 -> 1INF & 2.531 & 0.781 & 2.032 & 0.763 & 2.251 & 0.891 & OK & OK & OK & si \\
\hline INFvar012 -> 1INF & 1.137 & 0.746 & 1.775 & 0.811 & 2.461 & 0.879 & OK & OK & OK & si \\
\hline INFvar013 -> 1INF & 0.771 & 0.663 & 0.409 & 0.654 & 0.158 & 0.593 & $\mathrm{OK}$ & $\mathrm{OK}$ & OK & si \\
\hline INFvar014 -> 1INF & 1.608 & 0.789 & 2.094 & 0.714 & 0.328 & 0.545 & OK & OK & OK & si \\
\hline REWid6 -> 3REW & 2.381 & 0.464 & 2.51 & 0.531 & 0.709 & 0.455 & OK & OK & NOK & si \\
\hline REWid7 -> 3REW & 1.731 & 0.505 & 1.394 & 0.378 & 1.532 & 0.71 & OK & NOK & OK & si \\
\hline REWvar020 -> 3REW & 3.045 & 0.513 & 0.279 & 0.111 & 1.312 & 0.511 & OK & NOK & OK & si \\
\hline REWvar029 -> 3REW & 4.311 & 0.64 & 4.127 & 0.646 & 0.765 & 0.2 & OK & OK & NOK & si \\
\hline REWvar030 -> 3REW & 1.525 & 0.337 & 1.959 & 0.398 & 0.281 & 0.216 & NOK & OK & $\mathrm{NOK}$ & si \\
\hline REWvar032 -> 3REW & 1.6 & 0.221 & 1.517 & 0.468 & 1.647 & 0.697 & NOK & NOK & OK & si \\
\hline REWvar033 -> 3REW & 0.298 & 0.19 & 0.046 & 0.31 & 1.08 & 0.585 & NOK & NOK & OK & si \\
\hline REWvar034 -> 3REW & 0.724 & 0.289 & 0.618 & 0.332 & 1.065 & 0.408 & NOK & NOK & NOK & no \\
\hline REWvar035 -> 3REW & 0.37 & 0.112 & 0.895 & 0.122 & 0.041 & 0.385 & NOK & NOK & NOK & no \\
\hline TRAib6 -> 2TRA & 2.25 & 0.725 & 0.577 & 0.274 & 2.026 & 0.92 & OK & NOK & OK & si \\
\hline TRAvar015 -> 2TRA & 1.393 & 0.701 & 0.07 & 0.673 & 0.315 & 0.781 & OK & OK & OK & si \\
\hline TRAvar016 -> 2TRA & 0.497 & 0.533 & 0.397 & 0.431 & 0.107 & 0.765 & $\mathrm{OK}$ & NOK & OK & si \\
\hline TRAvar017 -> 2TRA & 0.942 & 0.597 & 1.179 & 0.673 & 0.513 & 0.522 & OK & OK & OK & si \\
\hline TRAvar018 -> 2TRA & 1.781 & 0.608 & 3.042 & 0.855 & 0.152 & 0.733 & OK & OK & OK & si \\
\hline TRAvar019 -> 2TRA & 0.752 & 0.655 & 1.138 & 0.668 & 1.075 & 0.833 & $\mathrm{OK}$ & $\mathrm{OK}$ & OK & si \\
\hline TRAvar025 -> 2TRA & 2.904 & 0.791 & 1.195 & 0.637 & 0.156 & 0.567 & OK & OK & OK & si \\
\hline & & & & & & OK & 19 & 17 & 21 & 26 \\
\hline & & & & & & NOK & 11 & 13 & 9 & 4 \\
\hline
\end{tabular}

Table 10. Evaluation of significance and relevance 
As shown in Table 10, of the 30 indicators, 26 meet the significance and relevance criteria in at least one of the samples (11 of them in all samples, 9 in 2 samples and 6 in only 1 of them). The 4 indicators that do not meet significance and relevance criteria in any of the samples are:

- 2 in the construct "rewards": REWvar034 (share in the company's capital - Stock option plan) and REWvar035 (flexible pay/payment in kind).

- 2 in the construct "empowerment": EMPp5q9 (advisory committees) and EMPvar040 (Union Management, work councils or collective bargaining committees).

From the analysis of these data, it can be concluded that all the items in the communication and training constructs meet, in at least one of the samples, the significance and relevance criteria required in a formative model.

On the contrary, the constructs "rewards" and "empowerment" have several items that do not meet either the significance or relevance criteria in any of the samples, which evidences that these items are not different from the rest of the items in the construct.

These data lead us to consider modifications in the model for future research, which would be along the lines of what has been indicated by other authors (Conci, 2012), who propose creating several constructs related to rewards and empowerment:

- In "rewards", regrouping the items in "rewards to promote participation" and "performancebased compensation".

- In "empowerment", distinguishing between "sharing in decision making" and "work redesign practices".

After evaluating the HIWP formative measurement model, we proceed to evaluate the measurement model for the construct "performance" (see Figure 1), which is configured as a reflective first order construct with 10 indicators (see Appendix 1). 


\subsubsection{Performance. Verification of the measurement model. Stage 1 - Internal consistency}

To evaluate the measurement model for the construct "performance", after obtaining the outer loading value for the indicators (Hair, Hult et al., 2013), which is shown in Table 11, it was verified whether it was greater than 0.708 (values above 0.6 are acceptable).

The analysis in Table 11 shows that in the sample USA-1999, all the indicators present internal consistency, while the sample Spain-1997 is the one that demonstrates the most problems, although only the indicator "PERFe210" ("flexibility") is unacceptable. These problems in the Spanish sample are consistent with the data of previous studies (Conci, 2012).

\begin{tabular}{|l|r|r|r|l|l|l|}
\cline { 2 - 7 } \multicolumn{1}{c|}{} & EEUU96 & EEUU99 & ESP97 & EEUU96 & EEUU99 & ESP97 \\
\hline PERFe210 <- 5PERF & 0.717 & 0.741 & 0.573 & OK & OK & NOK \\
\hline PERFe211 <- 5PERF & 0.688 & 0.724 & 0.657 & ACCEPT & OK & ACCEPT \\
\hline PERFvar157 <- 5PERF & 0.813 & 0.826 & 0.732 & OK & OK & OK \\
\hline PERFvar158 <- 5PERF & 0.786 & 0.839 & 0.735 & OK & OK & OK \\
\hline PERFvar159 <- 5PERF & 0.75 & 0.788 & 0.652 & OK & OK & ACCEPT \\
\hline PERFvar160 <- 5PERF & 0.765 & 0.827 & 0.711 & OK & OK & OK \\
\hline PERFvar161 <- 5PERF & 0.54 & 0.73 & 0.668 & NOK & OK & ACCEPT \\
\hline PERFvar163 <- 5PERF & 0.771 & 0.837 & 0.737 & OK & OK & OK \\
\hline PERFvar164 <- 5PERF & 0.704 & 0.765 & 0.668 & ACCEPT & OK & ACCEPT \\
\hline PERFvar165 <- 5PERF & 0.719 & 0.74 & 0.628 & OK & OK & ACCEPT \\
\hline
\end{tabular}

Table 11. Outer loading - Evaluation of the internal consistency of the performance items

\subsubsection{Performance. Verification of the measurement model. Stage 2 - Reliability of the} indicator

To evaluate the reliability of the construct, the composite reliability was assessed following a resampling (bootstrapping) process. As shown in Table 12, in all samples, it is above the acceptance criterion of 0.708 .

\begin{tabular}{|l|r|r|r|l|l|l|}
\cline { 2 - 6 } \multicolumn{1}{c|}{} & EEUU96 & EEUU99 & ESP97 & EEUU96 & EEUU99 & ESP97 \\
\hline 5PERF & 0.918 & 0.940 & 0.894 & OK & OK & OK \\
\hline
\end{tabular}

Table 12. Composite Reliability - Evaluation of the reliability of the performance construct 


\subsubsection{Performance. Verification of the measurement model. Stage 3 - Convergent validity}

In this stage, it was assessed whether the AVE was greater than 0.5 in each of the samples, as shown in Table 13.

\begin{tabular}{|l|r|r|r|l|l|l|}
\cline { 2 - 6 } \multicolumn{1}{c|}{} & EEUU96 & EEUU99 & ESP97 & EEUU96 & EEUU99 & ESP97 \\
\hline 5PERF & 0.531 & 0.613 & 0.459 & OK & OK & NOK \\
\hline
\end{tabular}

Table 13. AVE - Evaluation of the convergent validity of the performance construct

\subsubsection{Performance. Verification of the measurement model. Stage 4 - Discriminant validity}

The discriminant validity of the construct is evaluated in two stages, and in each, it can be seen that the loadings of the performance construct are greater than the rest, as shown in Table 14 and Table 15.

\begin{tabular}{|l|r|r|r|}
\cline { 2 - 4 } \multicolumn{1}{c|}{} & \multicolumn{1}{c|}{ EEUU96 } & \multicolumn{1}{c|}{ EEUU99 } & \multicolumn{1}{c|}{ ESP97 } \\
\hline 5PERF - 1INF & 0.195 & 0.259 & 0.289 \\
\hline 5PERF - 2TRA & 0.301 & 0.292 & 0.353 \\
\hline 5PERF - 3REW & 0.293 & 0.335 & 0.229 \\
\hline 5PERF - 4EMP & 0.407 & 0.443 & 0.297 \\
\hline 5PERF - 5PERF & 0.729 & 0.783 & 0.678 \\
\hline
\end{tabular}

Table 14. Evaluation of the discriminant validity - FORNELL-LACKER C

\begin{tabular}{|l|r|r|r|r|r|}
\hline AÑ 96 & \multicolumn{1}{|l|}{ 1INF } & \multicolumn{1}{l|}{ 2TRA } & \multicolumn{1}{l|}{ 3REW } & 4EMP & 5PERF \\
\hline PERFe210 & 0.142 & 0.214 & 0.222 & 0.267 & 0.717 \\
\hline PERFe211 & 0.144 & 0.183 & 0.235 & 0.28 & 0.688 \\
\hline PERFvar157 & 0.051 & 0.204 & 0.171 & 0.32 & 0.813 \\
\hline PERFvar158 & 0.106 & 0.264 & 0.23 & 0.327 & 0.786 \\
\hline PERFvar159 & 0.224 & 0.277 & 0.21 & 0.313 & 0.75 \\
\hline PERFvar160 & 0.158 & 0.243 & 0.202 & 0.343 & 0.765 \\
\hline PERFvar161 & 0.061 & -0.012 & 0.095 & 0.07 & 0.54 \\
\hline PERFvar163 & 0.182 & 0.241 & 0.259 & 0.339 & 0.771 \\
\hline PERFvar164 & 0.124 & 0.212 & 0.195 & 0.297 & 0.704 \\
\hline PERFvar165 & 0.193 & 0.222 & 0.266 & 0.278 & 0.719 \\
\hline
\end{tabular}

Table 15. Evaluation of the discriminant validity - CROSS LOADINGS 


\subsubsection{HIWP. Analysis of the second order construct}

In addition, and in order to evaluate the HIWP second order construct, the significance values for the first order constructs that make up the HIWP construct are shown in Table 16.

\begin{tabular}{|l|r|r|r|}
\hline \multicolumn{1}{|c|}{ Construct } & USA-1996 & USA-1999 & \multicolumn{1}{c|}{ Spain-1997 } \\
\hline COMMUNICATION-HIWP & 0.168 & 0.395 & 0.546 \\
\hline TRAINING-HIWP & 0.659 & 0.921 & 2.422 \\
\hline REWARDS-HIWP & 1.554 & 1.710 & 0.401 \\
\hline EMPOWERMENT-HIWP & 4.103 & 3.835 & 0.378 \\
\hline
\end{tabular}

Table 16. Evaluation of the significance (T-value) of the weights in the second order construct

As can be seen in this table, the relationship between the construct "participation" and the second order construct "HIWP" is significant in the samples USA-1996 and USA-1999, the relationship between "training" and "HIWP" is only significant in the sample Spain-1997, and the relationship between "rewards" and "HIWP" is only significant in the sample USA-1999, whereas the relationship between the construct "communication" and "HIWP" is not significant in any of the three samples.

These results, however, are not conclusive, since due to the way in which we have defined the second order construct (repetition of indicators), the number of items for each first order construct affects the weight in the second order construct (Hair, Ringle et al., 2013). In our case, there is an important difference in the number of items: communication has 5 items and training has 7 , while rewards and empowerment each have 9 .

This result should be verified in future studies, applying the two-stage method (Hair, Hult et al., 2013) in the definition of the HIWP second order construct to circumvent this problem detected when calculating the significance of the second order construct.

Even with these data in mind, Table 17 shows the weight values; the values above the mean in each sample have been indicated.

\begin{tabular}{|l|r|r|r|}
\hline \multicolumn{1}{|c|}{ Construct } & USA-1996 & USA-1999 & \multicolumn{1}{c|}{ Spain-1997 } \\
\hline COMMUNICATION-HIWP & 0.023 & 0.057 & 0.145 \\
\hline TRAINING-HIWP & 0.112 & 0.151 & 0.722 \\
\hline REWARDS-HIWP & 0.274 & 0.286 & 0.108 \\
\hline EMPOWERMENT-HIWP & 0.744 & 0.685 & 0.115 \\
\hline
\end{tabular}

Table 17. Evaluation of the weights in the second order construct 
From this table, we can see that the greatest incidence in the HIWP in the case of the samples from the USA comes from the construct "empowerment," while in the case of Spain, the construct with the greatest incidence is that of training, which is also the only construct that is significant in this series (see Table 16).

\subsection{Analysis of the results obtained in the verification of the measurement model}

The evaluation of the quality of the measurement instrument performed in the previous sections has shown:

- The performance construct does operate as a reflective model.

- With regard to the formative measurement model applied to the four first order constructs that make up the HIWP, the results obtained in the last stage of the verification shed doubt on the validity of some of the items associated with the rewards and empowerment constructs.

- In terms of the second order HIWP construct, it has been concluded that the methodology applied for its configuration (repetition of indicators) prevents us from obtaining conclusive data on the significance of each first order construct, and thus future studies should address this aspect.

Assuming that the model proposed in this work needs additional adjustments, which much be addressed in future studies, we propose continuing to evaluate the structural model in order to confirm the advisability of making these adjustments in the measurement model, with the aim of increasing the explained $\mathrm{R}^{2}$ of the structural model.

\subsection{Evaluation of the structural model}

In light of Hair, Ringle et al.'s recommendation (2013), we have proceeded to evaluate the structural model: the predictive power, the predictive relevance and the significance of the structural relationships, but the first step is to evaluate whether any collinearity exists among the constructs of the model. 


\subsubsection{Evaluation of the structural model. Step 1 - Evaluation of collinearity}

Applying the methodology described in the previous sections, it has been demonstrated that the VIF value of each of the constructs and for each of the samples is less than 5, thus confirming the lack of collinearity among the different constructs of the model (Table 18).

\begin{tabular}{|c|c|c|c|c|c|}
\hline \multicolumn{2}{|l|}{ USA-1996 } & \multicolumn{2}{|c|}{ USA-1999 } & \multicolumn{2}{|c|}{ Spain-1997 } \\
\hline Construct & VIF & Construct & VIF & Construct & VIF \\
\hline COMMUNICATION & 1.325 & COMMUNICATION & 1.492 & COMMUNICATION & 2.247 \\
\hline TRAINING & 1.850 & TRAINING & 1.565 & TRAINING & 3.521 \\
\hline REWARDS & 1.370 & REWARDS & 1.406 & REWARDS & 1.585 \\
\hline EMPOWERMENT & 1.797 & EMPOWERMENT & 1.721 & EMPOWERMENT & 2.718 \\
\hline
\end{tabular}

Table 18. Evaluation of the collinearity of the structural model

\subsubsection{Evaluation of the structural model. Step 2 - Path coefficients of the structural model}

We have obtained the significance of the path coefficient from the $\mathrm{T}$ statistics, after running the bootstrapping resampling. See Table 19 and Figure 3, Figure 4 and Figure 5.

\begin{tabular}{|c|r|r|r|}
\hline Construct & EEUU1996 & EEUU1999 & \multicolumn{1}{c|}{ Spain1997 } \\
\hline HIWP-PERFORMANCE & 9.066 & 10.594 & 4.734 \\
\hline
\end{tabular}

Table 19. Evaluation of the significance (T-value) of the path coefficient in the structural model

These data evidence that the relationship between the second order construct "HIWP" and performanceis relevant, as indicated in the corresponding theoretical literature, since the path between the second order construct and performance is significant.

Next, we evaluate (Table 20) the value of the path coefficient (direct effect) between the second order construct "HIWP" and performance, which gives us information about the relative importance of this relationship. As shown in this table, this data item is lower in the Spanish sample than in the samples from the USA. However, all are in the same order of magnitude, showing a moderate-weak relationship between the two constructs.

\begin{tabular}{|c|r|r|r|}
\hline Construct & EEUU1996 & EEUU1999 & Spain1997 \\
\hline HIWP - PERFORMANCE & 0.454 & 0.536 & 0.399 \\
\hline
\end{tabular}

Table 20. Evaluation of the path coefficients in the structural model 


\subsubsection{Evaluation of the structural model. Step 3 - Coefficient of determination $\left(\mathbf{R}^{2}\right.$ value)}

In this stage, we propose to estimate the amount of variance in the dependent constructs, in this case, the construct "performance", which is explained by the model's preceding constructs, by means of the $\mathrm{R}^{2}$ value.

The minimum recommended value is $10 \%$, and according to Hair, Hult et al. (2013), values greater than $75 \%$ would provide a substantial explanation; 50\%, a moderate explanation; and 25\%, a weak explanation.

With regard to the $\mathrm{R}^{2}$ value obtained, the following is worthy of special note (see Table 21, Figure 6, Figure 7 and Figure 8):

- In the 3 samples, a weak effect of the HIWP practices has been detected on the measured performance.

- A much greater explained variance value has been detected in the sample USA-1999.

\begin{tabular}{|l|r|r|r|}
\cline { 2 - 4 } \multicolumn{1}{c|}{} & $\mathbf{R}^{2}$ - YEAR 96 & $\mathbf{R}^{2}$ - YEAR 99 & $\mathbf{R}^{2}$ - YEAR 97 \\
\hline PERFORMANCE & 0.206 & 0.288 & 0.159 \\
\hline
\end{tabular}

Table 21. $\mathrm{R}^{2}$ of the dependent variable (performance construct) for the three samples analyzed 


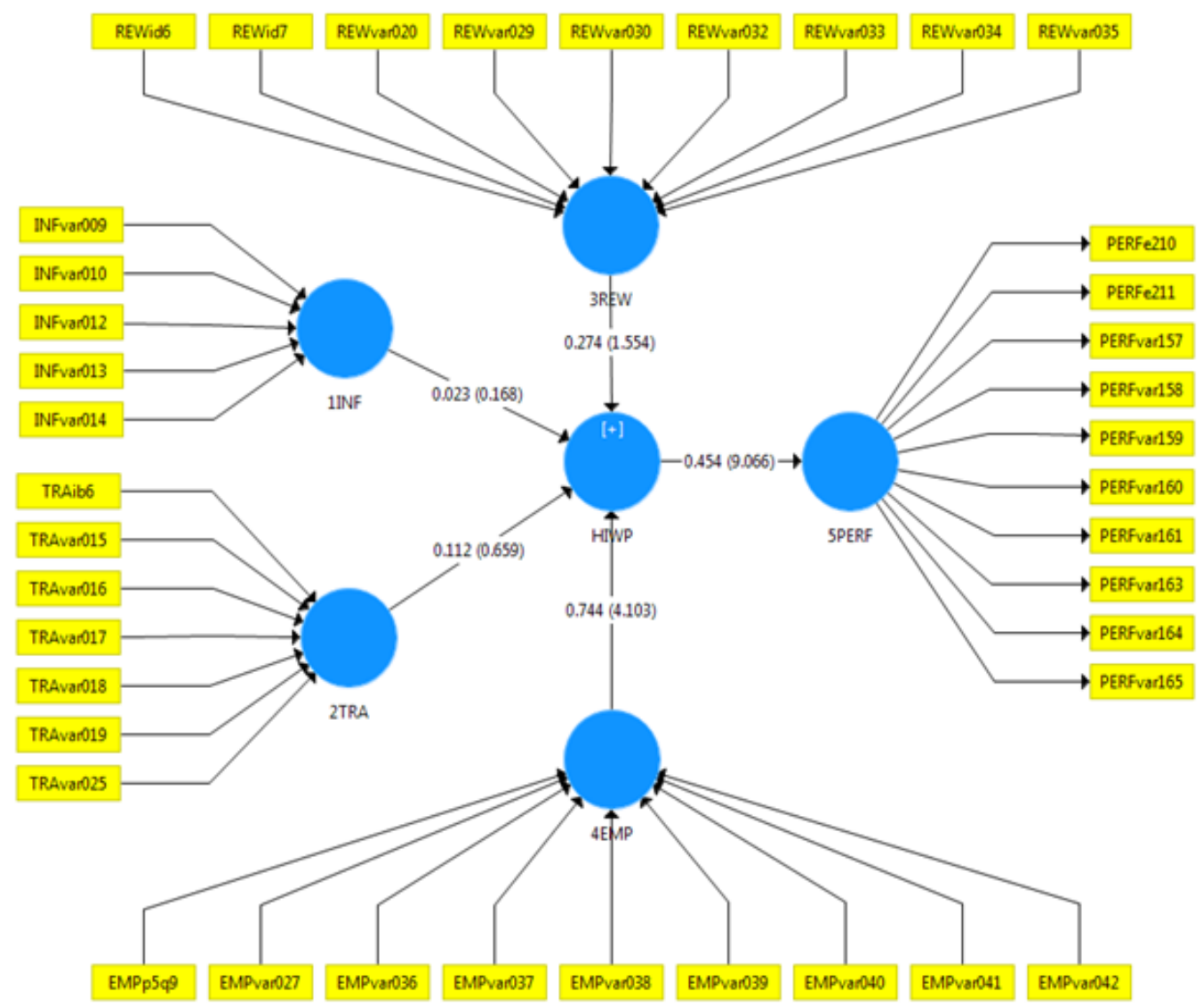

Figure 3. Sample USA-1996. Significance (T-value) and path coefficient of the structural model 


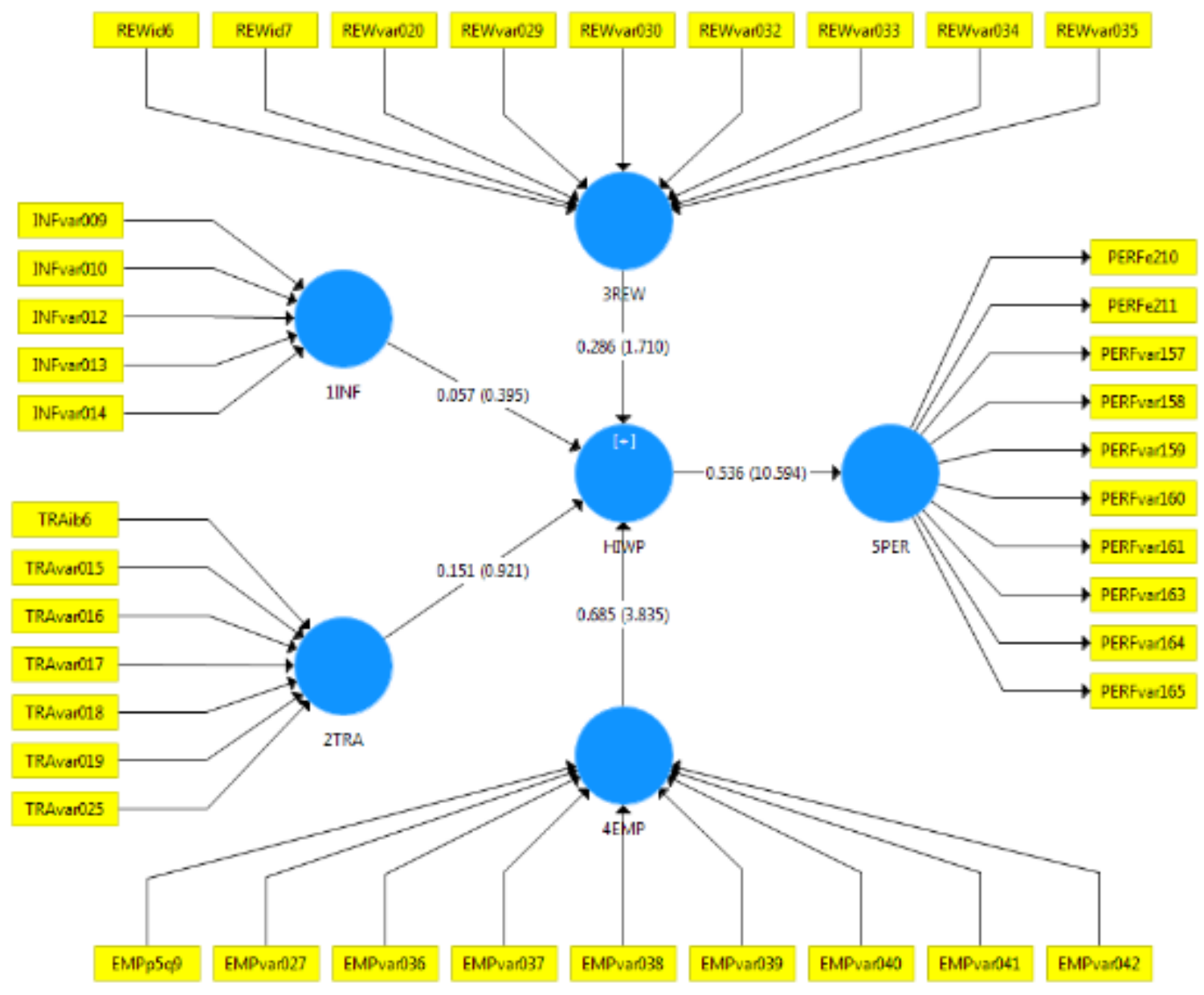

Figure 4. Sample USA-1996. Significance (T-value) and path coefficient of the structural model 


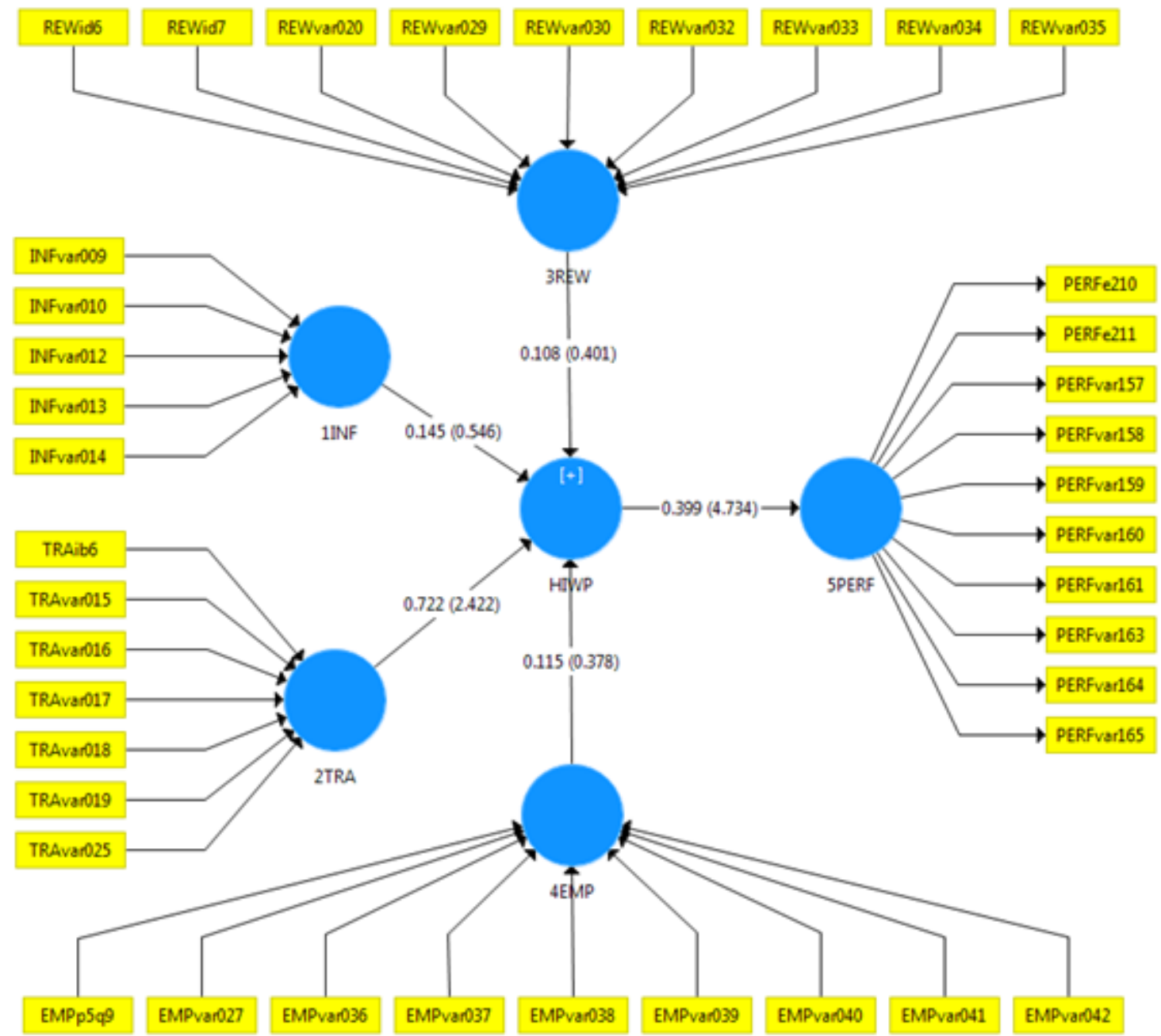

Figure 5. Sample Spain-1997. Significance (T-value) and path coefficient of the structural model 


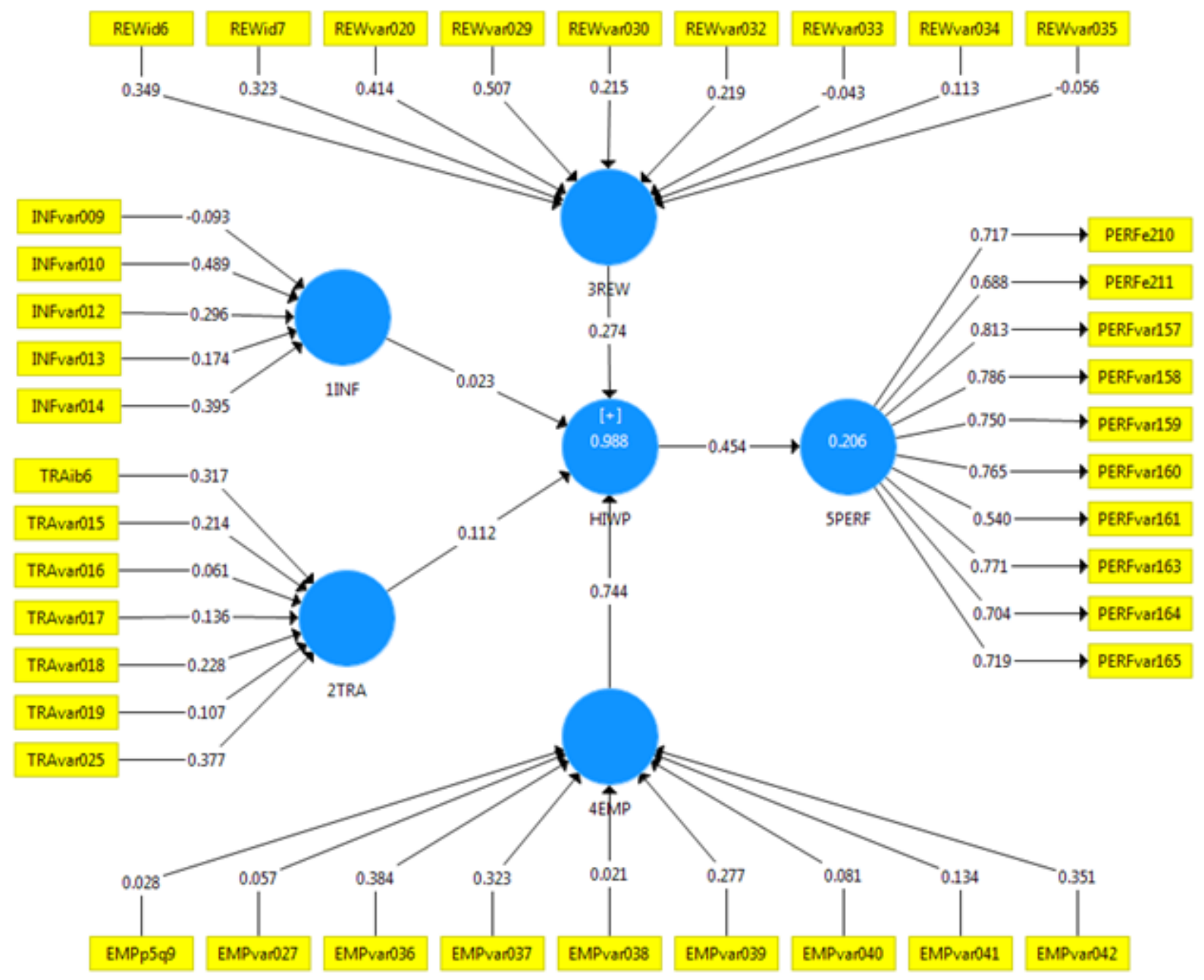

Figure 6. Sample USA-1996. Path coefficient of the structural model and weights/loads of the measurement model 


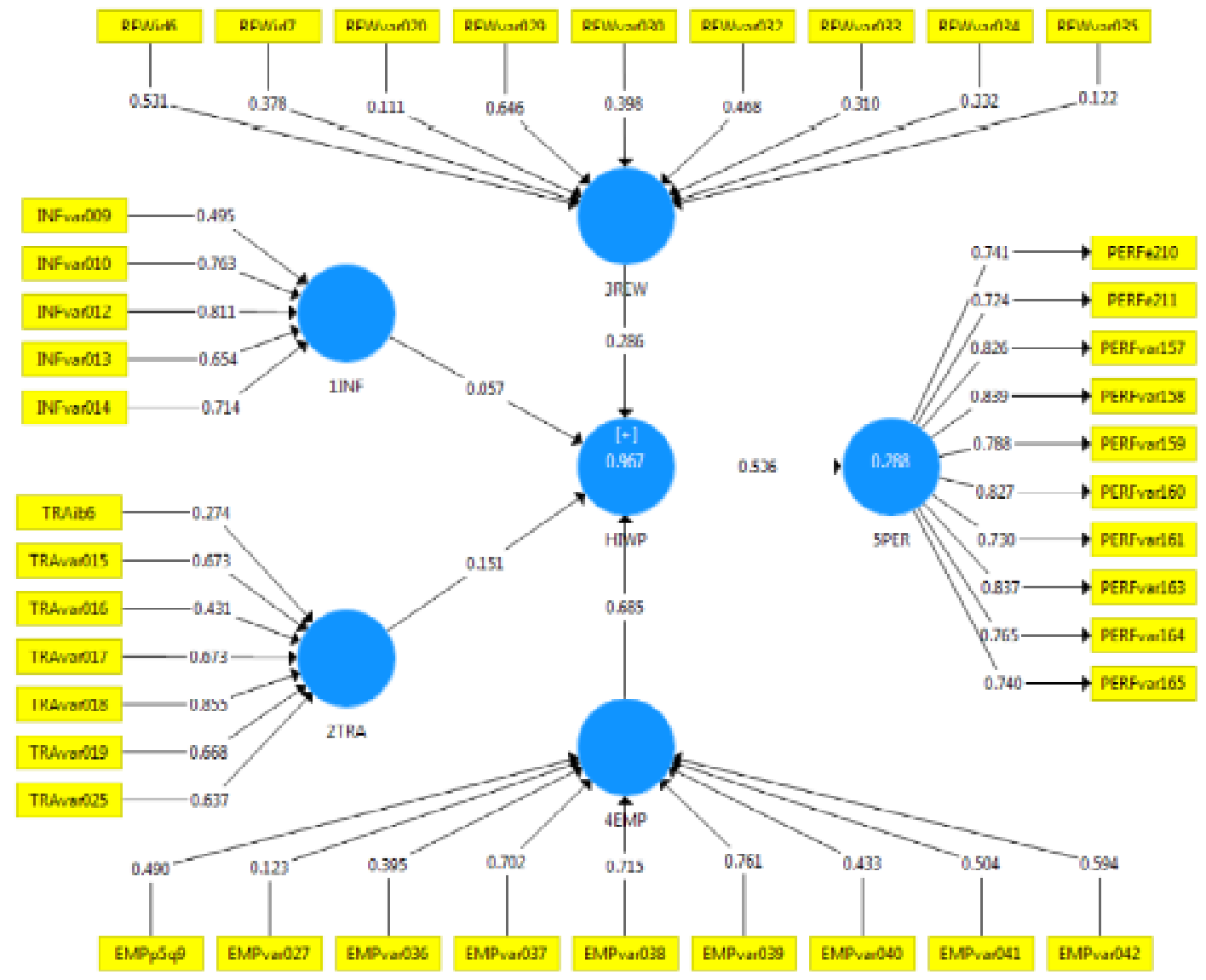

Figure 7. Sample USA-1999. Path coefficient of the structural model and weights/loads of the measurement model 


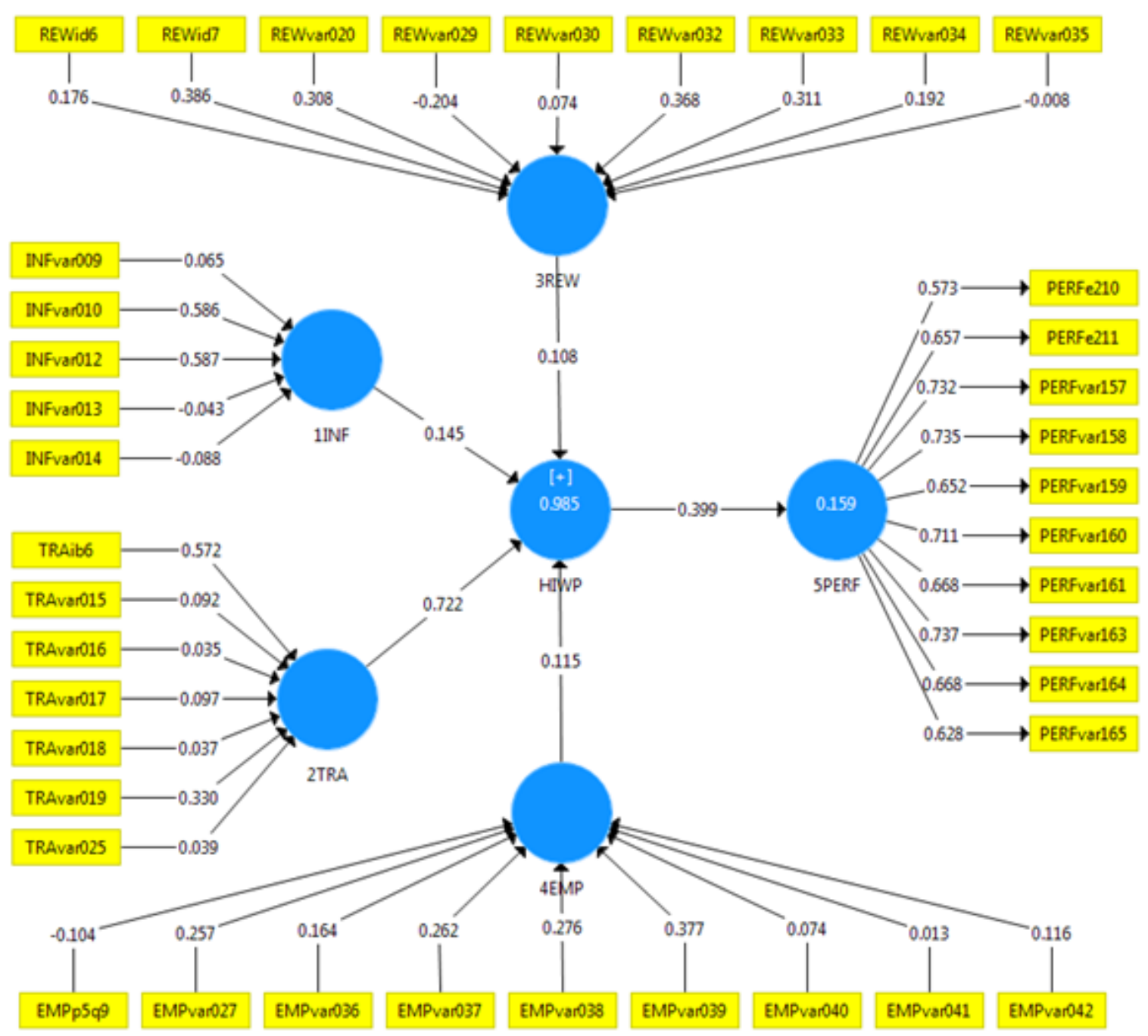

Figure 8. Sample Spain-1997. Path coefficient of the structural model and weights/loads of the measurement model

Furthermore, by examining the weights of each of the items in their first order constructs, we can identify the programs that have the most effect in order to explain performance. These have been marked in green in Table 22, indicating the weights that are above the mean for the items of a construct in each sample. 


\begin{tabular}{|c|c|c|c|c|c|c|c|c|c|c|c|c|}
\hline & \multicolumn{3}{|c|}{ 1INF } & \multicolumn{3}{|c|}{ 2TRA } & \multicolumn{3}{|c|}{ 3REW } & \multicolumn{3}{|c|}{ 4EMP } \\
\hline & 96 & 99 & 97 & 96 & 99 & 97 & 96 & 99 & 97 & 96 & 99 & 97 \\
\hline INFvar009 & -0.093 & -0.182 & 0.065 & & & & & & & & & \\
\hline INFvar010 & 0.489 & 0.513 & 0.586 & & & & & & & & & \\
\hline INFvar012 & 0.296 & 0.410 & 0.587 & & & & & & & & & \\
\hline INFvar013 & 0.174 & 0.109 & -0.043 & & & & & & & & & \\
\hline INFvar014 & 0.395 & 0.413 & -0.088 & & & & & & & & & \\
\hline TRAib6 & & & & 0.317 & -0.134 & 0.572 & & & & & & \\
\hline TRAvar015 & & & & 0.214 & -0.022 & 0.092 & & & & & & \\
\hline TRAvar016 & & & & 0.061 & -0.100 & 0.035 & & & & & & \\
\hline TRAvar017 & & & & 0.136 & 0.308 & 0.097 & & & & & & \\
\hline TRAvar018 & & & & 0.228 & 0.577 & 0.037 & & & & & & \\
\hline TRAvar019 & & & & 0.107 & 0.320 & 0.330 & & & & & & \\
\hline TRAvar025 & & & & 0.377 & 0.283 & 0.039 & & & & & & \\
\hline REWid6 & & & & & & & 0.349 & 0.417 & 0.176 & & & \\
\hline REWid7 & & & & & & & 0.323 & 0.305 & 0.386 & & & \\
\hline REWvar020 & & & & & & & 0.414 & 0.045 & 0.308 & & & \\
\hline REWvar029 & & & & & & & 0.507 & 0.612 & -0.204 & & & \\
\hline REWvar030 & & & & & & & 0.215 & 0.289 & 0.074 & & & \\
\hline REWvar032 & & & & & & & 0.219 & 0.282 & 0.368 & & & \\
\hline REWvar033 & & & & & & & -0.043 & -0.010 & 0.311 & & & \\
\hline REWvar034 & & & & & & & 0.113 & 0.116 & 0.192 & & & \\
\hline REWvar035 & & & & & & & -0.056 & -0.161 & -0.008 & & & \\
\hline EMPp5q9 & & & & & & & & & & 0.028 & 0.151 & -0.104 \\
\hline EMPvar027 & & & & & & & & & & 0.057 & -0.061 & 0.257 \\
\hline EMPvar036 & & & & & & & & & & 0.384 & 0.155 & 0.164 \\
\hline EMPvar037 & & & & & & & & & & 0.323 & 0.210 & 0.262 \\
\hline EMPvar038 & & & & & & & & & & 0.021 & 0.350 & 0.276 \\
\hline EMPvar039 & & & & & & & & & & 0.277 & 0.329 & 0.377 \\
\hline EMPvar040 & & & & & & & & & & 0.081 & 0.204 & 0.074 \\
\hline EMPvar041 & & & & & & & & & & 0.134 & 0.092 & 0.013 \\
\hline EMPvar042 & & & & & & & & & & 0.351 & 0.150 & 0.116 \\
\hline
\end{tabular}

Table 22. Weight of the constructs

In summary, with regard to the analysis of the structural model, we have obtained the following results:

- The path coefficient between the HIWP and performance in the 3 samples is significant, although since the measurement model could not be fully validated, this result is inconclusive.

- In the samples from the USA, the construct that has the greatest relative importance in the HIWP construct is "empowerment," while in the Spanish sample it is "training."

- With regard to the individual practices that have the greatest impact on performance:

- In "communication": INFvar010 (information on department results) and INFvar012 (information on new technologies)

- In "training": In the case of the USA, the following stand out: TRAvar018 (statistical analysis/quality) and TRAvar025 (training for other areas or positions in the company), 
while in Spain, they are: TRAib6 (training in skills for your own job) and TRAvar019 (work team training)

○ In "rewards": REWid7 (non-monetary compensation)

- In "empowerment": EMPvar037 (enrichment or redesign of the job position) and EMPvar039 (other groups of participation different form quality circles)

- With regard to the amount of variance for performance that is explained by the use of HIWP, we have found a weak relationship in the samples from the USA $(>0.2)$, while in the sample from Spain, the relationship is very low (0.16).

\section{Conclusions, limitations and future research}

The aims of this work were focused on verifying the HIWP measurement model on Lawler's (Lawler III, 1986) questionnaire as a formative model, in order to then analyze its predictive capacity.

With regard to the first objective, from an academic perspective, with this work we have verified that the scale of measurement of a second order construct for the HIWP is not entirely appropriate. The main problem arises in two of the first order constructs, and thus it is proposed for future research to improve the reward and empowerment scales, dividing each of the constructs, originally conceived as unidimensional, into two more homogeneous sub-constructs. Furthermore, this study should consider the configuration of the second order construct, applying the two-stage method, instead of the item repetition method that has been applied in this study.

On the other hand, in relation to the second objective, our study confirms the significant, although weak, relationship between the use of HIWP and company results, which in our model are measured through the perceived results. Even though this relationship exists, it is based on a measurement model that on a methodological level has not been full validated, and must be confirmed by future research.

In the case that this relationship is ultimately confirmed, the finding is important for professional fields, as it quantifies the relationship between the use of HIWP and performance in two countries with important cultural differences and it also identifies the practices that contribute to the greatest extent to this positive relationship. 
In a general sense, this work contributes to the debate surrounding the HIWP-results relationship, indicating the possible predictive capacity of the Lawler model to measure the effect of the use of HIWP on the results of companies, based on a measurement model that presents formative relationships.

However, the limitations of this study must be kept in mind when considering these contributions. First of all, our data come from studies that are more than 15 years old, although for the purposes of testing the measurement models, the contemporaneity of the data is not an important limitation, given that we analyze the relationship between the constructs and we are not interested in describing the status of the evolution of these practices, rather how we can measure the specified relationship.

Additionally, we only have data from large companies in two countries, and thus we cannot generalize the conclusions to other contexts. Furthermore, the data used come from cross-sectional studies, which may mean that some of the effects derived from the use of HIWP are not detected, which over time, are important for the generation of results. Finally, the fact that the responses to the questionnaire come from a single source of information (management), instead of consulting other company informants, as other authors have suggested (Bowen \& Ostroff, 2004; Guest, 2011; Nishii, Lepak \& Schneider, 2008; Paul \& Anantharaman, 2003), could represent a limitation in the validity of the conclusions reached.

The proposals for future lines of research primarily have a direct relationship to the limitations set out above. Therefore, firstly, it would be interesting to improve the initial model in terms of the rewards and empowerment scales, dividing the constructs originally conceived as unidimensional into two more homogeneous constructs, and re-verifying its validity. With regard to the trans-cultural nature of the model, performing a multi-group analysis would allow us to determine whether the measurement model is consistent enough to be used in different cultural contexts. Finally, conducting longitudinal studies is an important challenge in the field of HIWP. 


\section{References}

Arthur, J.B. (1994). Effects of human resource systems on manufacturing performance and turnover. Academy of management Journal, 37(3), 670-687. Retrieved from: http://search.ebscohost.com/login.aspx?

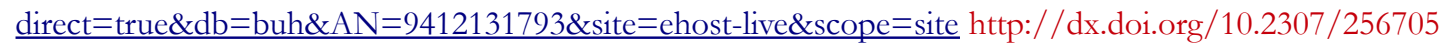

Barroso Castro, M.C., Cepeda Carrión, G.A., \& Roldán Salgueiro, J.L. (2007). Constructos latentes y agregados en la economía de la empresa. Asociación Española de Dirección y Economía de la Empresa (AEDEM). Retrieved from: http://dialnet.unirioja.es/servlet/oaiart?codigo $=2487672$

Becker, B.E., \& Huselid, M.A. (2006). Strategic human resources management: Where do we go from here?. Journal of management, 32(6), 898-925. http://dx.doi.org/10.1177/0149206306293668

Benson, G.S., Young, S.M., \& Lawler III, E.E. (2006). High-involvement work practices and analysts' forecasts of corporate earnings. Human resource management, 45(4), 519-537. Retrieved from Wiley Subscription Services, Inc., A Wiley Company. http://dx.doi.org/10.1002/hrm.20130

Boselie, P., Dietz, G., \& Boon, C. (2005). Commonalities and contradictions in HRM and performance research. Human Resource Management Journal, 15(3), 67-94. Retrieved from Wiley-Blackwell: http://search.ebscohost.com/login.aspx?direct=true\&db=buh\&AN=17649112\&site=ehost-live\&scope=site http://dx.doi.org/10.1111/j.1748-8583.2005.tb00154.x

Bowen, D.E., \& Ostroff, C. (2004). Understanding HRM-Firm Performance Linkages: The Role of the "Strengt" of the HRM System. Academy of Management Review, 29(2), 203-221. Retrieved from: http://amr.aom.org/content/29/2/203.abstract

Boxall, P. (2012). High-performance work systems: What, why, how and for whom?. Asia Pacific Journal of Human Resources, 50(2), 169-186. http://dx.doi.org/10.1111/j.1744-7941.2011.00012.x

Camps, J., \& Luna-Arocas, R. (2009). High involvement work practices and firm performance. International journal of buman resource management, 20(5), 1056-1077. Retrieved from Routledge: http://search.ebscohost.com/login.aspx?direct $=$ true\&db=buh\&AN=40628014\&site=ehost-live\&scope=site http://dx.doi.org/10.1080/09585190902850273

Cappelli, P., \& Neumark, D. (2001). Do "High-Performance" Work Practices Improve EstablishmentLevel Outcomes?. Industrial \& Labor Relations Review, 54(4), 737-775. Retrieved from: http://ilt.sagepub.com/content/54/4/737.abstract http://dx.doi.org/10.1177/001979390105400401

Cepeda, G., \& Roldán, J.L. (2004). Aplicando en la práctica la técnica PLS en la administración de empresas. Conocimiento y Competitividad. XIV Congreso Nacional ACEDE.Murcia (pp. 74-78). 
Combs, J., Liu, Y.M., Hall, A., \& Ketchen, D. (2006). How much do high-performance work practices matter? A meta-analysis of their effects on organizational performance. Personnel psychology, 59(3), 501-528. http://dx.doi.org/10.1111/j.1744-6570.2006.00045.x

Conci, G. (2012). Perceived results obtained by companies associated to the use of high involvement work practices (HIWP). Working Papers on Operations Management, 3(1), 01-15. Retrieved from: http://ojs.upv.es/index.php/WPOM/article/view/1065 http://dx.doi.org/10.4995/wpom.v3i1.1065

Coye, R.W., \& Belohlav, J.A. (1995). An Exploratory Analysis of Employee Participation. Group \& Organization Management, 20(1), 4-17. Retrieved from: http://gom.sagepub.com/content/20/1/4.abstract http://dx.doi.org/10.1177/1059601195201002

Datta, D.K., Guthrie, J.P., \& Wright, P.M. (2005). Human Resource Management and Labor Productivity: Does Industry Matter?. Academy of management Journal, 48(1), 135-145. Retrieved from: http://amj.aom.org/content/48/1/135.abstract http://dx.doi.org/10.5465/AMJ.2005.15993158

Drehmer, D.E., Belohlav, J.A., \& Coye, R.W. (2000). An Exploration of Employee Participation Using a Scaling Approach. Group \& Organization Management, 25(4), 397-418. Retrieved from: http://gom.sagepub.com/content/25/4/397.abstract http://dx.doi.org/10.1177/1059601100254005

Ericksen, J.E.F. (2007). High performance work systems, dynamic workforce alignment, and firm performance. Academy of Management Annual Meeting Proceedings (pp. 1-6) Academy of Management. http://dx.doi.org/10.5465/AMBPP.2007.26518272

Guerrero, S., \& Barraud-Didier, V. (2004). High-involvement practices and performance of French firms. International journal of buman resource management, 15(8), 1408-1423. http://dx.doi.org/10.1080/0958519042000258002

Guest, D.E. (2011). Human resource management and performance: still searching for some answers. Human Resource Management Journal, 21(1), 3-13. Retrieved from Blackwell Publishing Ltd. http://dx.doi.org/10.1111/j.1748-8583.2010.00164.x

Guthrie, J.P. (2001). High-involvement work practices, turnover, and productivity: Evidence from New Zealand. Academy of management Journal, 44(1), 180-190. http://dx.doi.org/10.2307/3069345

Guthrie, J.P., Spell, C.S., \& Nyamori, R.O. (2002). Correlates and consequences of high involvement work practices: The role of competitive strategy. International journal of human resource management, 13(1), 183-197. http://dx.doi.org/10.1080/09585190110085071

Hair, J.F. Jr., Hult, G.T.M., Ringle, C., \& Sarstedt, M. (2013). A Primer on Partial Least Squares Structural Equation Modeling (PLS-SEM). Thousand Oaks: Sage Publishing. ISBN 9781452217444 
Hair, J., Ringle, C.M., \& Sarstedt, M. (2013). Partial Least Squares Structural Equation Modeling: Rigorous Applications, Better Results and Higher Acceptance. Long Range Planning, 46(1GÇô2), 1-12. Retrieved from: http://www.sciencedirect.com/science/article/pii/S0024630113000022 http://dx.doi.org/10.1016/j.lrp.2013.01.001

Huselid, M.A. (1995). The impact of human-resource management-practices on turnover, productivity, and corporate financial performance. Academy of management Journal, 38(3), 635-672. http://dx.doi.org/10.2307/256741

Huselid, M.A., \& Becker, B.E. (1996). Methodological issues in cross-sectional and panel estimates of the human resource-firm performance link. Industrial relations, 35(3), 400-422. http://dx.doi.org/10.1111/j.1468-232x.1996.tb00413.x

Jarvis, C., Mackenzie, S., \& Podsakoff, P. (2003). A Critical Review of Construct Indicators and Measurement Model Misspecification in Marketing and Consumer Research. Journal of Consumer Research, 30(2), 199-218. http://dx.doi.org/10.1086/376806

Jiang, K., Lepak, D.P., Hu, J., \& Baer, J.C. (2012). How Does Human Resource Management Influence Organizational Outcomes? A Meta-analytic Investigation of Mediating Mechanisms. Academy of management Journal, 55(6), 1264-1294. Retrieved from: http://ami.aom.org/content/55/6/1264.abstract http://dx.doi.org/10.5465/amj.2011.0088

Jiang, K., Takeuchi, R., \& Lepak, D.P. (2013). Where do We Go From Here? New Perspectives on the Black Box in Strategic Human Resource Management Research. Journal of management studies, 50(8), 1448-1480. http://dx.doi.org/10.1111/joms.12057

Lawler III, E.E. (1986). High-Involvement Management. Participative Strategies for Improving Organizational Performance. Jossey-Bass Inc., Publishers.

Lawler, E.E. (2005). From human resource management to organizational effectiveness. Human resource management, 44(2), 165-169. Retrieved from Wiley Subscription Services, Inc., A Wiley Company. http://dx.doi.org/10.1002/hrm.20059

Lawler III, E.E., Mohrman, S., \& Benson, G. (2001). Organizing for high performance: Employee involvement, TQM, reengineering, and knowledge management in the fortune 1000. The CEO report Jossey-Bass.

Lawler III, E.E., Mohrman, S., \& Ledford, G. (1998). Strategies for high performance organizations: Employee involvement, TQM, and reengineering programs in fortune 1000 coporations. Jossey-Bass. 
Marin-Garcia, J.A. (2013). ¿Qué sabemos sobre la relación de los programas de recursos humanos de alto rendimiento y el desempeño organizativo? (What do we know about the relationship between High Involvement Work Practices and Performance? WPOM - Working Papers On Operations Management, 4(2), 01-15. http://dx.doi.org/10.4995/wpom.v4i2.1552. Retrieved from: http://ojs.upv.es/index.php/WPOM/article/view/1552

Marin-Garcia, J.A., Bonavía Martín, T., \& Miralles Insa, C. (2008). The use of employee participation in the USA and Spanish companies. International Journal of Management Scienceand Engineering Management, 3(1), 71-80. Retrieved from: http://www.worldacademicunion.com/journal/MSEM/online.htm

Marin-Garcia, J.A., \& Conci, G. (2009). Exploratory study of high involvement work practices: Identification of the dimensions and proposal of questionnaire to measure the degree of use in the company. Intangible Capital, 5(3), 278-300. http://dx.doi.org/10.3926/ic.2009.v5n3.p278-300

Marin-Garcia, J.A., \& Conci, G. (2010). Análisis factorial exploratorio para identificar las dimensiones subyacentes de los constructos de remuneración y participación. Working Papers on Operations Management, 1(1), 46-55. http://dx.doi.org/10.4995/wpom.v1i1.795

Marin-Garcia, J.A., \& Conci, G. (2012). Verification of the reflective model of first order factors for reward and empowerment constructs based on questionnaires derived from Lawler et al. (1991). Journal of Industrial Engineering and Management, 5(2), 473-495. http://dx.doi.org/10.3926/jiem.454

Marin-Garcia, J.A., \& Conci, G. (2013). Validación de un cuestionario para medir el grado de uso de las prácticas de alta implicación de los trabajadores. Intangible capital, 9(3), 854-882. Retrieved from: http://www.raco.cat/index.php/Intangible/article/view/273491

Nishii, L.H., Lepak, D.P., \& Schneider, B. (2008). Employee attributions of the "why" of HR practices: Their effects on employee attitudes and behaviors, and customer satisfaction. Personnel Psychology, 61(3), 503-545. http://dx.doi.org/10.1111/j.1744-6570.2008.00121.x. Retrieved from: http://www.scopus.com/inward/record.url?eid=2-s2.049149130883\&partnerID $=40 \& \mathrm{md} 5=\mathrm{b} 3 e e f 8 \mathrm{~b} 1 \mathrm{cdffac} 81 \mathrm{f} 10451 \mathrm{~d} 18217639 \mathrm{~b}$

Paul, A.K., \& Anantharaman, R.N. (2003). Impact of people management practices on organizational performance: Analysis of a causal model. International journal of buman resource management, 14(7), 1246-1266. http://dx.doi.org/10.1080/0958519032000145648. Retrieved from Routledge: http://search.ebscohost.com/login.aspx?direct $=$ true\&db=buh\&AN=10917483\&site=ehost-live\&scope $=$ site

Ringle, C.M., Wende, S., \& Becker, J.-M. (2015). SmartPLS 3.2.3 (Version 3.2.3). Retrieved from: http://www.smartpls.com 
Subramony, M. (2009). A meta-analytic investigation of the relationship between HRM bundles and firm performance. Human resource management, 48(5), 745-768. Retrieved from: http://search.ebscohost.com/login.aspx?direct=true\&db=buh\&AN=44435603\&site=ehost-live\&scope=site http:/ /dx.doi.org/10.1002/hrm.20315

Wright, P.M., Gardner, T.M., Moynihan, L.M., \& Allen, M.R. (2005). The relationship between HR practices and firm performance: Examining causal order. Personnel psychology, 58(2), 409-446. http://dx.doi.org/10.1111/j.1744-6570.2005.00487.x

Yu, C., Finegold, D., Lawler, E., \& Cochran, D. (2000). Does cultural fit matter? The adoption and effectiveness of employee involvement practices in China and the United States. Current Topics In Management, 5, 283-304.

Zheng, C., Morrison, M., \& O'Neill, G. (2006). An empirical study of high performance HRM practices in Chinese SMEs. International journal of buman resource management, 17(10), 1772-1803. http://dx.doi.org/10.1080/09585190600965282. Retrieved from Routledge: http://search.ebscohost.com/login.aspx?direct=true\&db=buh\&AN=22832862\&site=ehost-live\&scope=site

\section{APPENDIX I: Indicators used to measure the constructs}

\begin{tabular}{|c|c|}
\hline $\begin{array}{l}\text { Indique cuántos de los trabajadores de su empresa están } \\
\text { en la actualidad participando directamente en cada uno } \\
\text { de los siguientes programas: }\end{array}$ & $\begin{array}{l}\text { About how many of your corporation's employees are } \\
\text { currently involved in each of the following activities } \\
\text { or programs? }\end{array}$ \\
\hline EMPp5q9 Comités de consulta & Emp committee concerned with policy and/or stategy \\
\hline EMPvar027 Sistemas de sugerencias individuales & Suggestion system \\
\hline Encuestas de opinión & Survey feedback \\
\hline $\begin{array}{l}\text { EMPvar037 Enriquecimiento o rediseño del puesto de } \\
\text { trabajo }\end{array}$ & Job enrichment or redesign \\
\hline EMPvar038 Círculos de Calidad & Quality circles \\
\hline $\begin{array}{l}\text { EMPvar039 Otros grupos de sugerencias diferentes de } \\
\text { Círculos de Calidad }\end{array}$ & Employee participation groups other than quality circles \\
\hline EMPvar040 Comités de empresa o negociación colectiva. & Union-management QWL committees \\
\hline Mini-empresas & Mini-business units \\
\hline Grupos de trabajo semiautónomo & Self-managing workteams \\
\hline $\begin{array}{l}\text { ¿Cuántos de los trabajadores de la empresa reciben de } \\
\text { forma habitual información sobre...? }\end{array}$ & $\begin{array}{l}\text { About how many corporation employees are routinely } \\
\text { provided with the following types of information? }\end{array}$ \\
\hline Resultados operativos globales de la empresa & Info on corps overall operating results \\
\hline Resultados del departamento & Info on units operating results \\
\hline Nuevas tecnologías que pueden afectarles. & Advance info on new technologies \\
\hline Objetivos y planes del negocio & Info on business plans/goals \\
\hline $\begin{array}{l}\text { INFvar014 Comparación con el desempeño de la } \\
\text { competencia }\end{array}$ & Info on competitors' relative performance \\
\hline
\end{tabular}




\begin{tabular}{|c|c|}
\hline $\begin{array}{l}\text { Indique a cuántos de los trabajadores de la empresa se } \\
\text { les aplica cada uno de estos sistemas de remuneración o } \\
\text { recompensa: }\end{array}$ & $\begin{array}{l}\text { About how many employees are covered by a } \\
\text { pay/reward system with each of the following } \\
\text { elements? }\end{array}$ \\
\hline $\begin{array}{l}\text { REWid6 Complemento por logro de metas u objetivos } \\
\text { de grupo }\end{array}$ & Work Group or Team incentive \\
\hline Recompensas no monetarias & Non-monetary awards for performance \\
\hline REWvar020 Seguridad en el empleo & Employment security \\
\hline $\begin{array}{l}\text { REWvar029 Complemento de sueldo en función de las } \\
\text { habilidades y conocimientos del trabajador }\end{array}$ & Knowledge/SBP \\
\hline REWvar030 $\quad$ Reparto de beneficios de la empresa & Profit sharing \\
\hline $\begin{array}{l}\text { REWvar032 Reparto de ganancias por sugerencias } \\
\text { aportadas }\end{array}$ & Gain sharing \\
\hline $\begin{array}{l}\text { REWvar033 Complemento por logro de metas u objetivos } \\
\text { individuales }\end{array}$ & Individual incentive \\
\hline REWvar034 Participación en el capital de la compañía & Stock option plan \\
\hline Remuneración flexible/pago en especie & Flexible cafeteria-style benefits \\
\hline $\begin{array}{l}\text { ¿Cuántos de sus trabajadores han recibido, en los } \\
\text { últimos } 3 \text { años, formación sistemática y programada } \\
\text { en ...? }\end{array}$ & $\begin{array}{l}\text { About how many corporation employees have } \\
\text { received, within the past } 3 \text { years, systematic, formal } \\
\text { training on the following } \\
\text { types of skills? }\end{array}$ \\
\hline $\begin{array}{l}\text { TRAib6 Entrenamiento en las habilidades de su propio } \\
\text { trabajo }\end{array}$ & Training in job skills training \\
\hline $\begin{array}{l}\text { TRAvar015 Toma de decisiones/solución de problemas en } \\
\text { grupos }\end{array}$ & Training in group decision-making/problem-solving skills \\
\hline TRAvar016 Conocimientos de liderazgo & Training in leadership skills \\
\hline TRAvar017 Conocimientos de administración de empresas & Training in skills understanding the business \\
\hline TRAvar018 Análisis estadístico/calidad & Training in quality/statistical analysis skills \\
\hline TRAvar019 Formación de equipos de trabajo & Training in team building skills \\
\hline $\begin{array}{l}\text { TRAvar025 Formación para otras áreas o puestos de trabajo } \\
\text { de la.empresa }\end{array}$ & Training in cross training \\
\hline $\begin{array}{l}\text { ¿Cómo valora el impacto positivo o negativo, si existe, } \\
\text { que tienen los esfuerzos para lograr la implicación del } \\
\text { trabajador en los siguientes indicadores del rendimiento } \\
\text { de la empresa? }\end{array}$ & $\begin{array}{l}\text { How much of a negative or positive impact, if either, } \\
\text { have employee involvement efforts had on each of the } \\
\text { following performance indicators in your } \\
\text { corporation? }\end{array}$ \\
\hline PERFe210 Flexibilidad & Speed/flexibility \\
\hline Lealtad del trabajador & employee loyalty \\
\hline PERFvar157 Productividad & productivity \\
\hline PERFvar158 Calidad de los productos/servicios & quality of product or service \\
\hline PERFvar159 Atención al cliente & customer service \\
\hline PERFvar160 Satisfacción del trabajador & employee satisfaction \\
\hline PERFvar161 Rotación del personal & turnover \\
\hline PERFvar163 Competitividad & competitiveness \\
\hline PERFvar164 Beneficios & profitability \\
\hline PERFvar165 Calidad de vida en el trabajo & employee QWL \\
\hline
\end{tabular}




\section{Versión en español}

Título: Comprobación de un modelo de medida de High Involvement Work Programs (HIWP) y de su capacidad predictiva de los resultados percibidos por el mando

\section{Resumen}

Objeto: Uno de los objetivos del trabajo es la validación de un modelo de medida de los HIWP basado en el cuestionario original de Lawler (1986). Nuestra propuesta plantea un constructo formativo de segundo orden para los HIWP (High Involvement Workprograms), en el que los cuatro constructos de primer orden que caracterizan el modelo, Comunicación, Formación, Remuneración y Participación son constructos formativos.

Tras abordar la validación del modelo de medida, se comprueba también el modelo de estructura para evaluar la capacidad predictiva de los HIWP sobre el rendimiento empresarial en tres muestras distintas de diferentes países.

Diseño/metodología/enfoque: Para la validación del modelo de medida se utiliza una herramienta de ecuaciones estructurales por mínimos cuadrados parciales (PLS-SEM) y los datos obtenidos por los investigadores que desarrollaron las versiones oficiales del cuestionario en inglés y castellano.

Aportaciones y resultados: En general, este trabajo contribuye al debate que gira en torno a la relación HIWP-resultados, apuntando a una posible capacidad predictiva del modelo de Lawler para medir el efecto del uso de los HIWP sobre los resultados de las empresas, partiendo de un modelo de medida que presenta relaciones formativas. Nuestro estudio confirma la relación significativa, aunque baja, entre el uso de los HIWP y los resultados en la empresa, que en nuestro modelo se miden a través de resultados percibidos. Aunque la existencia de esta relación, que parte de un modelo de medida que a nivel metodológico no se ha validado completamente, debe confirmarse en investigaciones futuras.

Limitaciones: Estas contribuciones deben considerarse teniendo en cuenta las limitaciones de la investigación. En primer lugar, nuestros datos provienen de estudios de hace más de 15 años, aunque para probar los modelos de medida la vigencia de los datos no es una limitación importante puesto que analizamos la relación entre los constructos y no nos interesa describir el estado de evolución de estas prácticas, sino cómo poder medir esta relación definida. 
Por otra parte, sólo disponemos de datos de empresas grandes de dos países por lo que no podemos generalizar las conclusiones a otros contextos.

Originalidad / Valor añadido: De ser así, y confirmarse definitivamente esta relación, el hallazgo es importante para el entorno profesional, ya que cuantifica la relación entre el uso de los HIWP y la performance en dos países con importantes diferencias culturales, y además identifica las prácticas que contribuyen en mayor medida a esta relación positiva.

Palabras clave: RRHH, Recursos humanos, Modelo formativo, PLS-SEM, Prácticas de Alto Rendimiento, HIWP

Códigos JEL: O15, L25

\section{Introducción}

Una de las cuestiones más importantes en el marco de las investigaciones en Sistema de Gestión de Recursos Humanos, y más concretamente en las relacionadas con el uso de Programas de Alto Rendimiento (HIWP - High involvement work programs en inglés), es entender cómo estos afectan a los resultados de la empresa (Becker \& Huselid, 2006; Benson, Young \& Lawler III, 2006; Bowen \& Ostroff, 2004; Huselid \& Becker, 1996) y conseguir descifrar lo que se ha identificado como "The black box" (Jiang, Takeuchi, \& Lepak, 2013)

La investigación alrededor de este campo es elevada y ha permitido que, a través de varios metaanálisis, se hayan analizado los resultados de investigaciones previas. Destacando, en este sentido, los trabajos realizados por Combs, Liu, Hall y Ketchen (2006) que evalúa los resultados de 92 investigaciones sobre la influencia de la aplicación de estos programas en la "performance" empresarial, Subramony (2009) que evalúa la relación entre tres paquetes de programas de gestión de recursos humanos que configuran el modelo AMO (Ability, Motivation, Opportunity) y el rendimiento empresarial en 65 artículos, y Jiang, Lepak, Hu y Baer (2012), que analiza de forma más compleja y detallada las relaciones a diferentes niveles entre los ítems y los constructos que explican la relación entre los programas del modelo AMO y la performance empresarial en 116 artículos previos. Estos metaanálisis nos confirman que los HIWP afectan positivamente a la performance empresarial. 
Aunque también hay que señalar que algunos investigadores han identificado resultados contradictorios, por ejemplo, Cappelli y Neumark (2001) y Wright, Gardner, Moynihan y Allen (2005) argumentan que el uso de las prácticas de alta implicación puede aumentar la productividad, pero también aumentar los costes de la mano de obra, pues requieren más personal. Boselie, Dietz y Boon (2005) apunta la posibilidad de que las organizaciones con un alto rendimiento en un momento determinado, tal vez invierten sus recursos adicionales en implantar programas de recursos humanos que conducen después a un mejor desempeño, abriendo la puerta a la existencia de una posible causalidad inversa, que únicamente se podría descartar realizando investigaciones longitudinales, o cuasi-longitudinales.

A pesar de la existencia de estos resultados puntuales contradictorios, son mayoría los investigadores que confirman, a través de numerosos estudios de campo, la existencia de una relación positiva entre el uso de los HIWP y la mejora en los resultados, ya sean resultados operativos, financieros o de recursos humanos (Conci, 2012).

Sin embargo, a nivel metodológico nos encontramos con algunos aspectos que plantean incertidumbres sobre los resultados obtenidos en estos estudios de campo que se plantean identificar las relaciones que se dan en esta "Black box". En primer lugar, debemos mencionar el hecho de que los cuestionarios utilizadas por los investigadores para analizar estas relaciones entre HIWP y la "performance" empresarial son muy dispares, dado que se suelen crear cuestionarios específicos para cada investigación, y en raras ocasiones se reutilizan los diseñados por otros investigadores, lo que significa que no disponemos de un modelo de medida consistente y ampliamente difundido a nivel de la comunidad científica (MarinGarcia, 2013).

Además, y más importante, no es habitual encontrar la validación de los modelos de medida utilizados, pues casi todos los trabajos se centran en probar los modelos de estructura, y aún es más raro encontrar estudios que validen los modelos de medida en muestras distintas (Marin-Garcia \& Conci, 2010, 2012).

Y, por último, en las escasas investigaciones en las que se ha planteado la validación del modelo de medida, lo cierto es que, en cuanto a los HIWP, los resultados no son concluyentes (Marin-Garcia \& Conci, 2009, 2012, 2013).

Estas notas discordantes a nivel metodológico, que están todavía pendientes de resolver, han contribuido a que los HIWP no sean todavía un cuerpo establecido de teoría, sino un área de efervescencia teórica (Boxall, 2012). 
En este marco, y teniendo en cuenta que los intentos por validar el modelo de medida de los HIWP utilizando modelos reflectivos entre ítems y constructos (Marin-Garcia \& Conci, 2013), no han dado buenos resultados, con este trabajo nos planteamos:

- Comprobar el modelo de medida de los HIWP del cuestionario de Lawler (1986) como modelo formativo (compositemode B).

- Analizar la capacidad predictiva del modelo planteado.

Para nuestra investigación tomamos como referencia el cuestionario diseñado por Lawler (1986), dado que es uno de los escasos modelos que ha sido reutilizado por otros investigadores para evaluar el uso de los HIWP. El cuestionario que plantea Lawler da lugar a un modelo de constructos en los que las relaciones están sin especificar, por lo que podrían considerarse como reflectivos o como formativos, pero a pesar de esta posible doble naturaleza, y aunque en pocas investigaciones se ha hecho explícita esta relación, todos los estudios consultados han optado por considerar modelos reflectivos, dato que se desprende del tipo de análisis estadístico que aplican (Marin-Garcia \& Conci, 2013).

En la Figura 1 se muestra el modelo a comprobar, que está adaptado del cuestionario de Lawler (1986) y tiene en cuenta los resultados de investigaciones previas (Marin-Garcia \& Conci, 2013). Las variables (constructos), indicadores y relaciones que lo conforman son:

- "Comunicación", "Formación", "Remuneración" y "Participación". Se trata de constructos exógenos de primer orden y emergentes, es decir, están compuestos por indicadores formativos, lo que implica, como se describe más adelante, que los constructos son función de los indicadores que preceden al constructo.

- "HIWP". Se trata de un constructo de segundo orden formativo, que completa el modelo de medida de las HIWP

- "Resultados percibidos". Es un constructo endógeno de primer orden y reflectivo, atendiendo a los resultados de investigaciones previas (Conci, 2012) 


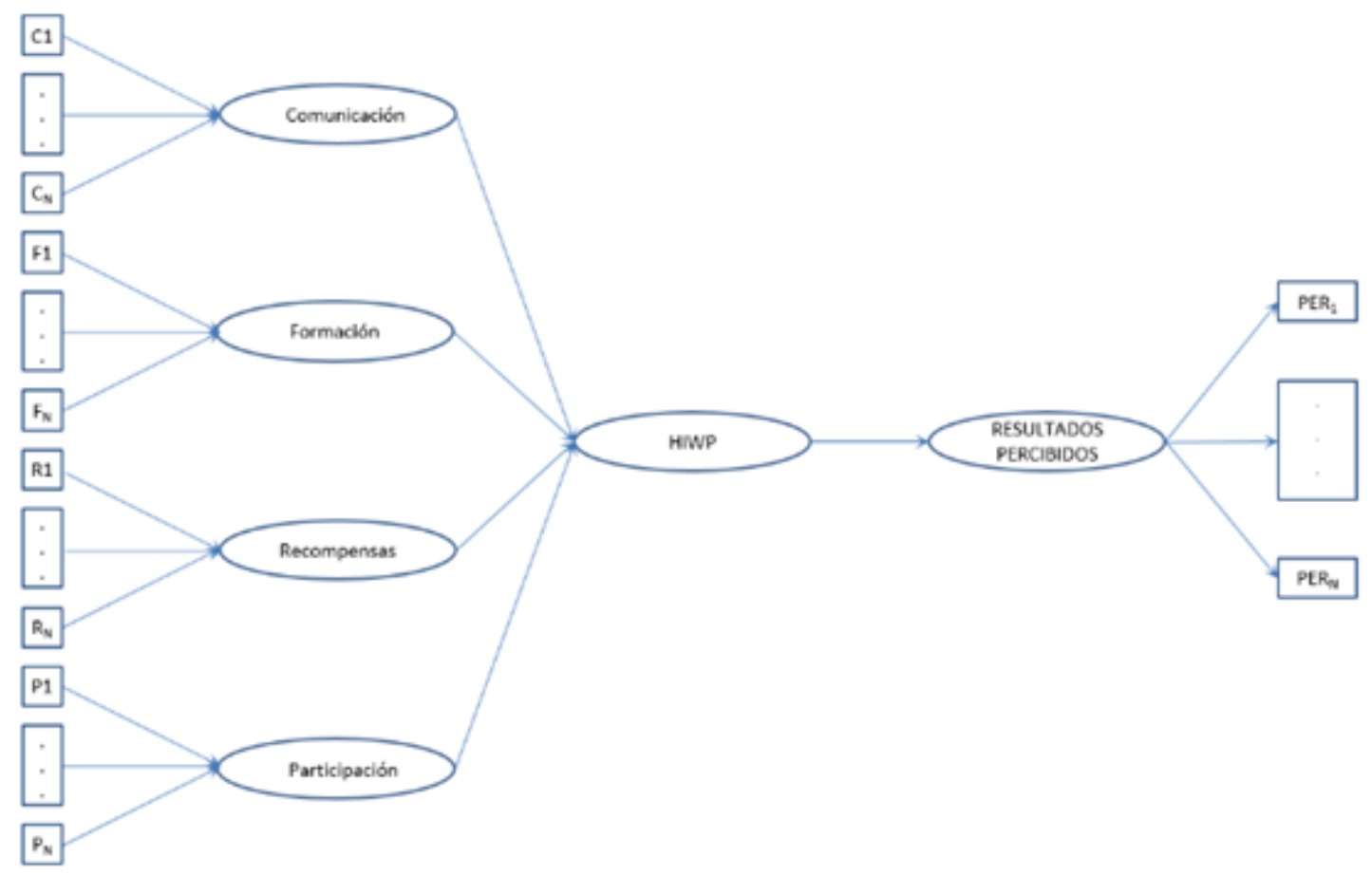

Figura 1. El modelo de partida a comprobar. A partir de (Lawler III, 1986; Marin-Garcia \& Conci, 2013)

Por lo tanto, partiendo del cuerpo teórico existente, que afirma que existe una relación positiva entre los HIWP y la performance (Arthur, 1994; Camps \& Luna-Arocas, 2009; Ericksen, 2007; Guerrero \& Barraud-Didier, 2004; Guthrie, Spell \& Nyamori, 2002; Huselid, 1995; Wright et al., 2005; Zheng, Morrison \& O'Neill, 2006), al comprobar el modelo desarrollado por Lawler (1986) para medir los HIWP, analizaremos si existe una relación positiva. Si por el contrario, cuando vinculemos los HIWP y la performance, no encontramos la relación positiva que se ha establecido a nivel teórico, tendremos que concluir que el modelo de medida que utilizamos no es correcto.

De este modo, si conseguimos validar el modelo, dispondremos de una herramienta para medir los HIWP, que no presentará ninguna duda a nivel metodológico, y que por lo tanto podrá usarse de forma válida y fiable.

Respecto a la medida de la performance empresarial, aunque el modelo planteado ha sido validado en estudios previos, también abordaremos su validación en este trabajo, con el objetivo de cumplir con todas las etapas que han propuesto Hair, Ringle y Sarstedt (2013) para garantizar la calidad mínima de los trabajos que utilizan la técnica PLS de análisis. 
Esta técnica de modelado de ecuaciones estructurales por mínimos cuadrados parciales (PLS- SEM), no nos permite establecer relaciones de causalidad (no es confirmatoria), pero es más adecuada para realizar predicciones, y además nos brinda la posibilidad de evaluar la relación entre los ítems y los constructos de primer orden, así como estos con los constructos de segundo orden, de forma tanto reflectiva como formativa. El software utilizado ha sido SmartPLS (Ringle, Wende \& Becker, 2015).

En cuanto a los datos, vamos a utilizar los resultados de trabajos de campo realizados en Estados Unidos en los años 1996 y 1999 (Lawler III, Mohrman, \& Benson, 2001; Lawler III, Mohrman, \& Ledford, 1998) y de España en 1997 (Marin-Garcia, Bonavía Martín, \& Miralles Insa, 2008).

\subsection{El modelo de Lawler. La “black box" entre HIWP y la performance}

Lawler y colaboradores (Lawler III, 1986), miembros del CEO (Center for Effective Organizations) de la Universidad de California del Sur, diseñaron un cuestionario para analizar el uso de determinadas prácticas consideradas como de Alta implicación/Rendimiento, y su repercusión en determinados indicadores de resultados.

Este cuestionario ha sido utilizado por el "Center for Effective Organizations" desde el año 1987 para realizar un total de 6 encuestas hasta el año 2002, con una periodicidad trianual, dirigidas a las empresas de la lista Fortune 1000 de EEUU. Si bien estas encuestas no se pueden considerar propiamente un estudio longitudinal, dado que la lista Fortune va cambiando su composición a lo largo de los años, las encuestas indican un gran aumento en el número de empresas que utilizan los HIWP, así como el porcentaje de empleados afectados. Por ejemplo, el número de empresas en las que por lo menos el 20\% de los empleados utilizan equipos autogestionados aumentó del 8\% en 1987 a 32\% en 1996, y aunque los resultados de la última encuesta llevada a cabo en el año 2002 muestran que la adopción de programas de participación de los empleados sufría una ligera desaceleración (Lawler III et al., 2001), el porcentaje de las grandes empresas que utilizan HIWP, así como la cantidad de empleados afectados ha crecido de forma considerable a lo largo de la serie evaluada.

La importancia del cuestionario de Lawler (1986) radica en que su uso se ha extendido más allá de las investigaciones abordadas por Lawler desde el CEO, y, con algunas adaptaciones, ha sido utilizado por otros investigadores de este campo (Benson et al., 2006; Coye \& Belohlav, 1995; Drehmer, Belohlav \& Coye, 2000; Guerrero \& Barraud-Didier, 2004; Lawler, 2005; Marin-Garcia et al., 2008; Yu, Finegold, Lawler \& Cochran, 2000), de forma que si conseguimos validar el modelo de medida que plantea 
Lawler, contribuiremos a reforzar y confirmar los resultados obtenidos por los investigadores que lo han utilizado en el pasado.

Lawler y colaboradores plantean en su modelo, en lo que se refiere a los HIWP, la existencia de 4 constructos, "comunicación", "formación", "remuneración" y "participación", y cada uno de estos constructos se mide a través de una serie de indicadores (ver Anexo 1).

\begin{tabular}{|l|l|}
\hline CONSTRUCTO & DEFINICIÓN \\
\hline $\begin{array}{l}\text { Comunicación/ } \\
\text { Communication }\end{array}$ & $\begin{array}{l}\text { Tipo de información que se comparte con los empleados para tomar decisiones relacionadas con la } \\
\text { mejora de su puesto de trabajo o con la mejora de la empresa }\end{array}$ \\
\hline $\begin{array}{l}\text { Formación/ } \\
\text { Training }\end{array}$ & $\begin{array}{l}\text { Formación sistemática y formal ofrecida a los empleados en los últimos tres años, y en diferentes } \\
\text { habilidades para aumentar su compromiso y para el desarrollo de sistemas de gestión global de la } \\
\text { calidad o similares }\end{array}$ \\
\hline $\begin{array}{l}\text { Recompensas/ } \\
\text { Rewards }\end{array}$ & Uso de programas o sistemas de recompensas que tienden a apoyar la implicación del personal \\
\hline $\begin{array}{l}\text { Participación/ } \\
\text { Empowerment }\end{array}$ & $\begin{array}{l}\text { Programas o cambios organizativos que permiten desplazar la toma de decisiones o el poder hacia } \\
\text { los trabajadores }\end{array}$ \\
\hline
\end{tabular}

Tabla 1. Constructos HIWP. Fuente (Lawler III et al., 1998; Lawler III et al., 2001)

En cada indicador se pregunta a los encuestados el grado en que cada uno de los programas de alta implicación se utilizan en su empresa, usando una escala de 1 a 7 con las siguientes equivalencias: 1 ( $0 \%$ de los empleados participa en estas actividades o programas), 2 (1\%-20\%), 3 (21\%-40\%), 4 (41\%-60\%), 5 (61\%-80\%), 6 (81\%-99\%), 7 (100\% de los empleados).

Por otro lado, el constructo "performance" empresarial se mide con indicadores subjetivos a través de la pregunta “CCómo valora el impacto positivo o negativo, si existe, que tienen los esfuerzos para lograr la implicación del trabajador en los siguientes indicadores del rendimiento de la empresa?”. Para responder a esta pregunta, Lawler propone varios ítems, relacionados con los constructos "Desempeño y servicio", "Resultados de recursos humanos" y "Resultados de la organización", con la siguiente escala de respuesta: Muy negativo (1), negativo (2), neutral (3), positivo (4) muy positivo (5).

Sobre la relación entre los ítems y los constructos del modelo, ni Lawler y sus colaboradores del CEO, ni en general los investigadores que han utilizado su cuestionario explicitan estas relaciones. Por lo tanto no queda claro si las consideran como reflectivas o como formativas. Sin embargo, por la sistemática y los estadísticos utilizados en el análisis de los datos, se deduce que han tratado como reflectiva la relación de ítems/indicadores con los constructos, y también la relación de los constructos con el factor de segundo orden, cuando este se plantea. 
Puesto que la validación del modelo de medida es un paso previo para probar cualquier modelo de estructura (Hair, Ringle et al., 2013) otros investigadores ya se han planteado la cuestión que nosotros abordamos con este trabajo, sin embargo, estos trabajos previos han detectado problemas, tanto para la validación del modelo de medida de los constructos exógenos (Comunicación, formación, remuneración y participación), como para los constructos endógenos HIWP, y performace, por lo que proponen variantes al modelo inicial planteado por Lawler, tal y como se describe a continuación.

Respecto a los Resultados previos sobre la validación de los constructos exógenos, en general, en las investigaciones en las que se aportan datos de las alfas de Cronbach, se obtiene que las de los constructos comunicación y formación son buenas, pero las de participación y remuneración no llegan al nivel de 0.70 en los pocos casos donde se ha informado de su valor (Marin-Garcia \& Conci, 2013).

En otras investigaciones, en las que las prácticas de alta implicación se han considerado todas juntas en un solo constructo, las alfas de Cronbach tienen valores alrededor del umbral (0.7), tanto por encima como ligeramente por debajo: 0.78 (Datta, Guthrie \& Wright, 2005); 0.69 (Guthrie, 2001); 0.67 (Huselid, 1995).

Más consistente, en cuanto a la validación del modelo de medida de los HIWP, es el trabajo de Yu et al. (2000), que utiliza también el cuestionario de Lawler, y analiza las relaciones entre ítems y constructos de forma reflectiva. En este trabajo, realizado con empresas asiáticas, los resultados obtenidos confirman que el modelo de medida no se ajusta a los datos recogidos en empresas de Estados Unidos, concluyendo que en el entorno asiático difícilmente se pueden considerar los constructos de participación y remuneración como unidimensionales y, mucho menos, considerar un factor latente de segundo orden que represente los HIWP. Sin embargo, tanto la comunicación como la formación sí que ajustan bien como constructos unidimensionales (las cargas factoriales de los ítems de cada dimensión son significativas y, casi todas ellas, superiores a 0.60).

Siguiendo con el análisis de los trabajos que abordan la validación del modelo de medida de los HIWP, en el trabajo realizado por Marín-García (2013) se abordó un análisis confirmatorio utilizando un Modelo de Ecuaciones Estructurales Basado en Covarianzas (CB-SEM), para evaluar los cuatro constructos que plantea Lawler (Comunicación, Formación, Remuneración y Participación), y determinar si la agrupación de ítems en estos cuatro constructos se ajustaba a tres series de datos de campo independientes (diferentes países y diferentes años), que son las mismas que vamos a utilizar en nuestra investigación. Para el análisis se utilizó el programa EQS, con datos de España (1997) y Estados Unidos (1996 y 1999), y el objetivo planteado era evaluar si la agrupación de ítems en las categorías 
propuestas en los modelos teóricos se ajustaba al conjunto de datos obtenidos, según un modelo reflectivo.

En este análisis sólo los constructos "Formación” y "Comunicación” superaron claramente el test de la validez convergente, sin embargo, sólo se pudo validar parcialmente el modelo de medida reflectivo de las escalas de participación y remuneración.

Por otro lado, respecto a los resultados de estudios previos sobre la validación del modelo de medida del constructo "performance", el trabajo realizado por Conci (2012), se planteaba validar el modelo de medida de la escala de resultados, partiendo de los datos obtenidos en empresas españolas (MarinGarcia et al., 2008), utilizando una adaptación del modelo de Lawler et al. (1991).

En el proceso de análisis utilizado se utilizó la técnica EQS, partiendo de una relación reflectiva entre los indicadores y los constructos de performance.

En un primer intento de validación del modelo planteado por Lawler, con la existencia de 3 constructos diferentes de performance (Desempeño y servicio; Resultados de recursos humanos; Resultados de la organización) los estadísticos calculados no presentaron un buen ajuste, por lo que se analizó también un modelo que presentaba todos los ítems en un solo constructo, y tampoco en este caso los estadísticos de bondad de ajuste superaron los límites recomendados. Finalmente, y tras realizar varios ajustes intermedios, los análisis factoriales confirmatorios de los datos de 98 empresas españolas, permitieron a Conci (2012) validar un modelo que presentaba unos estadísticos de validez convergente muy buenos, pero eliminando los ítems cuya carga factorial estandarizad era baja, por lo que se plantea que los ítems que forman parte del constructo "Performance" son los que se muestran en la Tabla 2.

\begin{tabular}{|l|l|}
\hline $\begin{array}{l}\text { Resultados } \\
\text { Percibidos }\end{array}$ & Productividad, Calidad, Atención al cliente, Satisfacción de los trabajadores, Competitividad \\
\hline
\end{tabular}

Tabla 2. Indicadores que forman parte del constructo "Resultados percibidos". Fuente (Conci, 2012) 


\subsection{Acerca de los modelos formativos}

En nuestro análisis partimos de la base de que los constructos en sí mismos no son formativos o reflectivos, sino que la clave está en cómo estos se han concebido, sus relaciones y cómo se miden (Hair, Hult, Ringle \& Sarstedt, 2013).

Teniendo esto en cuenta, y dado que los estudios previos disponibles que han intentado validar el modelo con relaciones reflectivas no han dado resultado, tal y como se ha apuntado en el apartado anterior, hemos analizado en qué medida el modelo se puede analizar cómo formativo.

Para ello, hemos aplicado el planteamiento que proponen Jarvis, Mackenzie y Podsakoff (2003) para identificar un modelo formativo: "Asumiendo que todas las medidas de un constructo están codificadas en la misma dirección, ¿el incremento de uno de los indicadores en una dirección implica que el resto debe cambiar de forma similar? Si la respuesta es afirmativa, nos encontramos con indicadores reflectivos. Si la respuesta es negativa, nos enfrentamos a indicadores formativos". Analizando cómo se han operacionalizado los cuatro constructos que conforman nuestro modelo de medida de los HIWP, la respuesta a esta pregunta es negativa, por lo en principio esto apunta a que nos encontramos con un modelo formativo.

Para confirmar que realmente nos encontramos con un modelo formativo, se ha evaluado el cumplimiento de las 5 condiciones teóricas propuestas por (Hair, Hult et al., 2013):

- prioridad causal de los indicadores hacia el constructo (el constructo formativo es consecuencia de la combinación de sus indicadores);

- El constructo es una combinación de los indicadores

- Los indicadores representan las causas del constructo

- variaciones en sus indicadores provocan cambios en el constructo, pero no a la inversa, y

- $\quad$ sus indicadores no son intercambiables.

Respecto al dominio conceptual de cada uno de los constructos y la cantidad de indicadores evaluados para inferirlos, son los establecidos en el cuestionario planteado por Lawler (1986), y por lo tanto no han sido objeto de análisis. 


\section{Metodología}

Teniendo en cuenta que la base de nuestra argumentación es probar la existencia de relaciones formativas entre los indicadores (ítems) y los constructos de los HIWP, vamos a utilizar una técnica de modelado de ecuaciones estructurales por mínimos cuadrados parciales (PLS- SEM) de amplia utilización en el ámbito de las ciencias sociales en los últimos años (Hair, Hult et al., 2013).

Los datos de EEUU provienen de la lista Fortune 1000, donde están representadas las empresas más grandes del país, tanto industriales como de servicios, y se utilizarán los datos de las encuestas de los años 1996 y 1999. Los datos de España se tomaron en 1997 y provienen de una muestra al azar de 861 empresas industriales contenidas en la lista de Fomento de la Producción de las 2500 mayores empresas (1259 eran establecimientos industriales).

En el caso concreto de los datos de EEUU se han elegido los datos de los años 1996 y 1999, con objeto de que el conjunto de datos final, incluyendo a España 1997, estuviera en un periodo de tiempo cercano.

En la encuesta de 1999 de EEUU se recibieron 137 respuestas (15\% de tasa de respuesta), aproximadamente la mitad de las respuestas eran de empresas de producción y el resto empresas de servicios. El 44\% de las respuestas provenía del director de recursos humanos y el $66 \%$ restante de otros directivos de alto nivel. En la encuesta de 1996 de EEUU se recibieron 201 contestaciones (22\% de tasa de respuesta), aproximadamente la mitad de las empresas eran de producción y las otras de servicios. El 45\% de las respuestas provenía de los directores de recursos humanos y el 65\% restante de otros directivos de alto nivel. Los datos de España se tomaron en 1997 y se recibieron 101 respuestas (12\% tasa de respuesta). Todas ellas empresas industriales. El 63\% de las respuestas provenía del director de recursos humanos y el 37\% restante de otros directivos de alto nivel.

Aunque el cuestionario original de Lawler es más amplio, en nuestro análisis sólo hemos considerado los datos de aquellos indicadores que están presentes en las 3 series de datos que utilizamos como datos de partida, lo que nos deja un total de 30 indicadores relacionados con los constructos de prácticas de alta implicación (ver Anexo 1). Los 30 ítems sirven para medir los cuatro constructos propuestos en este estudio: comunicación (5 ítems), formación ( 7 ítems), remuneración (9 ítems) y participación (9 ítems), que originalmente se midieron usando una escala de 1 a 7 con las siguientes equivalencias: $1(0 \%$ de los empleados participa en estas actividades o programas), 2 (1\%-20\%), 3 (21\%-40\%), 4 (41\%-60\%), 5 (61\%-80\%), 6 (81\%-99\%), 7 (100\% de los empleados). 
Por otro lado, el constructo "performance" empresarial se mide con indicadores subjetivos a través de la pregunta “ ¿Cómo valora el impacto positivo o negativo, si existe, que tienen los esfuerzos para lograr la implicación del trabajador en los siguientes indicadores del rendimiento de la empresa?". Aunque originalmente Lawler propone 11 ítems, 4 de ellos relacionados con "Desempeño y servicio", 4 relacionados con "Resultados de recursos humanos" y 3 relacionados con "Resultados de la organización", y para cada ítem se utiliza una escala de 1 a 5 con las siguientes equivalencias: 1 (muy negativo), 2 (negativo), 3 (neutral), 4 (positivo) y 5 (muy positivo), en nuestro modelo, que parte de la validación realizada por Conci (2012), sólo se utilizan los 10 indicadores que se contemplaron en el cuestionario español (ver Anexo 1).

Para poder evaluar los datos usando PLS hemos convertido las escalas de HIWP, que están en formato de intervalo (1 a 7), al valor intermedio del intervalo de \% de empleados que participa en estas actividades o programas (ver Tabla 3).

\begin{tabular}{|c|c|r|}
\hline $\begin{array}{c}\text { Dato original (escala } \\
\text { intervalo) }\end{array}$ & $\begin{array}{c}\text { \% de empleados que participa en estas } \\
\text { actividades o programas }\end{array}$ & $\begin{array}{c}\text { Dato convertido (valor medio } \\
\text { de cada intervalo) }\end{array}$ \\
\hline 1 & $0 \%$ de los empleados participa en estas \\
actividades o programas & 0 \\
\hline 2 & $1 \%-20 \%$ & 30 \\
\hline 3 & $21 \%-40 \%$ & 50 \\
\hline 4 & $41 \%-60 \%$ & 70 \\
\hline 5 & $61 \%-80 \%$ & 90 \\
\hline 6 & $81 \%-99 \%$ & 100 \\
\hline 7 & $100 \%$ de los empleados & \\
\hline
\end{tabular}

Tabla 3. Transformación de los valores de los ítems de HIWP

El constructo "performance" no se reescala porque no representa un intervalo.

En cuanto a la metodología de comprobación se aplica el protocolo sugerido por Hair, Hult et al. (2013), tanto para la validación del modelo de medida como para el modelo de estructura:

- Para la comprobación del modelo de medida de los HIWP se abordarán las 3 etapas propuestas: evaluación de la validez convergente usando un análisis redundante, análisis de la Multicolinealidad de los indicadores, y por último evaluación de la significación y relevancia de los indicadores formativos. La comprobación se realizará de forma independiente para cada una de las 3 muestras (España-1997, EEUU-1996 y EEUU-1999), excepto para la primera etapa 
(evaluación de la validez convergente), dado que sólo disponemos de datos para evaluar la muestra de EEUU-1996.

- También se comprueba la validez del modelo de medida reflectivo del constructo "performance", teniendo en cuenta los resultados de investigaciones previas que validaron el modelo de medida como reflectivo en la muestra de España-1997 (Conci, 2012).

- Una vez comprobado el modelo de medida, analizaremos el modelo de estructura, siguiendo las 5 etapas que marca Hair, Hult et al. (2013): evaluar colinealidad; evaluar la significación y relevancia de los relaciones del modelo de estructura (path coeficientes); evaluar el coeficiente de determinación $\left(\mathrm{R}^{2}\right)$; evaluar el effectsize $\left(\mathrm{f}^{2}\right)$; y por último evaluar la relevancia predictiva $\mathrm{Q}^{2}$ y el $\mathrm{q}^{2}$ effectsizes. De nuevo esta comprobación la realizaremos de forma independiente para cada una de las tres muestras a analizar.

La definición del constructo de segundo orden "HIWP" tiene su origen en la teoría que define los HIWP como conjunto de programas que actúan sinérgicamente y mejoran la eficiencia organizativa al crear condiciones laborales que incrementan la satisfacción del trabajador, le incentivan a vincularse con la organización y a desempeñar mejor sus tareas (Huselid, 1995). Además, teniendo en cuenta lo indicado por Barroso Castro, Cepeda Carrión y Roldán Salgueiro (2007), este constructo se ha definido con relaciones formativas dado que es una combinación aditiva de las 4 dimensiones (Comunicación, formación, remuneración y participación), que representan facetas heterogéneas que realizan una contribución única al constructo. Respecto a la operacionalización de este constructo, entre las dos técnicas que generalmente se usan para estimar los parámetros de los constructos de segundo orden en PLS (1) la repetición de indicadores y (2) el método en dos etapas (Ringle et al., 2015), en nuestro estudio hemos optado por utilizar el método de repetición de indicadores, con relaciones formativas, dado que nos permite estimar todas las relaciones entre los constructos simultáneamente (Hair, Hult et al., 2013).

Se describe a continuación, de forma breve, la metodología que propone Hair, Hult et al. (2013) para la comprobación del modelo de medida y la comprobación del modelo de estructura. 


\subsection{Modelos Formativos. Comprobación del modelo de medida}

\subsubsection{Etapa 1- Evaluación de la validez convergente}

La validez convergente representa la medida en la que un indicador se relaciona con otros indicadores del mismo constructo. Cuando se comprueban modelos de medida formativos tenemos que evaluar en qué medida el constructo formativo esta correlacionado con una medida reflectiva del mismo constructo. Este proceso se conoce también como análisis redundante, ya que evaluamos que los indicadores están incluidos en el constructo formativo y también en el reflectivo. El valor del pathcoefficient que une los dos constructos es indicativo de la validez del conjunto de indicadores formativos para evaluar el constructo de interés. Se plantea como objetivo un valor de $\mathrm{r}^{2}$ de 0.81 o al menos 0.64 . Si el modelo muestra falta de validez convergente implica que los indicadores que forman parte del modelo formativo no contribuyen con un nivel suficiente a su cometido previsto, por lo que los constructos deben conceptualmente reformulados mediante el intercambio y/o la adición de Indicadores.

En nuestro caso, para comprobar la validez convergente se ha utilizado una cuestión que se planteó en el cuestionario de EEUU-1996, y que representa a nivel global el uso de los HIWP:

"Aproximadamente qué porcentaje de los empleados de la organización están en unidades en las que se aplica alguna de las siguientes pautas de conducta? Le rogamos distribuya el $100 \%$ al responder las cuestiones 1 a 5 .

- Ninguno. No existe una participación significativa de los empleados en esta unidad de la empresa

- Equipos de Mejora. La Participación de los empleados se centra en los grupos especiales que se encargan de recomendar mejoras a la gestión. Estos grupos pueden ser grupos de participación, círculos de calidad ...

- Participación en el trabajo. La Participación de los empleados se centra en métodos de trabajo altamente motivadores, tales como equipos autogestionados, entrenamiento centrado en las habilidades específicas de trabajo y / o el funcionamiento del equipo ...

- Participación en la gestión. Los empleados participan en gran medida en la gestión de la empresa. Equipos de mejora y enfoques de participación de trabajo pueden ser utilizados como parte de esta estrategia ... 
- Otra forma de participación. Implicación de los trabajadores no descritos por 2, 3 o 4." (Lawler III, 1986)

Como se puede ver, esta pregunta estaba formulada como una variable de escala, pero se ha convertido en una variable monoitem, realizando una media ponderada, tras asignar a cada una de las opciones planteadas en el cuestionario los pesos indicados en la Tabla 4.

\begin{tabular}{|l|r|}
\hline \multicolumn{1}{|c|}{ Cuestión } & \multicolumn{1}{|c|}{$\begin{array}{c}\text { Peso } \\
\text { asignado }\end{array}$} \\
\hline $\begin{array}{l}\text { 1. None. No significant employee involvement exists in these parts of the corporation } \\
\text { 2. Improvement Teams. Employee involvement focuses on special groups that are } \\
\text { responsible for recommending improvements to management. These groups may be } \\
\text { participation groups, quality circles... }\end{array}$ & 5 \\
\hline $\begin{array}{l}\text { 3. Job involvement. Employee involvement focuses on creating work designs that are highly } \\
\text { motivating, such as self-managing teams. Training focuses on job specific skills and/or team } \\
\text { functioning... }\end{array}$ & 7 \\
\hline $\begin{array}{l}\text { 4. Business involvement. Employees are involved heavily in the management of the business. } \\
\text { Improvement teams and job involvement approaches may be used as part of this strategy... }\end{array}$ & 10 \\
\hline 5. Other form of involvement. Employee involvement approaches not described by 2,3 or 4. & 3 \\
\hline
\end{tabular}

Tabla 4. Transformación de las preguntas sobre el uso global de HIWP en una variable monoitemreflectiva

\subsubsection{Etapa 2- Evaluación de la multicolinealidad}

En un modelo formativo, en el que los indicadores no son intercambiables, no deben existir correlaciones elevadas entre los ítems que conforman cada constructo (Cepeda \& Roldán, 2004). De hecho, elevadas correlaciones entre indicadores nos darían problemas metodológicos y de interpretación de resultados, ya que dificultarían identificar el efecto que cada uno de ellos tiene sobre el concepto (Hair, Hult et al., 2013).

Para evaluar la multicolinealidad se analiza que el factor de inflación de la varianza (FIV), sea mayor que 0.2 y menor que 5 en cada uno de los indicadores que forman los diferentes constructos. Este valor lo proporciona directamente el SmartPLS en la versión 3.2.3. 


\subsubsection{Etapa 3- Evaluación de la significación y relevancia de los indicadores formativos}

Otro criterio importante para evaluar la contribución de un indicador formativo y su relevancia es el outerweight. El peso (outerweight) es el resultado de una regresión múltiple (Hair, Hult et al., 2013) en la que los constructos son la variable dependiente y los indicadores (ítems) son las variables independientes. Dado que el constructo en sí está formado por sus indicadores (ítems) formativos subyacentes, un análisis de regresión múltiple debería proporcionar un valor de $\mathrm{R}^{2}$ de 1.0 (sin varianza del error, $100 \%$ del constructo se explica por los indicadores). Debemos probar si los outerweight en los modelos formativos son significativamente diferentes de cero, por medio del procedimiento de bootstrapping (técnica no paramétrica de remuestreo).

Teniendo en cuenta que el peso (outerweight) máximo de los indicadores que conforman cada constructo es $1 /$ raíz(n), en la Tabla 5 se indican los valores máximos para cada constructo.

\begin{tabular}{|r|r|r|r|}
\hline COMUNICACIÓN (5) & FORMACIÓN (7) & REMUNERACIÓN (9) & PARTICIPACIÓN (9) \\
\hline 0.4472 & 0.3780 & 0.3333 & 0.3333 \\
\hline
\end{tabular}

Tabla 5. Outerweight máximo de cada constructo formativo

Para obtener el nivel de significación, se analiza el valor del estadístico $\mathrm{T}$ tras realizar un remuestreo (Bootstrapping). Este valor de T debe ser $>1.96$ (test de dos colas), si $\mathrm{p}<0.05$ y $>1.645$ para $\mathrm{p}<0.1$.

Para abordar el remuestreo (Bootstrapping), se ha aplicado la siguiente configuración:

- Los valores perdidos se reemplazan por la media

- Sin cambio de signo

- $\quad$ Muestras $=5,000$

- Nivel de significación $=0.05$

Cuando el peso (outerweight) de un indicador es significativo, hay soporte empírico para mantener el indicador. Cuando el peso de un indicador no es significativo, pero su carga (load) es relativamente alta $(>0.5)$, el indicador debe mantenerse. 
Si ambos, el peso y la carga no son significativos, no hay apoyo empírico para retener el indicador y debería ser retirado del modelo.

Una vez descrita de forma breve la metodología para comprobar los modelos de medida formativos, a continuación describimos la metodología para comprobar los modelos de medida reflectivos.

\subsection{Modelos reflectivos. Comprobación del modelo de medida}

\subsubsection{Etapa 1 - Consistencia interna}

Se evalúa la consistencia interna de los indicadores que componen cada constructo, esto es, la rigurosidad con la que los indicadores (ítems) están midiendo el mismo constructo (variable latente). En SmartPLS se evalúa que la carga (outerloading) de los indicadores es superior a 0.708 .

\subsubsection{Etapa 2 - Fiabilidad del indicador}

En esta etapa se trata de examinar las cargas o correlaciones simples de cada medida o indicador con su respectivo constructo. En este caso se evalúa que la fiabilidad compuesta (compositereliability) tras un proceso de remuestreo (Bootstrapping) tiene una carga mínima de 0.707 para aceptar que un indicador sea integrante de un constructo, porque esto significaría que la varianza compartida entre el constructo y sus indicadores es mayor que la varianza del error.

\subsubsection{Etapa 3 - Validez convergente}

El objetivo es evaluar si un conjunto de indicadores miden realmente el constructo. Para analizar este tipo de validez se utiliza la varianza extraída media (AVE). El criterio de aceptación consiste en que la varianza extraída media (AVE) de un constructo ha de ser mayor a 0.5 , significando esto que el constructo comparte más de la mitad de su varianza con sus indicadores. 


\subsubsection{Etapa 4 - Validez discriminante}

Con este criterio se comprueba que un constructo determinado es diferente de otros. Para llevar a cabo esta comprobación tiene que cumplirse que la varianza que un constructo comparta con sus indicadores sea mayor que la que pueda compartir con otros constructos incluidos en el modelo.

\subsubsection{Comprobación del modelo de estructura}

Una vez comprobado el modelo de medida de forma independiente para cada muestra (EEUU1996, EEUU1999 y España1997), se abordará el análisis del modelo de estructura para determinar la capacidad predictiva del modelo y las relaciones entre los constructos, analizando también cada una de las muestras por separado, evaluando qué cantidad de la varianza del constructo endógeno (performance) es explicada por los constructos que lo predicen, y en qué medida los constructos predictores contribuyen a la varianza explicada del constructos endógeno. Para ello evaluaremos dos índices básicos: $\mathrm{R}^{2}$ y los coeficientes path o pesos de regresión estandarizados.

El proceso de análisis del modelo de estructura, siguiendo las indicaciones de Hair, Hult et al. (2013), tiene 5 etapas: evaluar colinealidad; evaluar la significación y relevancia de los relaciones del modelo de estructura (coeficientes path); evaluar el coeficiente de determinación $\left(\mathrm{R}^{2}\right.$ ), evaluar el impacto (effectsizes) $\left(\mathrm{f}^{2}\right)$ y por último evaluar la relevancia predictiva $\left(\mathrm{Q}^{2}\right)$ y el $\mathrm{q}^{2}$ (effectsizes) de los constructos endógenos reflectivos.

\subsection{Evaluación del modelo de estructura}

\subsubsection{Paso 1 - Análisis de la colinealidad}

Para asegurar que no existe colinealidad entre los 4 constructos que forman el constructo de segundo orden HIWP, se realiza una regresión múltiple de los coeficientes path de los constructos precedentes: Comunicación, formación, remuneración y participación. La versión 3.2.3. de SmartPLS que hemos utilizado en nuestro trabajo nos aporta directamente el dato del FIV, que debe ser $<5$. 


\subsubsection{Paso 2 - Coeficientes path del modelo de estructura}

Antes de examinar los coeficientes path, que representan las relaciones que existen entre los constructos, hay que evaluar si son significativos.

Para ello se ejecuta la opción de remuestreo - Bootstrapping, con los siguientes parámetros:

- Los valores perdidos se reemplazan por la media

- Sin cambio de signo

- $\quad$ Muestras $=5,000$

- Nivel de significación $=0.05$

Y se analiza el valor del estadístico T, entre cada uno de los constructos, que debe ser $>1.96$ (test de dos colas) para $\mathrm{p}<0.05, \mathrm{y}>0.98$ (test de una cola) para $\mathrm{p}<0.05$.

Tras evaluar la significación, evaluamos los coeficientes path, que se deben interpretar de forma relativa entre ellos. Si un coeficiente path es mayor que otro, su efecto en el constructo es mayor, y representan el cambio estimado que se produce en el constructo endógeno, por una unidad de cambio en el constructo predictor. Es decir, nos aporta información sobre la importancia relativa de cada constructo predictor.

\subsubsection{Paso 3 - Coeficiente de determinación (valor $\mathbf{R}^{2}$ )}

El valor de $\mathrm{R}^{2}$, coeficiente de determinación, es el valor más usado para evaluar los modelos de estructura, dado que representa el valor predictivo que tienen los constructos precedentes de cada constructo. El coeficiente representa los efectos combinados de los constructos exógenos combinados en el constructo endógeno, y representa también la varianza explicada del constructo endógeno por los diferentes constructos exógenos que lo explican.

El valor de $\mathrm{R}^{2}$ va de 0 a 1 , y valores próximos a 1 indican mayor capacidad predictiva, aunque en el área de management $\mathrm{R}^{2}$ superiores a $10 \%$ se pueden considerar como valores a tener en cuenta a pesar de ser bajos. 


\subsubsection{Paso 4 - Medida del impacto (f²)}

El f ${ }^{2}$ (effectsize ) es una medida del impacto de un constructo predictor en el constructo endógeno, y nos aporta información valiosa sobre el cambio que se produce en el valor de $\mathrm{R}^{2}$ cuando se elimina un constructo. De forma que valores de $\mathrm{f}^{2}$ por debajo de 0.02 nos dicen que ese constructo no tiene apenas efecto, por encima de 0.02 hasta 0.15 , el efecto se puede considerar medio, y valores por encima de 0.35 nos indican que se trata de un constructo que claramente debe formar parte del modelo.

Para obtener el valor de $\mathrm{f}^{2}$, cuando en el modelo de estructura varios constructos contribuyen a formar un constructo endógeno, se vuelve a calcular el modelo eliminando, uno a uno, las constructos que contribuyen, y se calcula aplicando la siguiente fórmula:

$$
f^{2}=\frac{R_{\text {incluido }}^{2}-R_{\text {excluido }}^{2}}{1-R_{\text {incluido }}^{2}}
$$

Dado que en nuestro modelo de estructura sólo hay un constructo (HIWP) que predice nuestra variable dependiente (constructo "performance"), no se puede calcular el valor de $\mathrm{f}^{2}$.

\subsubsection{Paso 5 - Blindfolding y relevancia predictiva $Q^{2}$}

Para los constructos reflectivos, que tienen incidencia en el modelo predictivo, se debe evaluar la relevancia predictiva $Q^{2}$, para analizar en qué medida los constructos exógenos contribuyen a la varianza explicada de los constructos endógenos del modelo. Para ello, siguiendo las indicaciones de Hair, Hult at al. (2013), se aplica el "cross-validatedredundacyapproach", al ejecutar el Blindfolding para el constructo correspondiente.

Dado que en nuestro modelo el único constructo reflectivo es precisamente el constructo endógeno que queremos analizar, no procede realizar este último paso en la evaluación del modelo de estructura. 


\section{Resultados y discusión}

\subsection{Evaluación del tamaño muestral}

Antes de abordar el análisis se ha valorado si el tamaño muestral es suficiente para estimar el modelo propuesto con la técnica PLS-SEM, ya que la estabilidad de las estimaciones puede verse afectada por el tamaño de la muestra (Hair, Hult et al., 2013).

Además, para asegurar la adecuación del tamaño muestral hay que tener en cuenta el número de regresores que se han incluido en el modelo. Dadas las características de estimación de PLS, se aconseja como regla práctica para determinar el tamaño muestral requerido para poder aplicar esta técnica (Cepeda \& Roldán, 2004; Hair, Hult et al., 2013), multiplicar por 10 el número de indicadores que forman parte del constructo formativo de mayor complejidad (en nuestro caso 9); y el mayor número de constructos antecedentes que conducen a un constructo endógeno (en nuestro modelo 4), quedándonos con el resultado mayor.

De este cálculo se obtiene que, para nuestro modelo, el tamaña muestral debe ser superior a 90 . Teniendo en cuenta que los análisis se van a realizar de forma independiente para cada muestra de datos (EEUU1996, EEUU1999 y ESPAÑA1997), este dato no representa ningún problema, ya que en el caso de EEUU1996 contamos con 201 datos, para EEUU1999 tenemos 137 casos, y en ESPAÑA 1997 tenemos un total de 101 casos.

\subsection{Análisis descriptivo de los constructos}

Presentamos a continuación las tablas con los estadísticos descriptivos de las cuatro categorías de programas (constructos) que conforman el modelo de Lawler (1986): comunicación, formación, remuneración y participación en las tres muestras que evaluamos en nuestro estudio: España (1997), EEUU (1996) y EEUU (1999).

\begin{tabular}{|l|c|r|r|r|r|r|r|r|r|}
\cline { 2 - 10 } \multicolumn{1}{c|}{} & \multicolumn{4}{c|}{1996} & \multicolumn{3}{c|}{1999} & \multicolumn{3}{c|}{1997} \\
\cline { 2 - 10 } \multicolumn{1}{c|}{} & $\mathbf{N}$ & Media & Desv. típ. & N & Media & Desv. típ. & N & Media & \multicolumn{1}{c|}{ Desv. típ. } \\
\hline INFvar009 & 203 & 85.27 & 22.32 & 138 & 77.90 & 28.53 & 104 & 57.31 & 36.13 \\
\hline INFvar010 & 201 & 72.44 & 26.90 & 138 & 73.77 & 27.21 & 102 & 60.49 & 33.34 \\
\hline INFvar012 & 203 & 47.64 & 27.87 & 137 & 44.23 & 27.30 & 104 & 56.35 & 33.93 \\
\hline INFvar013 & 202 & 64.70 & 27.61 & 137 & 68.03 & 26.45 & 104 & 54.71 & 34.05 \\
\hline INFvar014 & 203 & 41.72 & 28.41 & 137 & 42.77 & 28.41 & 101 & 40.10 & 30.45 \\
\hline
\end{tabular}

Tabla 6. Indicadores de comunicación 
Las prácticas del constructo "comunicación" (Tabla 6) son las que presentan mayor grado de implantación en comparación a las demás categorías. En las tres muestras, son las que presentan mayor media y menor desviación típica, aunque la variabilidad en la muestra española es mayor que en las empresas EEUU. Los flujos de comunicación son ligeramente menores en España, salvo en lo relativo a nuevas tecnologías (INFvar012), donde la tendencia se invierte.

\begin{tabular}{|l|c|c|r|c|r|r|r|r|r|}
\cline { 2 - 10 } \multicolumn{1}{c|}{} & \multicolumn{4}{c|}{1996} & \multicolumn{3}{c|}{1999} & \multicolumn{3}{c|}{1997} \\
\cline { 2 - 10 } \multicolumn{1}{c|}{} & N & Media & Desv. típ. & N & Media & Desv. típ. & N & Media & Desv. típ. \\
\hline TRAvar015 & 202 & 36.58 & 24.61 & 135 & 31.11 & 22.22 & 104 & 34.13 & 27.58 \\
\hline TRAvar016 & 202 & 32.23 & 20.65 & 136 & 34.85 & 21.05 & 103 & 25.53 & 19.54 \\
\hline TRAvar017 & 201 & 28.66 & 20.73 & 136 & 30.88 & 23.21 & 104 & 21.35 & 17.63 \\
\hline TRAvar018 & 200 & 32.30 & 26.91 & 133 & 24.59 & 22.11 & 103 & 33.40 & 27.39 \\
\hline TRAvar019 & 201 & 40.80 & 24.58 & 136 & 38.82 & 24.68 & 103 & 38.16 & 30.96 \\
\hline TRAib6 & 202 & 58.66 & 25.66 & 136 & 59.04 & 26.88 & 104 & 56.25 & 34.05 \\
\hline TRAvar025 & 200 & 33.80 & 23.84 & 136 & 34.19 & 23.71 & 103 & 37.77 & 28.87 \\
\hline
\end{tabular}

Tabla 7. Indicadores de formación

Las prácticas de "Formación" (Tabla 7) presentan un grado de uso bastante parecido en las tres muestras. La más común es la formación necesaria para el propio trabajo (TRAib6) que alcanza a más de la mitad de los operarios en las tres muestras. El resto de programas tienen un despliegue moderado y afectan en torno al 30\%-40\% de los trabajadores.

\begin{tabular}{|l|c|r|r|r|r|r|r|r|r|}
\cline { 2 - 10 } \multicolumn{1}{c|}{} & \multicolumn{4}{c|}{1996} & \multicolumn{3}{c|}{1999} & \multicolumn{3}{c|}{1997} \\
\cline { 2 - 10 } \multicolumn{1}{c|}{} & N & Media & Desv. típ. & N & Media & Desv. típ. & N & Media & \multicolumn{1}{c|}{ Desv. típ. } \\
\hline REWvar029 & 201 & 14.28 & 20.73 & 135 & 13.70 & 18.15 & 94 & 36.38 & 38.91 \\
\hline REWvar030 & 198 & 42.68 & 42.51 & 134 & 38.81 & 39.96 & 89 & 18.09 & 33.64 \\
\hline REWvar032 & 198 & 14.14 & 26.14 & 136 & 17.13 & 27.35 & 89 & 16.97 & 31.57 \\
\hline REWvar033 & 198 & 35.10 & 31.73 & 137 & 38.39 & 30.59 & 93 & 30.22 & 33.69 \\
\hline REWid6 & 200 & 26.15 & 28.61 & 136 & 30.66 & 32.62 & 88 & 26.59 & 35.00 \\
\hline REWid7 & 198 & 58.69 & 34.95 & 136 & 65.59 & 35.54 & 90 & 23.67 & 36.12 \\
\hline REWvar034 & 200 & 51.80 & 45.02 & 136 & 53.09 & 44.01 & 88 & 6.36 & 20.41 \\
\hline REWvar035 & 201 & 53.48 & 44.28 & 136 & 58.31 & 43.76 & 90 & 12.67 & 25.61 \\
\hline REWvar020 & 193 & 15.70 & 30.71 & 131 & 14.35 & 29.20 & 84 & 36.79 & 45.90 \\
\hline
\end{tabular}

Tabla 8. Indicadores de remuneración

En "Remuneración" (Tabla 8), en línea con lo comentado en diversos trabajos (Conci, 2012; MarinGarcia et al., 2008) existen diferencias en los grados de uso de las diferentes herramientas. En Estados Unidos se usan con mayor intensidad que en España las prácticas de reparto de beneficios 
(REWvar030), recompensas no monetarias (REWid7), participación en el capital de la compañía (REWvar034) y remuneración flexible (REWvar035). Los complementos de grupo (REWid6) están a un nivel parecido, y la seguridad en el empleo (REWvar020) y el pago por habilidades (REWvar029) es mayor en España que en EEUU.

Por último, las prácticas de "Participación" (Tabla 9), en general, presentan un grado de despliegue bastante similar en España y EEUU, destacando el poco uso que hay en ambos países de programas de mini empresas (EMPvar041) y grupos semiautónomos (EMPvar042). Sin embargo hay diferencias en tres los nueve programas analizados. Las encuestas de opinión (EMPvar036) son claramente menos usadas en España que en EEUU. Por otra parte, los círculos de calidad (EMPvar038) y los comités de empresas (EMPvar040) afectan a más porcentaje de plantilla en España que en EEUU.

\begin{tabular}{|l|c|r|r|r|r|r|r|r|r|}
\cline { 2 - 10 } \multicolumn{1}{c|}{} & \multicolumn{4}{c|}{1996} & \multicolumn{2}{c|}{1999} & \multicolumn{3}{c|}{1997} \\
\cline { 2 - 11 } \multicolumn{1}{c|}{} & N & Media & Desv. típ. & N & Media & Desv. típ. & N & Media & Desv. típ. \\
\hline EMPvar027 & 202 & 39.75 & 35.25 & 137 & 40.88 & 35.51 & 96 & 35.63 & 41.16 \\
\hline EMPvar036 & 201 & 58.81 & 38.32 & 135 & 64.15 & 37.86 & 94 & 21.81 & 33.31 \\
\hline EMPvar037 & 201 & 28.41 & 23.84 & 135 & 23.48 & 24.41 & 91 & 27.81 & 30.32 \\
\hline EMPvar038 & 202 & 16.24 & 21.85 & 135 & 12.89 & 17.99 & 95 & 28.53 & 32.12 \\
\hline EMPvar039 & 202 & 37.38 & 28.78 & 136 & 32.87 & 27.75 & 92 & 31.85 & 32.41 \\
\hline EMPvar040 & 200 & 7.55 & 14.30 & 135 & 6.22 & 11.52 & 97 & 31.24 & 32.35 \\
\hline EMPvar041 & 200 & 14.80 & 20.62 & 132 & 14.62 & 22.76 & 83 & 7.35 & 22.74 \\
\hline EMPvar042 & 200 & 17.60 & 19.26 & 137 & 16.20 & 19.22 & 88 & 10.57 & 23.31 \\
\hline EMPp5q9 & 200 & 14.05 & 15.82 & 137 & 15.18 & 16.94 & 86 & 11.51 & 24.81 \\
\hline
\end{tabular}

Tabla 9. Indicadores de participación

\subsection{Resultados}

\subsubsection{HIWP. Evaluación del modelo de medida. Etapa 1 - Validez convergente}

Del análisis de la correlación del constructo formativo de segundo orden con una medida reflectiva del mismo constructo, que se conoce también como análisis redundante se obtiene que el coeficiente path que relaciona HIWP (formativo) con HIWP (reflectivo). Para la muestra de EEUU1996, este valor es de 0.65, que está ligeramente por encima del límite de aceptación: 0.64 (Hair, Hult et al., 2013) tal y como muestra la Figura 2. 


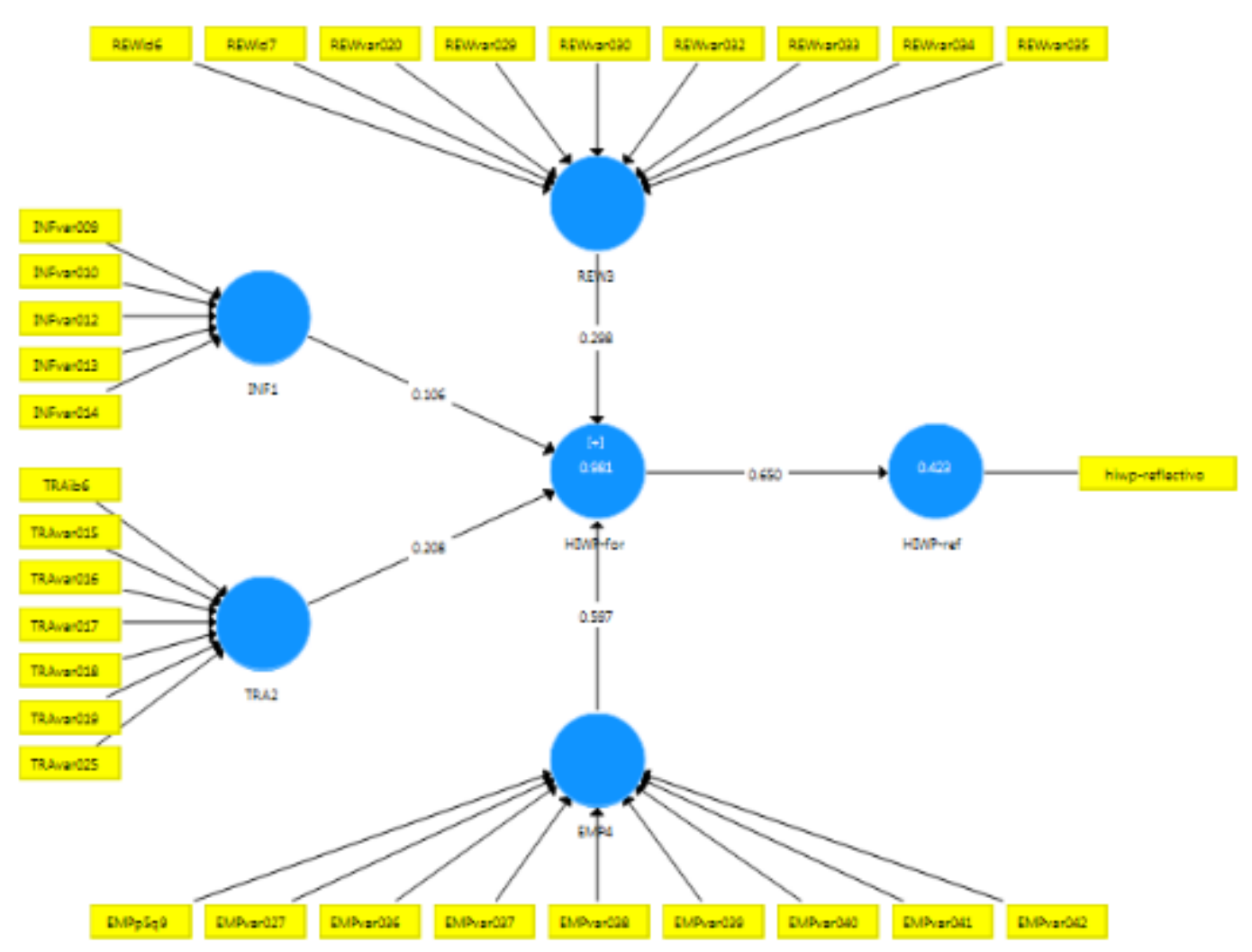

Figura 2. Modelo utilizado para evaluar la validez convergente del modelo de medida de HIWP formativo

\subsubsection{HIWP. Evaluación del modelo de medida. Etapa 2- Multicolinealidad}

La no colinealidad se evalúa a través del factor de inflación de la varianza (FIV) para los indicadores de cada constructo formativo en cada una de las muestras analizadas. Todos los valores se sitúan entre 1.053 y 3.172 que se encuentran muy por debajo de los umbrales mínimos (valores inferiores a 3.3 ó 5 (Hair, Hult et al., 2013), y por lo tanto podemos afirmar que no existe una alta correlación entre los indicadores o dimensiones de cada uno de los constructos formativos en ninguna de las tres muestras analizadas.

Además en el análisis de la Multicolinealidad entre cada grupo de indicadores, los resultados también muestran la ausencia de colinealidad entre los ítems que conforman el constructo de segundo orden en las muestras de EEUU 1996, EEUU1999 y ESPAÑA1997, por lo que podemos concluir que, en lo que respecta a la ausencia de colinealidad, los datos son aceptables. 


\subsubsection{HIWP. Evaluación del modelo de medida. Etapa 3 - Evaluación de la significación y} relevancia de los indicadores formativos

En esta etapa se pretende determinar en qué medida un indicador dado es diferente de los otros indicadores del constructo.

\begin{tabular}{|c|c|c|c|c|c|c|c|c|c|c|}
\hline & \multicolumn{2}{|c|}{ EEUU-96 } & \multicolumn{2}{|c|}{ EEUU-99 } & \multicolumn{2}{|c|}{ ESP-97 } & \multirow[b]{2}{*}{96} & \multirow[b]{2}{*}{99} & \multirow[b]{2}{*}{97} & \multirow[b]{2}{*}{ ¿Ok? } \\
\hline & $\begin{array}{c}\text { Weight } \\
\text { (T) }\end{array}$ & Loading & $\begin{array}{c}\text { Weight } \\
\text { (T) }\end{array}$ & Loading & $\begin{array}{l}\text { Weight } \\
\text { (T) }\end{array}$ & Loading & & & & \\
\hline EMPp5q9 -> 4EMP & 0.225 & 0.367 & 1.152 & 0.49 & 0.527 & 0.379 & NOK & NOK & NOK & no \\
\hline EMPvar027 -> 4EMP & 0.44 & 0.323 & 0.397 & 0.123 & 1.051 & 0.694 & NOK & NOK & OK & si \\
\hline EMPvar036 -> 4EMP & 2.889 & 0.617 & 0.91 & 0.395 & 0.801 & 0.608 & OK & NOK & OK & si \\
\hline EMPvar037 -> 4EMP & 2.238 & 0.72 & 1.206 & 0.702 & 0.968 & 0.724 & OK & OK & OK & si \\
\hline EMPvar038 -> 4EMP & 0.127 & 0.368 & 2.478 & 0.715 & 1.551 & 0.647 & NOK & OK & OK & si \\
\hline EMPvar039 -> 4EMP & 1.965 & 0.701 & 2.448 & 0.761 & 1.629 & 0.808 & OK & OK & OK & si \\
\hline EMPvar040 -> 4EMP & 0.743 & 0.367 & 1.606 & 0.433 & 0.39 & 0.432 & NOK & NOK & NOK & no \\
\hline EMPvar041 -> 4EMP & 1.277 & 0.455 & 0.63 & 0.504 & 0.067 & 0.306 & NOK & OK & NOK & si \\
\hline EMPvar042 -> 4EMP & 2.772 & 0.596 & 0.687 & 0.594 & 0.578 & 0.45 & OK & OK & NOK & si \\
\hline INFvar009 -> 1INF & 0.482 & 0.318 & 0.733 & 0.495 & 0.264 & 0.542 & NOK & NOK & OK & si \\
\hline INFvar010 -> 1INF & 2.531 & 0.781 & 2.032 & 0.763 & 2.251 & 0.891 & OK & OK & OK & si \\
\hline INFvar012 -> 1INF & 1.137 & 0.746 & 1.775 & 0.811 & 2.461 & 0.879 & OK & OK & OK & si \\
\hline INFvar013 -> 1INF & 0.771 & 0.663 & 0.409 & 0.654 & 0.158 & 0.593 & OK & $\mathrm{OK}$ & OK & si \\
\hline INFvar014 -> 1INF & 1.608 & 0.789 & 2.094 & 0.714 & 0.328 & 0.545 & OK & OK & OK & si \\
\hline REWid6 -> 3REW & 2.381 & 0.464 & 2.51 & 0.531 & 0.709 & 0.455 & OK & OK & NOK & si \\
\hline REWid7 -> 3REW & 1.731 & 0.505 & 1.394 & 0.378 & 1.532 & 0.71 & OK & NOK & OK & si \\
\hline REWvar020 -> 3REW & 3.045 & 0.513 & 0.279 & 0.111 & 1.312 & 0.511 & OK & NOK & OK & si \\
\hline REWvar029 -> 3REW & 4.311 & 0.64 & 4.127 & 0.646 & 0.765 & 0.2 & OK & OK & NOK & si \\
\hline REWvar030 -> 3REW & 1.525 & 0.337 & 1.959 & 0.398 & 0.281 & 0.216 & NOK & OK & NOK & si \\
\hline REWvar032 -> 3REW & 1.6 & 0.221 & 1.517 & 0.468 & 1.647 & 0.697 & NOK & NOK & OK & si \\
\hline REWvar033 -> 3REW & 0.298 & 0.19 & 0.046 & 0.31 & 1.08 & 0.585 & NOK & NOK & OK & si \\
\hline REWvar034 -> 3REW & 0.724 & 0.289 & 0.618 & 0.332 & 1.065 & 0.408 & NOK & NOK & NOK & no \\
\hline REWvar035 -> 3REW & 0.37 & 0.112 & 0.895 & 0.122 & 0.041 & 0.385 & NOK & NOK & NOK & no \\
\hline TRAib6 -> 2TRA & 2.25 & 0.725 & 0.577 & 0.274 & 2.026 & 0.92 & OK & NOK & OK & si \\
\hline TRAvar015 -> 2TRA & 1.393 & 0.701 & 0.07 & 0.673 & 0.315 & 0.781 & OK & $\mathrm{OK}$ & OK & si \\
\hline TRAvar016 -> 2TRA & 0.497 & 0.533 & 0.397 & 0.431 & 0.107 & 0.765 & OK & NOK & OK & si \\
\hline TRAvar017 -> 2TRA & 0.942 & 0.597 & 1.179 & 0.673 & 0.513 & 0.522 & OK & OK & OK & si \\
\hline TRAvar018 -> 2TRA & 1.781 & 0.608 & 3.042 & 0.855 & 0.152 & 0.733 & OK & OK & OK & si \\
\hline TRAvar019 -> 2TRA & 0.752 & 0.655 & 1.138 & 0.668 & 1.075 & 0.833 & OK & OK & OK & si \\
\hline TRAvar025 -> 2TRA & 2.904 & 0.791 & 1.195 & 0.637 & 0.156 & 0.567 & OK & OK & OK & si \\
\hline & & & & & & $\mathrm{OK}$ & 19 & 17 & 21 & 26 \\
\hline & & & & & & NOK & 11 & 13 & 9 & \\
\hline
\end{tabular}

Tabla 10. Evaluación de la significación y relevancia

Tal y como muestra la Tabla 10, de los 30 indicadores hay 26 que cumplen la significación y relevancia en al menos una de las muestras (once de ellos en todas las muestras, nueve en dos muestras y seis sólo en una de ellas). Los 4 indicadores que no cumplen la significación y la relevancia en ninguna de las muestras son: 
- 2 en el constructo de "remuneración”: REWvar034 (Participación en el capital de la compañía); REWvar035 (Remuneración flexible/pago en especie).

- 2 en el constructo de "participación": EMPp5q9 (Comités de consulta); EMPvar040 (Comités de empresa o negociación colectiva).

Del análisis de estos datos se deduce que todos los ítems de los constructos de "Comunicación” y "Formación" cumplen, en al menos una de las muestras, los criterios de significación y relevancia exigidos en un modelo formativo.

Por el contrario, los constructos de "Remuneración" y "Participación" tienen varios ítems que no cumplen los criterios de significación ni relevancia en ninguna de las muestras, lo que pone de manifiesto que estos ítems no son diferentes del resto de ítems del constructo.

Estos datos nos llevan a plantear para futuras investigaciones modificaciones en el modelo, que irían en la línea de lo apuntado por otros autores (Conci, 2012), que proponen crear varios constructos relacionados con remuneración y participación:

- En "Remuneración", reagrupar los ítems en "Recompensas para apoyar la participación” y "remuneración en función del rendimiento".

- En "Participación", distinguir entre "compartir la toma de decisiones" y "prácticas de rediseño de trabajo"

Tras evaluar el modelo de medida formativo de "HIWP", pasamos a continuación a evaluar el modelo de medida del constructo "performance" (ver Figura 1), que está configurado como un constructo de primer orden reflectivo con 10 indicadores (ver Anexo 1).

\subsubsection{Performance. Comprobación del modelo de medida. Etapa 1- Consistencia interna}

Para evaluar el modelo de medida del constructo performance Tras obtener el valor de la carga (outerloading) de los indicadores (Hair, Hult et al., 2013), que se muestra en la Tabla 11, se ha comprobado si es esta es superior a 0.708 (valores superiores a 0.6 son aceptables).

Del análisis de la Tabla 11 se puede comprobar que en la muestra de EEUU1999 todos los indicadores presentan consistencia interna, mientras que la muestra de España1997 es la que muestra más 
problemas, aunque sólo el indicador "PERFe210" ("Flexibilidad") no es aceptable. Estos problemas en la muestra de España son consistentes con los datos de estudios previos (Conci, 2012).

\begin{tabular}{|l|r|r|r|l|l|l|}
\cline { 2 - 7 } \multicolumn{1}{c|}{} & EEUU96 & EEUU99 & ESP97 & EEUU96 & EEUU99 & ESP97 \\
\hline PERFe210 <- 5PERF & 0.717 & 0.741 & 0.573 & OK & OK & NOK \\
\hline PERFe211 <- 5PERF & 0.688 & 0.724 & 0.657 & ACCEPT & OK & ACCEPT \\
\hline PERFvar157 <-5PERF & 0.813 & 0.826 & 0.732 & OK & OK & OK \\
\hline PERFvar158 <-5PERF & 0.786 & 0.839 & 0.735 & OK & OK & OK \\
\hline PERFvar159 <-5PERF & 0.75 & 0.788 & 0.652 & OK & OK & ACCET \\
\hline PERFvar160 <-5PERF & 0.765 & 0.827 & 0.711 & OK & OK & OK \\
\hline PERFvar161 <- 5PERF & 0.54 & 0.73 & 0.668 & NOK & OK & ACCEPT \\
\hline PERFvar163 <-5PERF & 0.771 & 0.837 & 0.737 & OK & OK & OK \\
\hline PERFvar164 <-5PERF & 0.704 & 0.765 & 0.668 & ACCEPT & OK & ACCEPT \\
\hline PERFvar165 <- 5PERF & 0.719 & 0.74 & 0.628 & OK & OK & ACCEPT \\
\hline
\end{tabular}

Tabla 11. Outerloading- Evaluación de la consistencia interna de los ítems de performance

\subsubsection{Performance. Comprobación del modelo de medida. Etapa 2- Fiabilidad del indicador}

Para evaluar la fiabilidad del constructo se evalúa la fialibilidad compuesta (compositereliability) tras un proceso de remuestreo (Bootstrapping). Tal y como muestra la Tabla 12, en todas las muestras es superior al criterio de aceptación de 0.708 .

\begin{tabular}{|l|r|r|r|l|l|l|}
\cline { 2 - 7 } \multicolumn{1}{c|}{} & EEUU96 & EEUU99 & ESP97 & EEUU96 & EEUU99 & ESP97 \\
\hline 5PERF & 0.918 & 0.940 & 0.894 & OK & OK & OK \\
\hline
\end{tabular}

Tabla 12. CompositeReliability- Evaluación de la fiabilidad del constructo de performance

\subsubsection{Performance. Comprobación del modelo de medida. Etapa 3 - Validez convergente}

En esta etapa se ha evaluado si el AVE es mayor que 0.5 en cada una de las muestras, tal y como muestra la Tabla 13.

\begin{tabular}{|l|r|r|r|l|l|l|}
\cline { 2 - 7 } \multicolumn{1}{c|}{} & EEUU96 & EEUU99 & ESP97 & EEUU96 & EEUU99 & ESP97 \\
\hline 5PERF & 0.531 & 0.613 & 0.459 & OK & OK & NOK \\
\hline
\end{tabular}

Tabla 13. AVE- Evaluación de la validez convergente del constructo de performance 


\subsubsection{Performance. Comprobación del modelo de medida. Etapa 4- Validez discriminante}

La validez discriminante del constructo se evalúa en dos etapas, y en cada una de ellas, como se muestra en la Tabla 14 y Tabla 15, se puede comprobar que las cargas del constructo performance son mayores que las del resto.

\begin{tabular}{|l|r|r|r|}
\cline { 2 - 4 } \multicolumn{1}{c|}{} & \multicolumn{1}{c|}{ EEUU96 } & EEUU99 & \multicolumn{1}{c|}{ ESP97 } \\
\hline 5PERF - 1INF & 0.195 & 0.259 & 0.289 \\
\hline 5PERF - 2TRA & 0.301 & 0.292 & 0.353 \\
\hline 5PERF - 3REW & 0.293 & 0.335 & 0.229 \\
\hline 5PERF - 4EMP & 0.407 & 0.443 & 0.297 \\
\hline 5PERF - 5PERF & 0.729 & 0.783 & 0.678 \\
\hline
\end{tabular}

Tabla 14. Evaluación de la validez discriminante - FORNELL-LACKER C.

\begin{tabular}{|l|r|r|r|r|r|}
\hline AÑO96 & \multicolumn{1}{|c|}{ 1INF } & \multicolumn{1}{c|}{ 2TRA } & \multicolumn{1}{c|}{ 3REW } & \multicolumn{1}{c|}{ 4EMP } & \multicolumn{1}{c|}{ 5PERF } \\
\hline PERFe210 & 0.142 & 0.214 & 0.222 & 0.267 & 0.717 \\
\hline PERFe211 & 0.144 & 0.183 & 0.235 & 0.28 & 0.688 \\
\hline PERFvar157 & 0.051 & 0.204 & 0.171 & 0.32 & 0.813 \\
\hline PERFvar158 & 0.106 & 0.264 & 0.23 & 0.327 & 0.786 \\
\hline PERFvar159 & 0.224 & 0.277 & 0.21 & 0.313 & 0.75 \\
\hline PERFvar160 & 0.158 & 0.243 & 0.202 & 0.343 & 0.765 \\
\hline PERFvar161 & 0.061 & -0.012 & 0.095 & 0.07 & 0.54 \\
\hline PERFvar163 & 0.182 & 0.241 & 0.259 & 0.339 & 0.771 \\
\hline PERFvar164 & 0.124 & 0.212 & 0.195 & 0.297 & 0.704 \\
\hline PERFvar165 & 0.193 & 0.222 & 0.266 & 0.278 & 0.719 \\
\hline
\end{tabular}

Tabla 15. Evaluación de la validez discriminante - - CROSS LOADINGS

\subsubsection{HIWP. Análisis del constructo de segundo orden}

Adicionalmente, y con objeto de evaluar el constructo de segundo orden HIWP, se muestran en la Tabla 16 los valores de la significatividad de los constructos de primer orden que conforman el constructo "HIWP".

\begin{tabular}{|l|r|r|r|}
\hline \multicolumn{1}{|c|}{ Constructo } & USA-1996 & USA-1999 & \multicolumn{1}{c|}{ España-1997 } \\
\hline COMUNICACIÓN - HIWP & 0.168 & 0.395 & 0.546 \\
\hline FORMACIÓN - HIWP & 0.659 & 0.921 & 2.422 \\
\hline REMUNERACIÓN - HIWP & 1.554 & 1.710 & 0.401 \\
\hline PARTICIPACIÓN - HIWP & 4.103 & 3.835 & 0.378 \\
\hline
\end{tabular}

Tabla 16. Evaluación de la significatividad (T-value) de los weight en el constructo de segundo orden 
Como se puede observar en esta tabla, la relación entre el constructo de "participación" y el constructo de segundo orden "HIWP" es significativa en las muestras de EEUU1996 y EEUU1999, la relación entre "Formación" y "HIWP" lo es sólo en la muestra ESPAÑA1997, y la relación entre "Remuneración” y "HIWP” sólo es significativa en la muestra de EEUU1999, mientras que la relación entre el constructo de "Comunicación" con "HIWP" no es significativa en ninguna de las tres muestras.

Estos resultados, sin embargo, no son concluyentes, dado que, por el modo en el que hemos definido el constructo de segundo orden (repetición de indicadores), la cantidad de ítems de cada constructo de primer orden afecta al peso en el constructo de segundo orden (Hair, Ringle et al., 2013). En nuestro caso existe una diferencia importante en el número de ítems: Comunicación tiene 5 ítems, Formación tiene 7, mientras que Remuneración y Participación tienen 9 ítems cada uno.

Este resultado deberá comprobarse en investigaciones futuras aplicando, en la definición del constructo de segundo orden HIWP, el método en dos etapas (Hair, Hult et al., 2013), para soslayar este inconveniente detectado al calcular la significatividad del constructo de segundo orden.

Aun teniendo en cuenta estos datos, en la Tabla 17 se muestran los valores del weight, y se han marcado los valores superiores a la media en cada una de las muestras.

\begin{tabular}{|l|r|r|r|}
\hline \multicolumn{1}{|c|}{ Constructo } & USA-1996 & USA-1999 & \multicolumn{1}{c|}{ Spain-1997 } \\
\hline COMUNICACIÓN - HIWP & 0.023 & 0.057 & 0.145 \\
\hline FORMACIÓN - HIWP & 0.112 & 0.151 & 0.722 \\
\hline REMUNERACIÓN - HIWP & 0.274 & 0.286 & 0.108 \\
\hline PARTICIPACIÓN - HIWP & 0.744 & 0.685 & 0.115 \\
\hline
\end{tabular}

Tabla 17. Evaluación de los pesos en el constructo de segundo orden

De esta tabla obtenemos que la mayor incidencia en los HIWP en el caso de las muestras de EEUU proviene del constructo "Participación", mientras que en el caso de España el constructo con mayor incidencia es el de "Formación", que además es el único constructo que es significativo en esta serie (ver Tabla 16). 


\subsection{Análisis de los resultados obtenidos en la comprobación del modelo de medida}

La evaluación de la calidad del instrumento de medida realizada en los apartados previos ha puesto de manifiesto:

- El constructo de performance sí que funciona como modelo reflectivo

- En cuanto al modelo de medida formativo de los cuatro constructos de primer orden que conforman los HIWP, los resultados obtenidos en la última etapa de comprobación ponen en duda la validez de algunos de los ítems de los constructos de remuneración y participación

- Sobre el constructo de segundo orden HIWP, se concluye que la metodología aplicada para su configuración (repetición de indicadores), nos impide obtener datos concluyentes sobre la significatividad de cada constructo de primer orden, por lo que en investigaciones futuras se deberá resolver este aspecto

Asumiendo que el modelo planteado en este trabajo necesita ajustes adicionales, que deberán ser abordados en investigaciones futuras, nos planteamos continuar con la evaluación del modelo de estructura para confirmar la conveniencia de realizar estos ajustes en el modelo de medida, de forma que se aumente la $\mathrm{R}^{2}$ explicada del modelo de estructura.

\subsection{Evaluación del modelo de estructura}

Siguiendo la recomendación de Hair, Ringle et al. (2013) se evalúa el modelo estructural: el poder predictivo, la relevancia predictiva y la significación de las relaciones estructurales, pero el primer paso es evaluar si existe colinealidad entre los constructos del modelo.

\subsubsection{Evaluación del modelo de estructura - Paso 1 - Evaluación de la colinealidad}

Aplicando la metodología descrita en los apartados previos, se ha comprobado que el valor del VIF de cada uno de los constructos y para cada una de las muestras, está por debajo de 5 , por lo que se puede confirmar la ausencia de colinealidad entre los diferentes constructos del modelo (Tabla 18). 


\begin{tabular}{|l|r|l|c|l|r|}
\hline \multicolumn{2}{|c|}{ USA-1996 } & \multicolumn{2}{c|}{ USA-1999 } & \multicolumn{2}{c|}{ España-1997 } \\
\hline \multicolumn{1}{|c|}{ Constructo } & VIF & \multicolumn{1}{c|}{ Constructo } & VIF & \multicolumn{1}{c|}{ Constructo } & VIF \\
\hline COMUNICACIÓN & 1.325 & COMUNICACIÓN & 1.492 & COMUNICACIÓN & 2.247 \\
\hline FORMACIÓN & 1.850 & FORMACIÓN & 1.565 & FORMACIÓN & 3.521 \\
\hline REMUNERACIÓN & 1.370 & REMUNERACIÓN & 1.406 & REMUNERACIÓN & 1.585 \\
\hline PARTICIPACIÓN & 1.797 & PARTICIPACIÓN & 1.721 & PARTICIPACIÓN & 2.718 \\
\hline
\end{tabular}

Tabla 18. Evaluación de la colinealidad en el modelo de estructura

\subsubsection{Evaluación del modelo de estructura - Paso 2 - Coeficientes path del modelo de estructura}

La significatividad del coeficiente path la obtenemos del estadístico $\mathrm{T}$, tras ejecutar el remuestreo Bootstrapping. Ver Tabla 19, Figura 3, Figura 4 y Figura 5.

\begin{tabular}{|c|r|r|r|}
\hline Constructo & EEUU1996 & EEUU1999 & \multicolumn{1}{|c|}{ España1997 } \\
\hline HIWP-PERFORMANCE & 9.066 & 10.594 & 4.734 \\
\hline
\end{tabular}

Tabla 19. Evaluación de la significatividad (T-value) del path-coefficient en el modelo de estructura

Estos datos ponen de manifiesto que es relevante la relación entre el constructo de segundo orden "HIWP" y la "performance" tal y como señala el cuerpo teórico existente al respecto, dado que el path entre el constructo de segundo orden y performance es significativo.

Evaluamos a continuación (Tabla 20) el valor del path-coefficient (efecto directo) entre el constructo de segundo orden HIWP y performance, que nos aporta información sobre la importancia relativa que tiene esa relación. Tal y como muestra la tabla, este dato es menor en la muestra de España que en las de EEUU. No obstante, todas ellas están en un mismo orden de magnitud manifestando una relación moderada-baja entre ambos constructos.

\begin{tabular}{|c|r|r|r|}
\hline Constructo & EEUU1996 & EEUU1999 & \multicolumn{1}{c|}{ España1997 } \\
\hline$H I W P-P E R F O R M A N C E$ & 0.454 & 0.536 & 0.399 \\
\hline
\end{tabular}

Tabla 20. Evaluación de los coeficientes path en el modelo de estructura 


\subsubsection{Evaluación del modelo de estructura - Paso 3 - Coeficiente de determinación $\left(\mathbf{R}^{2}\right.$ value}

Con esta etapa nos planteamos estimar qué cantidad de la varianza de los constructos dependientes, en este caso el constructo performance, es explicada por los constructos precedentes del modelo, a través del valor de $\mathrm{R}^{2}$.

El valor mínimo recomendado es del 10\%, y según Hair, Hult et al. (2013) valores por encima del 75\% nos aportarían una explicación sustancial, 50\% moderada, y a partir del 25\% débil.

Sobre el valor de $\mathrm{R}^{2}$ obtenido hay que resaltar (ver Tabla 21, Figura 6, Figura 7 y Figura 8):

- En las 3 muestras se ha detectado un efecto débil de las prácticas de HIWP sobre la performance medida.

- Se detecta un valor de varianza explicada mucho mayor en la muestra del año 1999-EEUU.

\begin{tabular}{|l|r|r|r|}
\cline { 2 - 4 } \multicolumn{1}{c|}{} & $\mathbf{R}^{2}$ - ANOO 96 & $\mathbf{R}^{2}$ - AÑO 99 & \multicolumn{1}{c|}{$\mathbf{R}^{2}$ - AÑO 97 } \\
\hline PERFORMANCE & 0.206 & 0.288 & 0.159 \\
\hline
\end{tabular}

Tabla 21. $\mathrm{R}^{2}$ de la variable dependiente (constructo "performance") para las tres muestras analizadas 


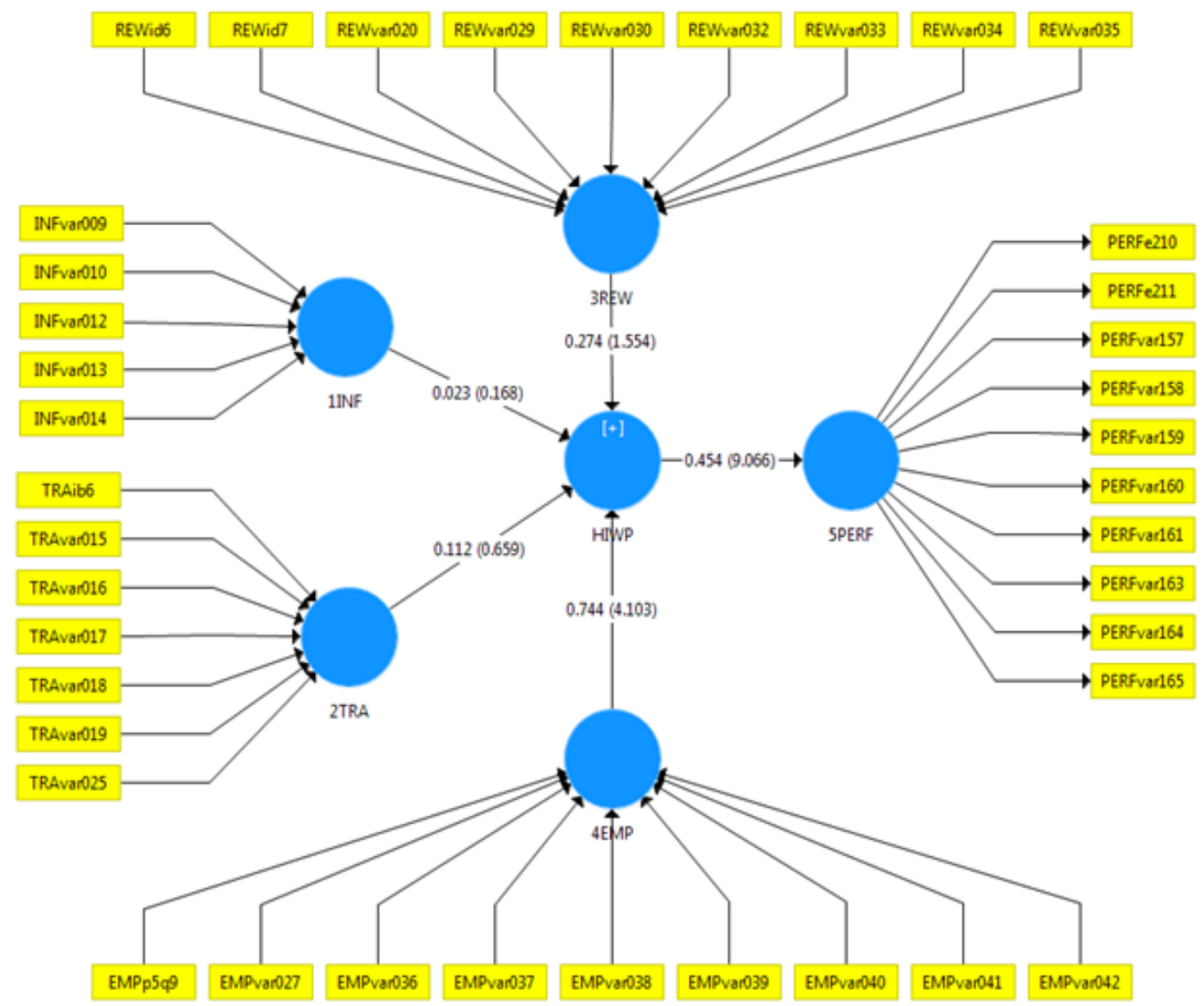

Figura 3. Muestra EEUU 1996. Significatividad (T-value) y pathcoefficient del modelo de estructura 


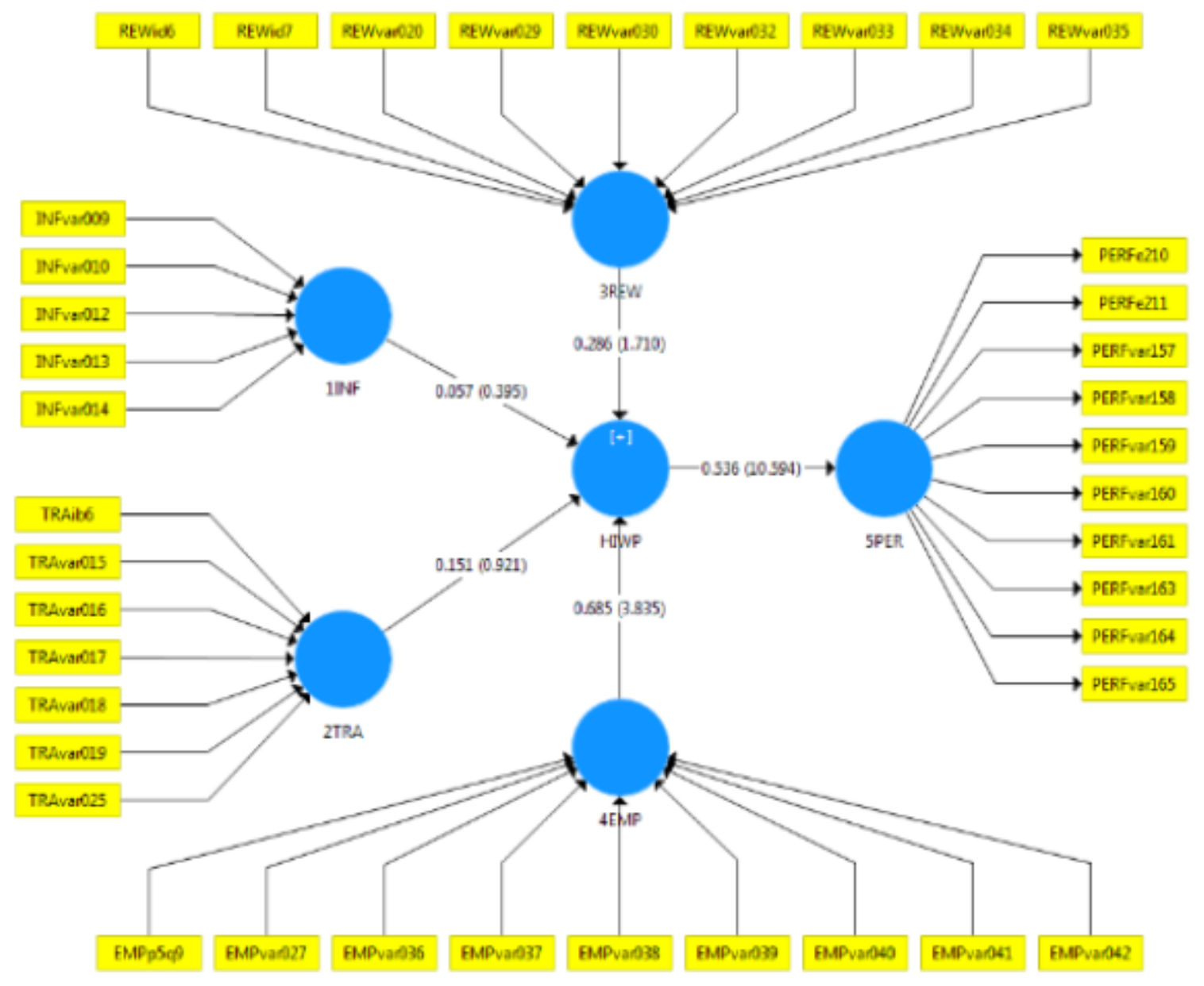

Figura 4. Muestra EEUU 1999. Significatividad (T-value) y pathcoefficient del modelo de estructura 


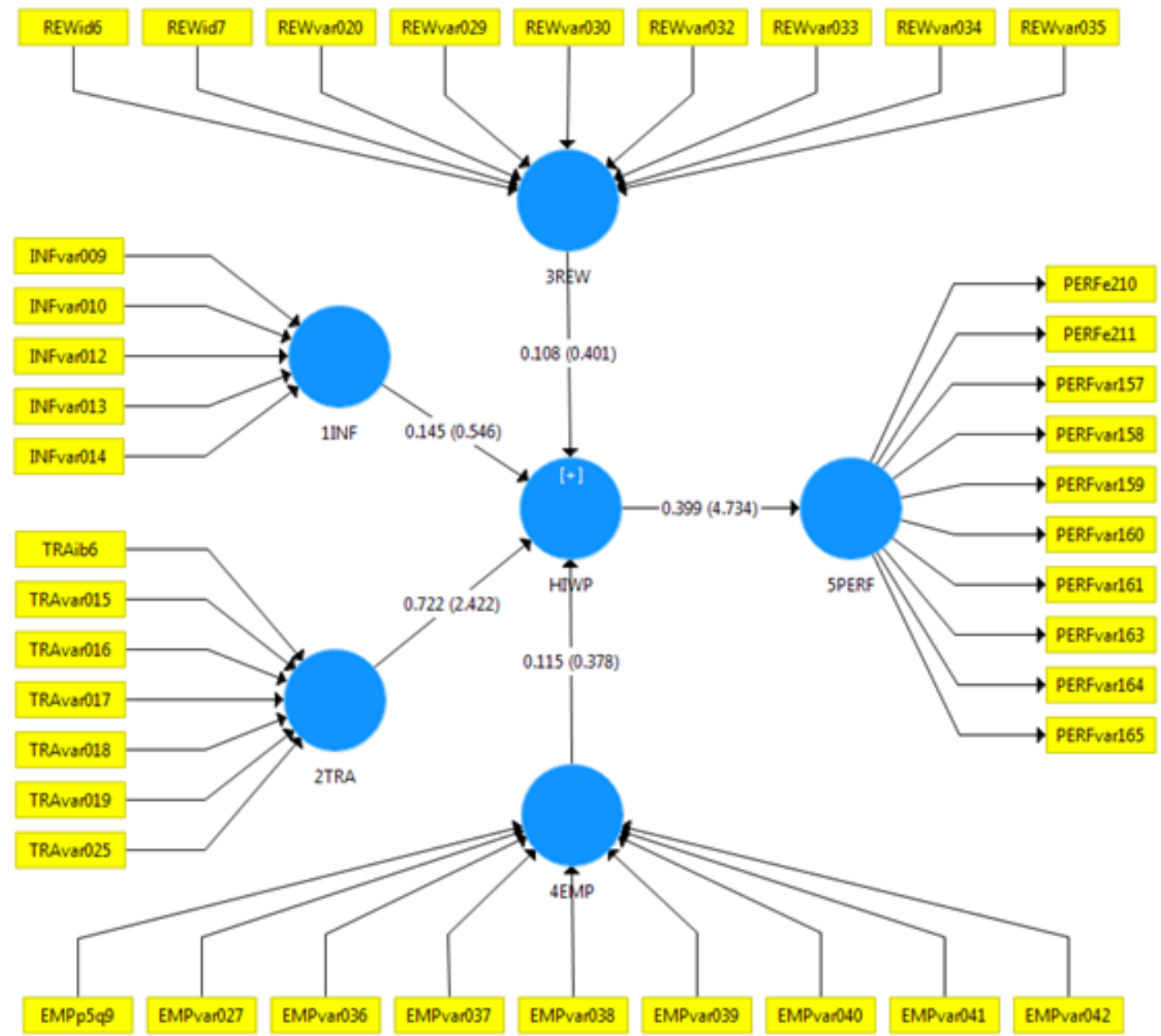

Figura 5. Muestra ESPAÑA 1997. Significatividad (T-value) y path del modelo de estructura 


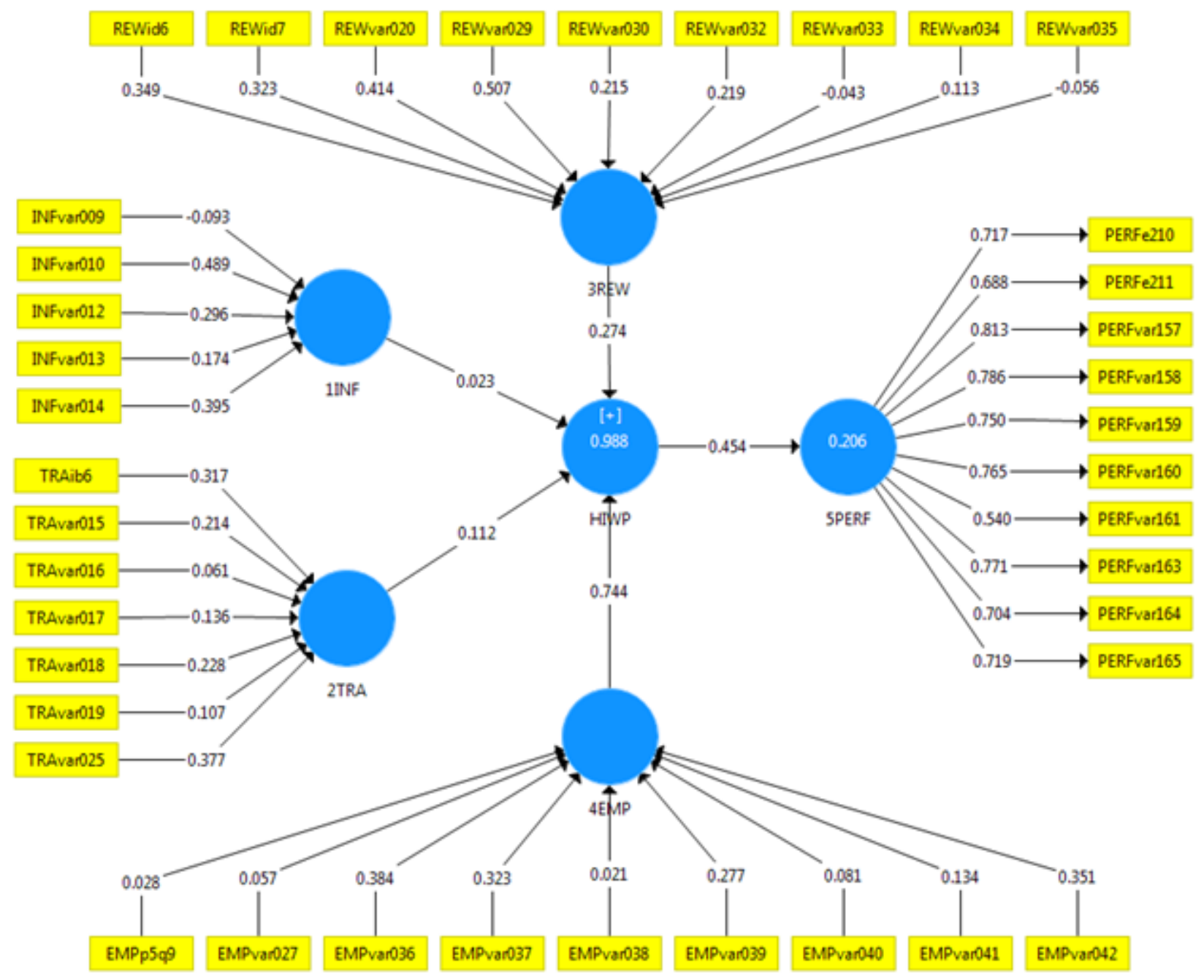

Figura 6. Muestra EEUU1996. Path del modelo de estructura y weights/loads del modelo de medida 


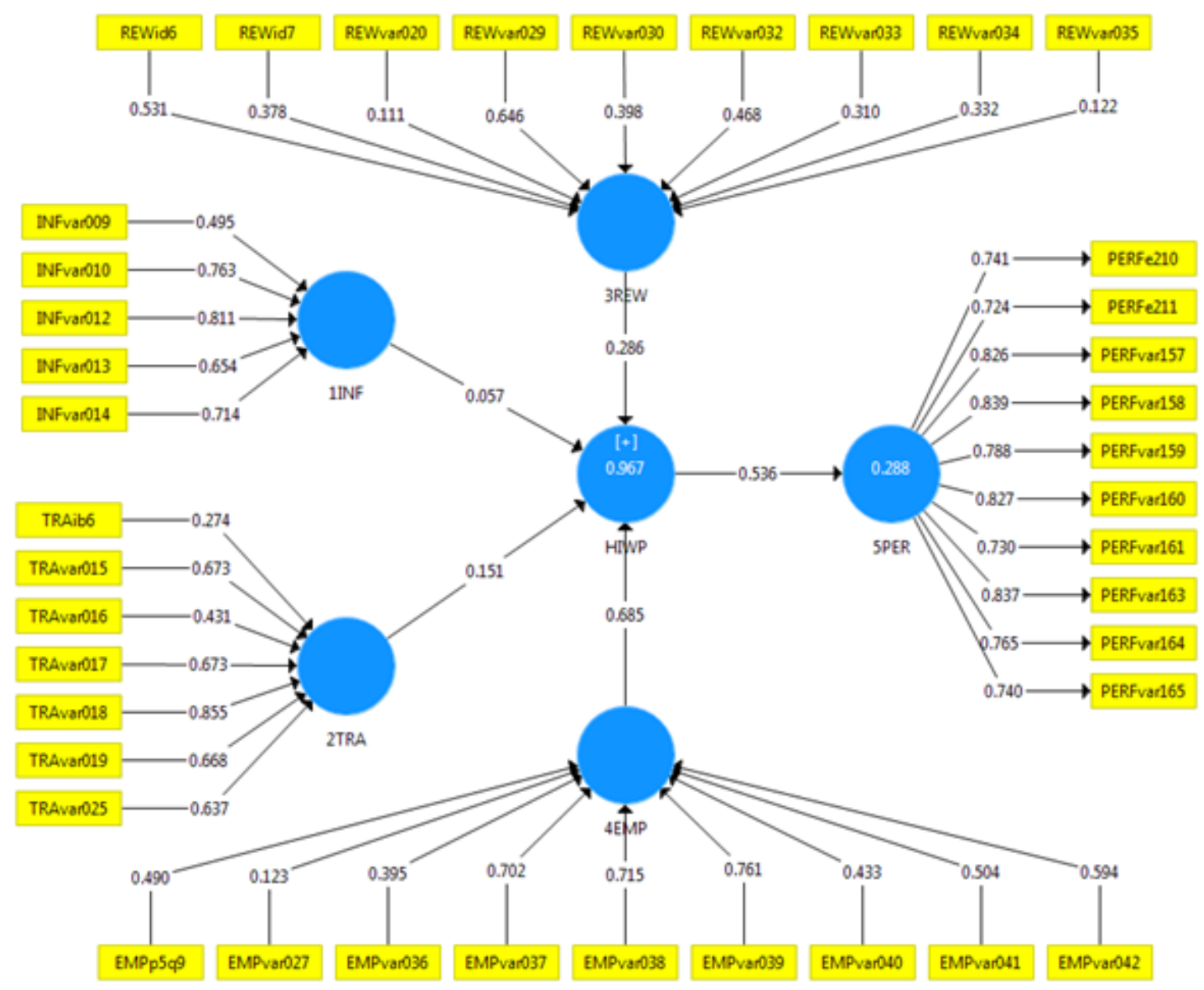

Figura 7. Muestra EEUU1999. Path del modelo de estructura y weights/loads del modelo de medida 


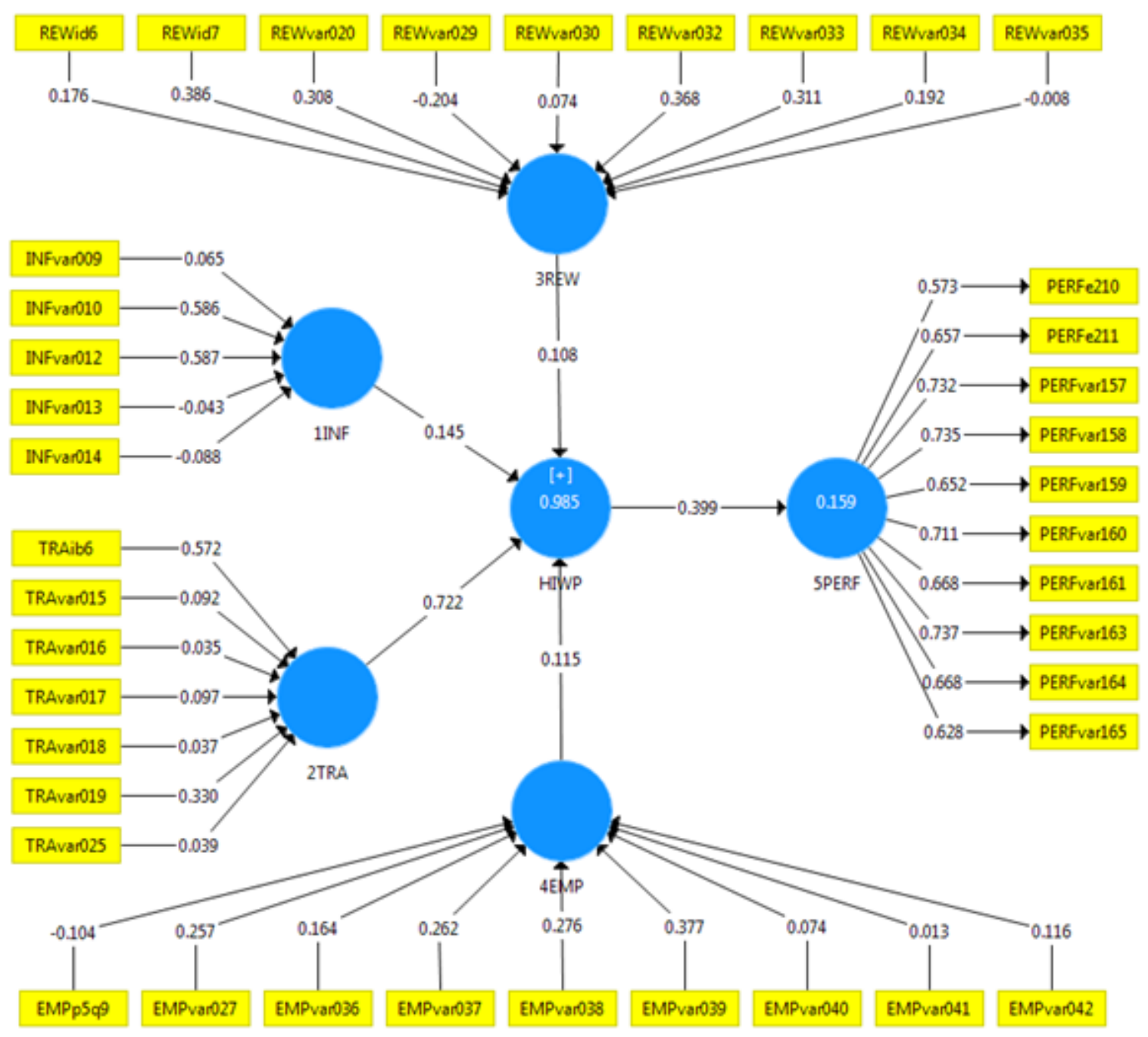

Figura 8. Muestra ESPAÑA 1997. Path del modelo de estructura y weights/loads del modelo de medida

Por otro lado, examinando los pesos de cada uno de los ítems en sus constructos de primer orden podemos identificar los programas que más efecto tienen para explicar la performance. Se han identificado en verde en la Tabla 22, marcando los pesos que están por encima de la media de los ítems de un constructo en cada muestra. 


\begin{tabular}{|c|c|c|c|c|c|c|c|c|c|c|c|c|}
\hline & \multicolumn{3}{|c|}{ 1INF } & \multicolumn{3}{|c|}{ 2TRA } & \multicolumn{3}{|c|}{ 3REW } & \multicolumn{3}{|c|}{ 4EMP } \\
\hline & 96 & 99 & 97 & 96 & 99 & 97 & 96 & 99 & 97 & 96 & 99 & 97 \\
\hline INFvar009 & -0.093 & -0.182 & 0.065 & & & & & & & & & \\
\hline INFvar010 & 0.489 & 0.513 & 0.586 & & & & & & & & & \\
\hline INFvar012 & 0.296 & 0.410 & 0.587 & & & & & & & & & \\
\hline INFvar013 & 0.174 & 0.109 & -0.043 & & & & & & & & & \\
\hline INFvar014 & 0.395 & 0.413 & -0.088 & & & & & & & & & \\
\hline TRAib6 & & & & 0.317 & -0.134 & 0.572 & & & & & & \\
\hline TRAvar015 & & & & 0.214 & -0.022 & 0.092 & & & & & & \\
\hline TRAvar016 & & & & 0.061 & -0.100 & 0.035 & & & & & & \\
\hline TRAvar017 & & & & 0.136 & 0.308 & 0.097 & & & & & & \\
\hline TRAvar018 & & & & 0.228 & 0.577 & 0.037 & & & & & & \\
\hline TRAvar019 & & & & 0.107 & 0.320 & 0.330 & & & & & & \\
\hline TRAvar025 & & & & 0.377 & 0.283 & 0.039 & & & & & & \\
\hline REWid6 & & & & & & & 0.349 & 0.417 & 0.176 & & & \\
\hline REWid7 & & & & & & & 0.323 & 0.305 & 0.386 & & & \\
\hline REWvar020 & & & & & & & 0.414 & 0.045 & 0.308 & & & \\
\hline REWvar029 & & & & & & & 0.507 & 0.612 & -0.204 & & & \\
\hline REWvar030 & & & & & & & 0.215 & 0.289 & 0.074 & & & \\
\hline REWvar032 & & & & & & & 0.219 & 0.282 & 0.368 & & & \\
\hline REWvar033 & & & & & & & -0.043 & -0.010 & 0.311 & & & \\
\hline REWvar034 & & & & & & & 0.113 & 0.116 & 0.192 & & & \\
\hline REWvar035 & & & & & & & -0.056 & -0.161 & -0.008 & & & \\
\hline EMPp5q9 & & & & & & & & & & 0.028 & 0.151 & -0.104 \\
\hline EMPvar027 & & & & & & & & & & 0.057 & -0.061 & 0.257 \\
\hline EMPvar036 & & & & & & & & & & 0.384 & 0.155 & 0.164 \\
\hline EMPvar037 & & & & & & & & & & 0.323 & 0.210 & 0.262 \\
\hline EMPvar038 & & & & & & & & & & 0.021 & 0.350 & 0.276 \\
\hline EMPvar039 & & & & & & & & & & 0.277 & 0.329 & 0.377 \\
\hline EMPvar040 & & & & & & & & & & 0.081 & 0.204 & 0.074 \\
\hline EMPvar041 & & & & & & & & & & 0.134 & 0.092 & 0.013 \\
\hline EMPvar042 & & & & & & & & & & 0.351 & 0.150 & 0.116 \\
\hline
\end{tabular}

Tabla 22. Pesos de los constructos

En resumen, respecto al análisis del modelo de estructura, hemos obtenido los siguientes resultados:

- Es significativo el coeficiente path entre los HIWP y la performance en las 3 muestras, aunque como el modelo de medida no se ha podido validar de forma completa, este resultado no es concluyente.

- En las muestras de EEUU el constructo que tiene más importancia relativa para conformar el constructo de HIWP es "Participación", mientras que en la muestra de España es el de "Formación".

- Sobre las prácticas individuales que tienen más incidencia en la performance: 
- En "Comunicación": INFvar010 (información sobre Resultados del departamento) e INFvar012 (Información sobre nuevas tecnologías)

- En "Formación”: En el caso de EEUU destacan TRAvar018 (Análisis estadístico/calidad) y TRAvar025 (Formación para otras áreas o puestos de la empresa), mientras que en España destacan TRAib6 (Entrenamiento en las habilidades para su propio trabajo) y TRAvar019 (Formación de equipos de trabajo)

- En "Remuneración”: REWid7 (Recompensas no monetarias)

- En "Participación": EMPvar037 (Enriquecimiento o rediseño del puesto de trabajo) y EMPvar039 (Otros grupos de sugerencias diferentes de círculos de calidad)

- Respecto a qué cantidad de la varianza de performance, es explicada por el uso de HIWP, hemos encontrado una relación débil en las muestras de EEUU $(>0.2)$, mientras que en la muestra de España la relación es muy baja (0.16).

\section{Conclusiones, limitaciones e investigación futura}

Los objetivos de este trabajo se centraban en comprobar el modelo de medida de los HIWP del cuestionario de Lawler (Lawler III, 1986) como modelo formativo, para posteriormente analizar su capacidad predictiva.

Respecto al primer objetivo, desde un punto de vista académico con este trabajo hemos comprobado que la escala de medida de un constructo de segundo orden para las "HIWP", no es del todo adecuada. El principal problema se plantea en dos de los constructos de primer orden, por lo que se plantea como investigación futura, mejorar las escalas de remuneración y participación, dividiendo cada uno de los constructos, concebidos originalmente como unidimensionales, en dos sub-constructos más homogéneos. Además, en esa investigación deberá plantearse la configuración del constructo de segundo orden aplicando el método de las dos etapas, en lugar del método de repetición de los ítems que se ha aplicado en este estudio.

Por otro lado, en relación con el segundo objetivo, nuestro estudio confirma la relación significativa, aunque baja, entre el uso de los HIWP y los resultados en la empresa, que en nuestro modelo se miden a través de resultados percibidos. Aunque la existencia de esta relación, que parte de un modelo de 
medida que a nivel metodológico no se ha validado completamente, debe confirmarse en investigaciones futuras.

De ser así, y confirmarse definitivamente esta relación, el hallazgo es importante para el entorno profesional, ya que cuantifica la relación entre el uso de los HIWP y la performance en dos países con importantes diferencias culturales, y además identifica las prácticas que contribuyen en mayor medida a esta relación positiva.

En general, este trabajo contribuye al debate que gira en torno a la relación HIWP-resultados, apuntando a una posible capacidad predictiva del modelo de Lawler para medir el efecto del uso de los HIWP sobre los resultados de las empresas, partiendo de un modelo de medida que presenta relaciones formativas.

Estas contribuciones deben considerarse teniendo en cuenta las limitaciones de la investigación. En primer lugar, nuestros datos provienen de estudios de hace más de 15 años, aunque para probar los modelos de medida la vigencia de los datos no es una limitación importante puesto que analizamos la relación entre los constructos y no nos interesa describir el estado de evolución de estas prácticas, sino cómo poder medir esta relación definida.

Por otra parte, sólo disponemos de datos de empresas grandes de dos países por lo que no podemos generalizar las conclusiones a otros contextos. Además, los datos utilizados provienen de investigaciones de carácter transversal, lo que puede provocar que no se recojan algunos efectos derivados del uso de HIWP que, al diferirse en el tiempo, son importantes para la generación de resultados. Por último, el hecho de que las respuestas al cuestionario provenga de una única fuente de información (el directivo), en lugar de preguntar a más informantes por empresa, puede suponer, tal y como han propuesto algunos autores (Bowen \& Ostroff, 2004; Guest, 2011; Nishii, Lepak, \& Schneider, 2008; Paul \& Anantharaman, 2003) una limitación en la validez de las conclusiones alcanzadas.

Las propuestas de líneas de investigación futuras tienen, en su mayor parte, una relación directa con las limitaciones señaladas anteriormente. Así, en primer lugar, sería interesante mejorar el modelo inicial en las escalas de remuneración y participación, dividiendo los constructos concebidos originalmente como unidimensionales, en dos constructos más homogéneos, y volver a comprobar la validez del mismo. Respecto a la transculturalidad del modelo, realizar un análisis multigrupo nos permitiría determinar si el modelo de medida es lo suficientemente consistente para ser utilizado en diferentes contextos 
culturales, y por último, el desarrollo de investigaciones de carácter longitudinal es un reto importante en el ámbito de los HIWP.

\section{Referencias}

Arthur, J.B. (1994). Effects of human resource systems on manufacturing performance and turnover. Academy of management Journal, 37(3), 670-687. Retrieved from: http://search.ebscohost.com/login.aspx? direct $=$ true $\& \mathrm{db}=$ buh\&AN=9412131793\&site=ehost-live\&scope=site $\mathrm{http}: / / \mathrm{dx} \cdot \operatorname{doi}$. org $/ 10.2307 / 256705$

Barroso Castro, M.C., Cepeda Carrión, G.A., \& Roldán Salgueiro, J.L. (2007). Constructos latentes y agregados en la economía de la empresa. Asociación Española de Dirección y Economía de la Empresa (AEDEM). Retrieved from: http://dialnet.unirioja.es/servlet/oaiart? $\operatorname{codigo}_{0}=2487672$

Becker, B.E., \& Huselid, M.A. (2006). Strategic human resources management: Where do we go from here?. Journal of management, 32(6), 898-925. http://dx.doi.org/10.1177/0149206306293668

Benson, G.S., Young, S.M., \& Lawler III, E.E. (2006). High-involvement work practices and analysts' forecasts of corporate earnings. Human resource management, 45(4), 519-537. Retrieved from Wiley Subscription Services, Inc., A Wiley Company. http://dx.doi.org/10.1002/hrm.20130

Boselie, P., Dietz, G., \& Boon, C. (2005). Commonalities and contradictions in HRM and performance research. Human Resource Management Journal, 15(3), 67-94. Retrieved from Wiley-Blackwell: http://search.ebscohost.com/login.aspx?direct $=$ true $\& \mathrm{db}=$ buh\&AN=17649112\&site=ehost-live\&scope $=$ site http://dx.doi.org/10.1111/j.1748-8583.2005.tb00154.x

Bowen, D.E., \& Ostroff, C. (2004). Understanding HRM-Firm Performance Linkages: The Role of the "Strengt" of the HRM System. Academy of Management Review, 29(2), 203-221. Retrieved from: http://amr.aom.org/content/29/2/203.abstract

Boxall, P. (2012). High-performance work systems: What, why, how and for whom?. Asia Pacific Journal of Human Resources, 50(2), 169-186. http://dx.doi.org/10.1111/j.1744-7941.2011.00012.x

Camps, J., \& Luna-Arocas, R. (2009). High involvement work practices and firm performance. International journal of buman resource management, 20(5), 1056-1077. Retrieved from Routledge: http://search.ebscohost.com/login.aspx?direct=true\&db=buh\&AN=40628014\&site=ehost-live\&scope=site http://dx.doi.org/10.1080/09585190902850273

Cappelli, P., \& Neumark, D. (2001). Do "High-Performance" Work Practices Improve EstablishmentLevel Outcomes?. Industrial \& Labor Relations Review, 54(4), 737-775. Retrieved from: http://ilr.sagepub.com/content/54/4/737.abstract http://dx.doi.org/10.1177/001979390105400401 
Cepeda, G., \& Roldán, J.L. (2004). Aplicando en la práctica la técnica PLS en la administración de empresas. Conocimiento y Competitividad. XIV Congreso Nacional ACEDE.Murcia (pp. 74-78).

Combs, J., Liu, Y.M., Hall, A., \& Ketchen, D. (2006). How much do high-performance work practices matter? A meta-analysis of their effects on organizational performance. Personnel psychology, 59(3), 501-528. http://dx.doi.org/10.1111/j.1744-6570.2006.00045.x

Conci, G. (2012). Perceived results obtained by companies associated to the use of high involvement work practices (HIWP). Working Papers on Operations Management, 3(1), 01-15. Retrieved from: http://ojs.upv.es/index.php/WPOM/article/view/1065 http://dx.doi.org/10.4995/wpom.v3i1.1065

Coye, R.W., \& Belohlav, J.A. (1995). An Exploratory Analysis of Employee Participation. Group \& Organization Management, 20(1), 4-17. Retrieved from: http://gom.sagepub.com/content/20/1/4.abstract http://dx.doi.org/10.1177/1059601195201002

Datta, D.K., Guthrie, J.P., \& Wright, P.M. (2005). Human Resource Management and Labor Productivity: Does Industry Matter?. Academy of management Journal, 48(1), 135-145. Retrieved from: http://amj.aom.org/content/48/1/135.abstract http://dx.doi.org/10.5465/AMJ.2005.15993158

Drehmer, D.E., Belohlav, J.A., \& Coye, R.W. (2000). An Exploration of Employee Participation Using a Scaling Approach. Group \& Organization Management, 25(4), 397-418. Retrieved from: http://gom.sagepub.com/content/25/4/397.abstract http://dx.doi.org/10.1177/1059601100254005

Ericksen, J.E.F. (2007). High performance work systems, dynamic workforce alignment, and firm performance. Academy of Management Annual Meeting Proceedings (pp. 1-6) Academy of Management. http://dx.doi.org/10.5465/AMBPP.2007.26518272

Guerrero, S., \& Barraud-Didier, V. (2004). High-involvement practices and performance of French firms. International journal of buman resource management, 15(8), 1408-1423. http://dx.doi.org/10.1080/0958519042000258002

Guest, D.E. (2011). Human resource management and performance: still searching for some answers. Human Resource Management Journal, 21(1), 3-13. Retrieved from Blackwell Publishing Ltd. http://dx.doi.org/10.1111/j.1748-8583.2010.00164.x

Guthrie, J.P. (2001). High-involvement work practices, turnover, and productivity: Evidence from New Zealand. Academy of management Journal, 44(1), 180-190. http://dx.doi.org/10.2307/3069345

Guthrie, J.P., Spell, C.S., \& Nyamori, R.O. (2002). Correlates and consequences of high involvement work practices: The role of competitive strategy. International journal of buman resource management, 13(1), 183-197. http://dx.doi.org/10.1080/09585190110085071 
Hair, J.F. Jr., Hult, G.T.M., Ringle, C., \& Sarstedt, M. (2013). A Primer on Partial Least Squares Structural Equation Modeling (PLS-SEM). Thousand Oaks: Sage Publishing. ISBN 9781452217444

Hair, J., Ringle, C.M., \& Sarstedt, M. (2013). Partial Least Squares Structural Equation Modeling: Rigorous Applications, Better Results and Higher Acceptance. Long Range Planning, 46(1GÇô2), 1-12. Retrieved from: http://www.sciencedirect.com/science/article/pii/S0024630113000022 http://dx.doi.org/10.1016/j.lrp.2013.01.001

Huselid, M.A. (1995). The impact of human-resource management-practices on turnover, productivity, and corporate financial performance. Academy of management Journal, 38(3), 635-672. http://dx.doi.org/10.2307/256741

Huselid, M.A., \& Becker, B.E. (1996). Methodological issues in cross-sectional and panel estimates of the human resource-firm performance link. Industrial relations, 35(3), 400-422. http://dx.doi.org/10.1111/j.1468-232x.1996.tb00413.x

Jarvis, C., Mackenzie, S., \& Podsakoff, P. (2003). A Critical Review of Construct Indicators and Measurement Model Misspecification in Marketing and Consumer Research. Journal of Consumer Research, 30(2), 199-218. http://dx.doi.org/10.1086/376806

Jiang, K., Lepak, D.P., Hu, J., \& Baer, J.C. (2012). How Does Human Resource Management Influence Organizational Outcomes? A Meta-analytic Investigation of Mediating Mechanisms. Academy of management Journal, 55(6), 1264-1294. Retrieved from: http://ami.aom.org/content/55/6/1264.abstract http://dx.doi.org/10.5465/amj.2011.0088

Jiang, K., Takeuchi, R., \& Lepak, D.P. (2013). Where do We Go From Here? New Perspectives on the Black Box in Strategic Human Resource Management Research. Journal of management studies, 50(8), 1448-1480. http://dx.doi.org/10.1111/joms.12057

Lawler III, E.E. (1986). High-Involvement Management. Participative Strategies for Improving Organizational Performance. Jossey-Bass Inc., Publishers.

Lawler, E.E. (2005). From human resource management to organizational effectiveness. Human resource management, 44(2), 165-169. Retrieved from Wiley Subscription Services, Inc., A Wiley Company. http://dx.doi.org/10.1002/hrm.20059

Lawler III, E.E., Mohrman, S., \& Benson, G. (2001). Organizing for high performance: Employee involvement, TQM, reengineering, and knowledge management in the fortune 1000. The CEO report Jossey-Bass.

Lawler III, E.E., Mohrman, S., \& Ledford, G. (1998). Strategies for high performance organizations: Employee involvement, TQM, and reengineering programs in fortune 1000 coporations. Jossey-Bass. 
Marin-Garcia, J.A., Bonavía Martín, T., \& Miralles Insa, C. (2008). The use of employee participation in the USA and Spanish companies. International Journal of Management Scienceand Engineering Management, 3(1), 71-80. Retrieved from: http://www.worldacademicunion.com/journal/MSEM/online.htm

Marin-Garcia, J.A. (2013). ¿Qué sabemos sobre la relación de los programas de recursos humanos de alto rendimiento y el desempeño organizativo? (What do we know about the relationship between High Involvement Work Practices and Performance? WPOM - Working Papers On Operations Management, 4(2), 01-15. http://dx.doi.org/10.4995/wpom.v4i2.1552. Retrieved from: http://ojs.upv.es/index.php/WPOM/article/view/1552

Marin-Garcia, J.A., \& Conci, G. (2009). Exploratory study of high involvement work practices: Identification of the dimensions and proposal of questionnaire to measure the degree of use in the company. Intangible Capital, 5(3), 278-300. http://dx.doi.org/10.3926/ic.2009.v5n3.p278-300

Marin-Garcia, J.A., \& Conci, G. (2010). Análisis factorial exploratorio para identificar las dimensiones subyacentes de los constructos de remuneración y participación. Working Papers on Operations Management, 1(1), 46-55. http://dx.doi.org/10.4995/wpom.v1i1.795

Marin-Garcia, J.A., \& Conci, G. (2012). Verification of the reflective model of first order factors for reward and empowerment constructs based on questionnaires derived from Lawler et al. (1991). Journal of Industrial Engineering and Management, 5(2), 473-495. http://dx.doi.org/10.3926/jiem.454

Marin-Garcia, J.A., \& Conci, G. (2013). Validación de un cuestionario para medir el grado de uso de las prácticas de alta implicación de los trabajadores. Intangible capital, 9(3), 854-882. Retrieved from: http://www.raco.cat/index.php/Intangible/article/view/273491

Nishii, L.H., Lepak, D.P., \& Schneider, B. (2008). Employee attributions of the "why" of HR practices: Their effects on employee attitudes and behaviors, and customer satisfaction. Personnel Psychology, 61(3), 503-545. http://dx.doi.org/10.1111/j.1744-6570.2008.00121.x. Retrieved from: http://www.scopus.com/inward/record.url?eid=2-s2.049149130883\&partnerID $=40 \& \mathrm{md} 5=\mathrm{b} 3 e e f 8 \mathrm{~b} 1 \mathrm{cdffac} 81 \mathrm{f} 10451 \mathrm{~d} 18217639 \mathrm{~b}$

Paul, A.K., \& Anantharaman, R.N. (2003). Impact of people management practices on organizational performance: Analysis of a causal model. International journal of buman resource management, 14(7), 1246-1266. http://dx.doi.org/10.1080/0958519032000145648. Retrieved from Routledge: http://search.ebscohost.com/login.aspx?direct $=$ true\&db=buh\&AN=10917483\&site=ehost-live\&scope $=$ site

Ringle, C.M., Wende, S., \& Becker, J.-M. (2015). SmartPLS 3.2.3 (Version 3.2.3). Retrieved from: http://www.smartpls.com 
Subramony, M. (2009). A meta-analytic investigation of the relationship between HRM bundles and firm performance. Human resource management, 48(5), 745-768. Retrieved from: http://search.ebscohost.com/login.aspx?direct=true\&db=buh\&AN=44435603\&site=ehost-live\&scope=site http:/ /dx.doi.org/10.1002/hrm.20315

Wright, P.M., Gardner, T.M., Moynihan, L.M., \& Allen, M.R. (2005). The relationship between HR practices and firm performance: Examining causal order. Personnel psychology, 58(2), 409-446. http://dx.doi.org/10.1111/j.1744-6570.2005.00487.x

Yu, C., Finegold, D., Lawler, E., \& Cochran, D. (2000). Does cultural fit matter? The adoption and effectiveness of employee involvement practices in China and the United States. Current Topics In Management, 5, 283-304.

Zheng, C., Morrison, M., \& O'Neill, G. (2006). An empirical study of high performance HRM practices in Chinese SMEs. International journal of buman resource management, 17(10), 1772-1803. http://dx.doi.org/10.1080/09585190600965282. Retrieved from Routledge: http://search.ebscohost.com/login.aspx?direct $=$ true\&db=buh\&AN $=22832862 \&$ site $=$ ehost-live\&scope $=$ site

\section{ANEXO 1: Indicadores utilizados para medir los constructos}

\begin{tabular}{|c|c|}
\hline $\begin{array}{l}\text { Indique cuántos de los trabajadores de su empresa están } \\
\text { en la actualidad participando directamente en cada uno } \\
\text { de los siguientes programas: }\end{array}$ & $\begin{array}{l}\text { About how many of your corporation's employees are } \\
\text { currently involved in each of the following activities } \\
\text { or programs? }\end{array}$ \\
\hline EMPp5q9 Comités de consulta & Emp committee concerned with policy and/or stategy \\
\hline Sistemas de sugerencias individuales & Suggestion system \\
\hline Encuestas de opinión & Survey feedback \\
\hline $\begin{array}{l}\text { EMPvar037 Enriquecimiento o rediseño del puesto de } \\
\text { trabajo }\end{array}$ & Job enrichment or redesign \\
\hline EMPvar038 Círculos de Calidad & Quality circles \\
\hline $\begin{array}{l}\text { EMPvar039 Otros grupos de sugerencias diferentes de } \\
\text { Círculos de Calidad }\end{array}$ & Employee participation groups other than quality circles \\
\hline EMPvar040 Comités de empresa o negociación colectiva. & Union-management QWL committees \\
\hline Mini-empresas & Mini-business units \\
\hline Grupos de trabajo semiautónomo & Self-managing workteams \\
\hline $\begin{array}{l}\text { ¿Cuántos de los trabajadores de la empresa reciben de } \\
\text { forma habitual información sobre...? }\end{array}$ & $\begin{array}{l}\text { About how many corporation employees are routinely } \\
\text { provided with the following types of information? }\end{array}$ \\
\hline INFvar009 Resultados operativos globales de la empresa & Info on corps overall operating results \\
\hline Resultados del departamento & Info on units operating results \\
\hline Nuevas tecnologías que pueden afectarles. & Advance info on new technologies \\
\hline Objetivos y planes del negocio & Info on business plans/goals \\
\hline $\begin{array}{l}\text { INFvar014 Comparación con el desempeño de la } \\
\text { competencia }\end{array}$ & Info on competitors' relative performance \\
\hline
\end{tabular}




\begin{tabular}{|c|c|}
\hline $\begin{array}{l}\text { Indique a cuántos de los trabajadores de la empresa se } \\
\text { les aplica cada uno de estos sistemas de remuneración o } \\
\text { recompensa: }\end{array}$ & $\begin{array}{l}\text { About how many employees are covered by a } \\
\text { pay/reward system with each of the following } \\
\text { elements? }\end{array}$ \\
\hline $\begin{array}{l}\text { REWid6 } \\
\text { de grupo }\end{array}$ & Work Group or Team incentive \\
\hline Recompensas no monetarias & Non-monetary awards for performance \\
\hline REWvar020 Seguridad en el empleo & Employment security \\
\hline $\begin{array}{l}\text { REWvar029 Complemento de sueldo en función de las } \\
\text { habilidades y conocimientos del trabajador }\end{array}$ & Knowledge/SBP \\
\hline REWvar030 Reparto de beneficios de la empresa & Profit sharing \\
\hline $\begin{array}{l}\text { REWvar032 Reparto de ganancias por sugerencias } \\
\text { aportadas }\end{array}$ & Gain sharing \\
\hline $\begin{array}{l}\text { REWvar033 Complemento por logro de metas u objetivos } \\
\text { individuales }\end{array}$ & Individual incentive \\
\hline Participación en el capital de la compañía & Stock option plan \\
\hline Remuneración flexible/pago en especie & Flexible cafeteria-style benefits \\
\hline $\begin{array}{l}\text { ¿Cuántos de sus trabajadores han recibido, en los } \\
\text { últimos } 3 \text { años, formación sistemática y programada } \\
\text { en ...? }\end{array}$ & $\begin{array}{l}\text { About how many corporation employees have } \\
\text { received, within the past } 3 \text { years, systematic, formal } \\
\text { training on the following } \\
\text { types of skills? }\end{array}$ \\
\hline $\begin{array}{l}\text { TRAib6 Entrenamiento en las habilidades de su propio } \\
\text { trabajo }\end{array}$ & Training in job skills training \\
\hline $\begin{array}{l}\text { TRAvar015 Toma de decisiones/solución de problemas en } \\
\text { grupos }\end{array}$ & Training in group decision-making/problem-solving skills \\
\hline TRAvar016 Conocimientos de liderazgo & Training in leadership skills \\
\hline TRAvar017 Conocimientos de administración de empresas & Training in skills understanding the business \\
\hline TRAvar018 Análisis estadístico/calidad & Training in quality/statistical analysis skills \\
\hline TRAvar019 Formación de equipos de trabajo & Training in team building skills \\
\hline $\begin{array}{l}\text { TRAvar025 Formación para otras áreas o puestos de trabajo } \\
\text { de la.empresa }\end{array}$ & Training in cross training \\
\hline $\begin{array}{l}\text { ¿Cómo valora el impacto positivo o negativo, si existe, } \\
\text { que tienen los esfuerzos para lograr la implicación del } \\
\text { trabajador en los siguientes indicadores del rendimiento } \\
\text { de la empresa? }\end{array}$ & $\begin{array}{l}\text { How much of a negative or positive impact, if either, } \\
\text { have employee involvement efforts had on each of the } \\
\text { following performance indicators in your } \\
\text { corporation? }\end{array}$ \\
\hline Flexibilidad & Speed/flexibility \\
\hline Lealtad del trabajador & employee loyalty \\
\hline PERFvar157 Productividad & productivity \\
\hline PERFvar158 Calidad de los productos/servicios & quality of product or service \\
\hline PERFvar159 Atención al cliente & customer service \\
\hline PERFvar160 Satisfacción del trabajador & employee satisfaction \\
\hline PERFvar161 Rotación del personal & turnover \\
\hline PERFvar163 Competitividad & competitiveness \\
\hline PERFvar164 Beneficios & profitability \\
\hline PERFvar165 Calidad de vida en el trabajo & employee QWL \\
\hline
\end{tabular}

Article's contents are provided on an Attribution-Non Commercial 3.0 Creative commons license. Readers are allowed to copy, distribute and communicate article's contents, provided the author's and Intangible Capital's names are included. It must not be used for commercial purposes. To see the complete license contents, please visit http://creativecommons.org/licenses/by-nc/3.0/. 